\title{
Geology and Beryl Deposits
}

of the Peerless Pegmatite

Pennington County

South Dakota

GEOLOGICAL SURVEY PROFESSIONAL PAPER 297-A

This report concerns work done partly on behalf

of the U.S. Atomic Energy Commission

and is published with the permission of the

Commission

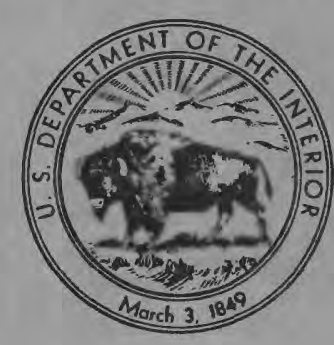





\section{Geology and Beryl Deposits}

of the Peerless Pegmatite

Pennington County

South Dakota

By DOUGLAS M. SHERIDAN, HAL G. STEPHENS, MORTIMER H. STAATZ and JAMES J. NORTON

PEGMATITES AND OTHER PRECAMBRIAN ROCKS IN THE SOUTHERN BLACK HILLS

GEOLOGICAL SURVEY PROFESIONAL PAPER 297-A

This report concerns work done partly on behalf

of the U.S. Atomic Energy Commission

and is published with the permission of the

Commission

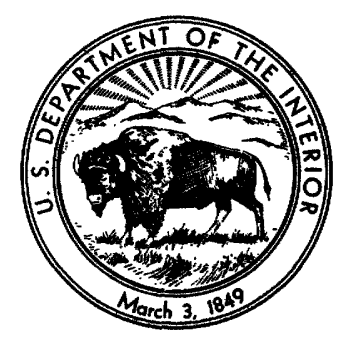

UNITED STATES GOVERNMENT PRINTING OFFICE, WASHINGTON : 1957 


\section{UNITED STATES DEPARTMENT OF THE INTERIOR}

FRED A. SEATON, Secretary

\section{GEOLOGIGAL SURVEY}

Thomas B. Nolan, Director

For sale by the Superintendent of Documents, U. S. Government Printing Office Washington 25, D. C. - Price $\$ 1.50$ (paper cover) 


\section{CONTENTS}

Abstract

Introduction

Location

History and production

Past and present investigations

Acknowledgments

Mine workings

Geology -

Metamorphic rocks

Quartz-plagioclase-muscovite pegmatite, undiffer-

entiated .............

Peerless pegmatite

Size, shape, and structure

Internal units

Variation in mica composition

Faults
Page

1

1

3

4
Geology-Continued Peerless pegmatite-Continued

Chemical composition

Origin

Mineral deposits

Lithia mica

Beryl.......

Potash feldspar.............

Seda feldspar.......................

Amblygonite-montebrasite . ...

Other minerals . . . . . .

Reserves_..-1.2.

Literature cited

Logs of U. S. Bureau of Mines diamond-drill holes......

Index . . . . . . . .
Page

17

21

21

21

23

24

24

24

25

45

\section{ILLUSTRATIONS}

[Plates 4-7 in pocket]

Plate 1. Wall rock, Peerless pegmatite. A, Quartz-mica schist containing staurolite partially changed to muscovite, chlorite (ripidolite), quartz, and biotite. $B$, Schist in which staurolite has been completely replaced by muscovite, quartz, and biotite. $C$ and $D$, Tourmalinized schist. $E$, Pseudomorph of a staurolite crystal_._. Facing

2. Peerless pegmatite. $A$, The main axis of Peerless pegmatite. $B$, Layers in the wall zone...................

3. Wall zone, Peerless pegmatite. $A$, Layers in the wall zone. $B$, Beryl in the wall zone ............ Facing

4. Geologic map, Peerless pezmatite.

5. Geologic map of underground workings, Peerless pegmatite.

6. Geologic sections, Peerless pegmatite.

7. Correlation charts of the Peerless pegmatite.

Frgure 1. Index map showing location of Peerless pegmatite

2. Geologic maps, Peerless pegmatite

\section{TABLES}

TABLE 1. Production of mica, potash feldspar, soda feldspar, beryl, amblygonite-montebrasite, tantalite-columbite, and cassiterite, Peerless pegmatite, 1907-September 1950

2. Production of punch and sheet mica, Peerless pegmatite, 1943-47

3. Approximate mode of internal structural units, Peerless pegmatite

4. Sequence of layers in the border and wall zones, northeastern part of main open pit, Peerless pegmatite

5. Mineralogy of quartz-muscovite-plagioclase pegmatite (zone 1, border zone)

6. Mineralogy of albite-quartz-muscovite pegmatite (zone 2, wall zone)

7. Mineralogy of cleavelandite-quartz-muscovite pegmatite (zone 3, first intermediate zone)

8. Mineralogy of perthite-cleavelandite-quartz pegmatite (zone 4, second intermediate zone)

9. Mineralogy of cleavelandite-quartz pegmatite (zone 5, third intermediate zone)

10. Spectrographic analyses of mica

11. Estimated mineral content of the Peerless pegmatite

12. Composition of minerals used in computing chemical composition of the Peerless pegmatite .

13. Estimated chemical composition of the Peerless pegmatite

14. Distribution of the principal chemical constituents

15. Sequence of layers in border and wall zones

16. Measurements of beryl in seven exposures of zone 2, albite-quartz-muscovite pegmatite (wall zone) ............

17. Measurements of beryl in five exposures of zone 3, cleavelandite-quartz-muscovite pegmatite (first intermediate zone)

18. Mineralogy of beryl 
, 


\title{
PEGMATITES AND OTHER PRECAMBRIAN ROCKS IN THE SOUTHERN BLACK HILLS \\ GEOLOGY AND BERYL DEPOSITS OF THE PEERLESS PEGMATITE, PENNINGTON GOUNTY, SOUTH DAKOTA
}

\author{
By Douglas M. Sheridan, Hal G. Stephens, \\ Mortimer H. StaAtz, and James J. Norton
}

\begin{abstract}
The Peerless pegmatite, half a mile south of Keystone, Pennington County, S. Dak., has been a major source of scrap mica and beryl. Feldspar, amblygonite-montebrasite, tantalite-columbite, and cassiterite also have been recovered.

The pegmatite intrudes Precambrian quartz-mica schist. Much of the schist contains staurolite and chlorite. Staurolite has been, in part, altered to mica, quartz, and chlorite, especially near pegmatite contacts. The pegmatite is generally discordant with the schist, but in many places a secondary schistosity has been formed parallel to the contact. Tourmaline and muscovite, presumably introduced by pegmatitic solutions, are characteristic of the wall rock near discordant contacts.

At the surface the pegmatite has a tadpole shape, and is $\mathbf{5 8 0}$ feet long and 360 feet wide. In cross section the pegmatite has an anticlinal shape that indicates control of the intrusion by fractures bearing N. $30^{\circ} \mathrm{W}$. and dipping $45^{\circ}$ NE. and $\mathrm{SW}$. Dikelike apophyses extending from the main pegmatite have several attitudes.

The Peerless is a complex pegmatite consisting of 7 zones, 2 replacement units, and 2 types of fracture fillings. The zones are as follows: 1, quartz-muscovite-plagioclase pegmatite (border zone); 2, albite-quartz-muscovite pegmatite (wall zone); 3 , cleavelandite-quartz-muscovite pegmatite (first intermediate zone); 4, perthite-cleavelandite-quartz pegmatite (second intermediate zone); 5 , cleavelandite-quartz pegmatite (third intermediate zone); $6 \mathrm{a}$ and $6 \mathrm{~b}$, quartz-microcline pegmatite and quartz pegmatite (fourth intermediate zone); and 7, lithia micacleavelandite pegmatite (core). The other units are: lithia micacleavelandite-quartz replacement unit; muscovite-cleavelandite replacement unit; quartz fracture fillings; and tourmalinequartz fracture fillings.

Zones 1 and 2 consist of alternating layers of different texture and mineralogic composition that are parallel to the contact. The proportion of quartz, plagioclase, muscovite, perthite, and accessory minerals in the layers differs, although layers of similar composition may occur several times in the sequence. In some layers sugary-grained albite-quartz aggregates are important constituents.

The overall mineralogic composition of zones 1 and 2 is similar to the composition of wall zones in many other Black Hills pegmatites. Zones 3 to 7 are in the normal sequence in Black Hills pegmatites.

Accessory minerals of the pegmatite include tourmaline, beryl, apatite, amblygonite-montebrasite, lithia mica, cassiterite, tantalite-columbite, garnet, spodumene, svanbergite, loellingite?, vivianite?, triploidite?, dahllite, and varicolored phosphate minerals of the lithiophilite-triphylite group and their alteration products.
\end{abstract}

The chemical composition of the pegmatite has been determined by estimating the mineral constituents of the internal units and by calculating the tonnage of these units by use of successive geologic sections. The principal constituents are: $\mathrm{SiO}_{2}$ (77.0 percent), $\mathrm{Al}_{2} \mathrm{O}_{3}$ (13.7 percent), $\mathrm{Na}_{2} \mathrm{O}$ (5.0 percent), and $\mathrm{K}_{2} \mathrm{O}$ (1. 7 percent).

Chemical composition has also been determined for four subdivisions of the pegmatite: zones 1 and 2; zones 3 and 4; zone 5; and zones 6 and 7 and the replacement units. The content of $\mathrm{SiO}_{2}$ increases, and the content of $\mathrm{Al}_{2} \mathrm{O}_{3}$ decreases inward from the outer part of the pegmatite. $\mathrm{Na}_{2} \mathrm{O}$ forms only 0.4 percent of the inner subdivision, but 4.7 to 6.5 percent of the other subdivisions. $\mathrm{K}_{2} \mathrm{O}$ forms 4.0 percent of zones 3 and 4 , but only 0.7 to 1.3 percent of the other subdivisions.

The structural, textural, and mineralogic data confirm previously published evidence from other Black Hills pegmatites that indicates crystallization of a magmalike fluid from the wall inward. Repetition of layers in zones 1 and 2 indicates changes in composition of the fluid at the crystallizing face. These changes may have been caused by addition of new material from below, by loss of material to the wall rocks, or by failure of convection to maintain equilibrium throughout the fluid in the pegmatite chamber. Zones 3 to 7 are in the normal sequence of zoned pegmatites that indicates crystallization from a restrieted or nearly closed system. The lithia mica-cleavelandite-quartz replacement unit, which extends outward from the core, show's that in the very late stages of crystallization a pneumatolytic or hydrothermal fluid escaped outward and replaced previously crystallized pegmatite.

Zone 3 , the principal minable unit, contains 1.7 percent beryl and 28 percent scrap mica. Beryl also constitutes more than 1 percent of parts of the wall zone, especially albite-rich layers of the inner part of the unit in the upper part of the pegmatite. Beryl is a less important constituent of other units of the pegmatite.

Potash feldspar is mined chiefly from zone 4 . Cleavelandite that can be hand cobbed and sold as soda feldspar occurs in zones 3, 4, and 5. Amblygonite-montebrasite constitutes between 0.5 and 1.0 percent of zone 5 .

Reserves of beryl, scrap mica, potash feldspar, and amblygonite-montebrasite are one to six times past production.

\section{INTRODUCTION}

\section{IOCATION}

The Peerless pegmatite is in the Keystone district, Pennington County, S. Dak. This district is near the northeast edge of the large area of granitic rocks surrounding Harney Peak in the southern Black Hills. 
The Peerless pegmatite is in a group of zoned pegmatites, within an area of less than 1 square mile, which has been the source of the greater part of the pegmatite mineral production of the Keystone district. Other major pegmatite deposits in this group are the Hugo, Etta, White Cap, and Edison (fig. 1). Pegmatites also have been mined in the Hill City district, northwest of Harney Peak, and in the Custer district, southwest of the peak.

The Peerless mine is in sec. 8, T. 2 S., R. 6 E., Black Hills guide meridian, about half a mile south of Keystone (fig. 1). The pegmatite crops out between an altitude of 4,530 and 4,700 feet along the crest of a ridge that trends southeastward from the junction of

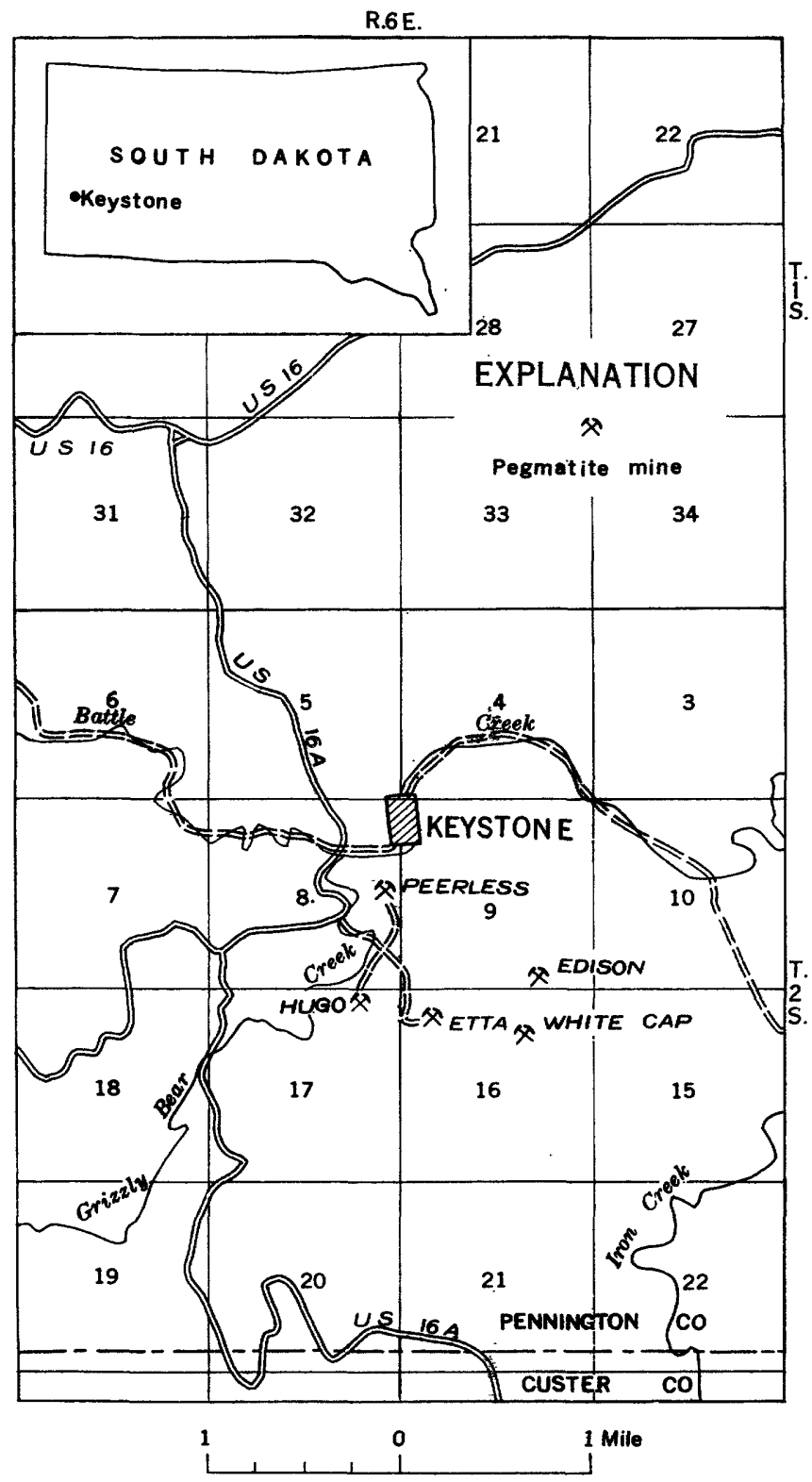

Frovra 1.--Index map showing location of Peerless pegmatite, Pennington County, 8. Dak.
Battle and Grizzly Bear Creeks. The crest of the ridge is about 350 feet above the valley floor. Relief is rugged, and the pine-covered slopes drop steeply to the valleys below.

The Peerless mine can be reached from Keystone, the nearest railhead, by 1.1 miles of paved and dirt road:

Miles

0.0 Keystone, at intersection of Chicago, Burlington, \& Quincy Railroad and Highway 16A. Travel south on Highway 16A.

.6 Turn left on graded road.

.6-.8 Cross three bridges across Grizzly Bear Creek.

.8 Turn left.

1.1 Compressor house, Peerless mine.

\section{HISTORY AND PRODUCTION}

The pegmatite was first mined about 1907 for amblygonite-montebrasite by the Harney Peak Tin Mining, Milling, and Manufacturing Co., and probably it had been prospected earlier for tin by the same company. Most of the early work for amblygonite-montebrasite, however, was done by the Reinbold Metallurgical Co. Since 1924 the Keystone Feldspar and Chemical Co. has mined the property.

The Peerless pegmatite has been a source of scrap mica, beryl, potash feldspar, soda feldspar, punch and sheet mica, amblygonite-montebrasite, tantalite-columbite, and cassiterite. Production records from 1907 to 1950 are given in tables 1 and 2 . In recent years scrap mica and beryl were the principal minerals recovered.

The total recorded production of minerals, in tons, from the Peerless pegmatite to September 11, 1950, is muscovite, 8,747 ; beryl, 511.25; potash feldspar, 9,649 ; soda feldspar, 1,772 ; and amblygonite-montebrasite, 1,013. Two thousand pounds of cassiterite and 930 pounds of tantalite-columbite (table 1) were also produced. This material would have a gross value at 1953 prices of about three-quarters of a million dollars.

Scrap mica has been the chief product of the Peerless pegmatite since 1924. In 1950 the scrap mica, sold to the U. S. Mica Co., Chicago, Ill., was used as artificial snow for Christmas decorations. Small quantities of punch and sheet mica were produced from 1943 to 1947 (table 2), but the total value was trivial in comparison with the value of the scrap mica.

The Peerless mine has been a major source of beryl. The production through 1950 was about 17 percent of all domestic production and 1 percent of the total world production. $^{1}$ The Peerless beryl production through

\footnotetext{
1 Percentages were calculated from domestic and world production data compiled by the U. 8. Bureau of Mines (1953, table IV-1).
} 
TABLE 1.-Production of mica, potash feldspar, soda feldspar, beryl, amblygonite-montebrasite, tantalite-columbite, and cassiterite, Peerless pegmatite, Keystone, Pennington County, S. Dak., 1907 to September 1950

[Data furnished by the Keystone Feldspar and Chemical Co. Published with permission. The tonnages are for sales in the years 1907 through Sept. 11, 1950, and are not necessarily the amounts actually mined in those years?

\begin{tabular}{|c|c|c|c|c|c|c|}
\hline Year & $\begin{array}{l}\text { Mica } \\
\text { (tons) }\end{array}$ & $\begin{array}{c}\text { Potash } \\
\text { feldspar } \\
\text { (tons) }\end{array}$ & $\begin{array}{c}\text { Soda } \\
\text { feldspar } \\
\text { (tons) }\end{array}$ & $\begin{array}{l}\text { Beryl } \\
\text { (tons) }\end{array}$ & $\begin{array}{l}\text { Ambly- } \\
\text { gonited- } \\
\text { monte- } \\
\text { brasite } \\
\text { (tons) }\end{array}$ & $\begin{array}{l}\text { Tantalite- } \\
\text { columbite } \\
\text { (pounds) }\end{array}$ \\
\hline $307-8$ & & & & & 900 & \\
\hline 19 & & & & 3 & & \\
\hline & $\begin{array}{r}46 \\
178\end{array}$ & $\begin{array}{l}354 \\
512\end{array}$ & & & & \\
\hline 1926 & 543 & 262 & & & & \\
\hline & $\begin{array}{l}571 \\
{ }_{314}\end{array}$ & 121 & & $\cdots$ & 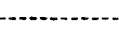 & 200 \\
\hline & 257 & 267 & & $157^{\circ}$ & & 320 \\
\hline $1930_{-}$ & 257 & 61 & & 39 & & \\
\hline & & 708 & & & & \\
\hline & 8 & 160 & 42 & 8 & & \\
\hline & 159 & 290 & 18 & 20 & 12 & - \\
\hline & 281 & 328 & 58 & & & \\
\hline 1936 & 429 & 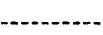 & 49 & & & \\
\hline & $\begin{array}{l}401 \\
417\end{array}$ & $\cdots$ & $\begin{array}{r}60 \\
151\end{array}$ & 36 & & 140 \\
\hline & $\begin{array}{l}297 \\
534\end{array}$ & $\ldots$ & $\begin{array}{r}174 \\
73\end{array}$ & $\begin{array}{l}28 \\
31\end{array}$ & $\cdots$ & \\
\hline 1941 & 725 & & & 25 & & \\
\hline & $\begin{array}{l}390 \\
218\end{array}$ & 2,221 & 385 & $\begin{array}{l}43 \\
45\end{array}$ & $\cdots$ & 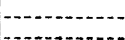 \\
\hline & 175 & $\begin{array}{l}1,269 \\
1,947\end{array}$ & 99 & 9 & 7 & $\ldots$ \\
\hline & 33 & 490 & & 6 & & \\
\hline & 3331 & 45 & 113 & 8 & & 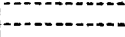 \\
\hline & $\begin{array}{r}289 \\
344\end{array}$ & (4) & 233 & 10 & - & $\ldots$ \\
\hline 190 & 200 & (4) & 79 & $94 / 4$ & - n & - \\
\hline Total 4 & 8,747 & 9,649 & 1,772 & $5111 / 4$ & 1,013 & 93 \\
\hline
\end{tabular}

1 The amblygonite-montebrasite production from the Keystone district during 1911-16 totaled 1,502 tons, part of which probably came from the Peerless pegmatite. 2 The amblygonite-montebrasite production from the Peerless pegmatite and the Hugo pegmatite totaled 387 tons between 1917 and 1919 inclusive.

${ }^{3}$ The 423 tons of mica sold in 1932 and 8 tons of the 1947 production were designated "mica schist", which is the miner's term for scrap mica that oceurs in fne-grained $<0.5$ inch) aggregates.

A Feldspar production in the years 1948, 1949, and 1950 was recorded as "spar." A. F. Walker stated that the sales were predominantly soda feldspar in these years." Chemical Co. since 1924, but no sales of this mineral have been recorded.

1949 was 26 percent of the total beryl production cited by Smith (1950, p. 6) for South Dakota.

Potash and soda feldspar have also been major products of this mine. The demand for soda feldspar, however, is so small that it is ordinarily stockpiled so that it can be sold whenever orders are received.

The total amblygonite-montebrasite production may be several hundred tons more than the 1,013 tons recorded in table 1. Most of the amblygonite-montebrasite was mined before 1924 by the Reinbold Metallurgical Co., which mined rich areas in the upper part of the main pit and in the old cut northwest of it (pl. 4). The Keystone Feldspar and Chemical Co. sold 106 tons between 1924 and 1935, but only 7 tons was produced from 1935 to September 1950 (table 1).

Tantalite-columbite, the only other mineral that has been sold, has been a minor byproduct. About 2,000 pounds of cassiterite has been accumulated since 1924 , but no sales have been recorded.
TABLE 2.-Production of punch and sheet mica, in pounds, Peerless pegmatite, Keystone, Pennington County, S. Dak., 1943-47

[Data furnished by the Keystone Feldspar and Chemical Co. Published with permission]

\begin{tabular}{|c|c|c|}
\hline Year & Punch mica & Sheet mica \\
\hline $\begin{array}{l}1943 \\
1944 \\
19456 \\
1947\end{array}$ & $\begin{array}{r}312.50 \\
122.31 \\
255.00 \\
279.00\end{array}$ & $\begin{array}{r}279.99 \\
127.58 \\
29.88 \\
\end{array}$ \\
\hline Total & 868.81 & 437. 45 \\
\hline
\end{tabular}

1 Not stated whether punch or sheet mica.

PAST AND PRESENT INVESTIGATIONS

The Peerless pegmatite was mentioned in several early geologic publications, but the first extensive report was by Hess (1925). He discussed mineralogic relationships and textures in the Peerless pegmatite and briefly described the shape of the outcrop. Landes (1928) deseribed the Peerless pegmatite and discussed the sequence of the minerals. Schwartz (1928, p. 61-62) described this pegmatite briefly. F. H. Klaer, $\mathrm{Jr}^{2}{ }^{2}$ described the Peerless and other pegmatites in the Keystone area. W. C. Stoll (Page and others, 1953, p. 175-176) and W. E. Hall examined and mapped the Peerless pegmatite in 1942 during reconnaissance investigations for strategic minerals by the U. S. Geological Survey.

More detailed investigations of the Peerless pegmatite were started by the Geological Survey in July 1947. The first work was done by W. R. Thurston and A. J. Lang, Jr. Between August and December 1947, M. H. Staatz and H. G. Stephens, assisted at different times by J. W. Adams and L. R. Page, completed the surface mapping and part of the underground mapping, and prepared preliminary geologic sections (Stephens and Staatz, 1948, p. 1,400).

In January 1949, Stephens prepared proposals for diamond drilling and experimental mining at the Peerless pegmatite at the request of the U. S. Bureau of Mines. On August 30,1949, a core-drilling program began, and the work was completed on December 15 . Seven holes totaling 1,573.5 feet were drilled under the supervision of Stuart Ferguson and Eugene O. Binyon of the Bureau of Mines. Geologic work during the drilling, including revision and extension of existing maps and sections, was done by D. M. Sheridan, R. E. Roadifer, and J. J. Norton of the Geological Survey. D. M. Sheridan logged the core.

The Bureau of Mines conducted an experimental mining project at the Peerless pegmatite during 1950-51. This work consisted of driving an adit along

2 Klaer, F. H., Jr., 1937, The Peerless and related pegmatites, Keystone, S. Dak. Unpublished thesis, Northwestern Univ., Evanston, Ill. 
diamond-drill hole 5 (pls. 4-6) to test the results obtained from the drill hole. . The coarse material from the adit was hand sorted on a picking belt to gather data on mineral content, and the fine material was treated metallurgically (Runke, Mullen, and Cunningham, 1952, p. 21-22, 23, 30-31). The adit was mapped by Staatz and Sheridan in January and April 1951. L. R. Page and J. A. Redden examined the sequence of layers in the border and wall zones in April 1954; their results were used in compiling table 4. An abstract of this report has been published previously (Sheridan and others, 1955, p. 1,616).

\section{ACKNOWLEDGMENTS}

The writers wish to thank Ernest Reckitt, president, J. A. Schreiber, general manager, and A. F. Walker, resident superintendent, of the Keystone Feldspar Chemical Co. for their kind cooperation in providing production data. Appreciation is also extended to members of the Bureau of Mines for their assistance and cooperation in obtaining geologic information during their diamond-drilling and experimental mining programs.

This investigation was done partly on behalf of the U. S. Atomic Energy Commission.

\section{MINE WORKINGS}

The Peerless pegmatite has been worked by opencut and underground mining methods. Most of the recent mining has been conducted in the underground workings (pl. 5), in the main pit (pl. 4), and in two new opencuts started after the surface map was made. The main pit (pl. 4) is in the southeastern part of the pegmatite. It is about 220 feet long, 105 feet wide, and has a maximum depth of 115 feet. A 100-foot access cut extends southward from the main pit, and another cut extends westward 160 feet from the southwest edge of the main pit to a point above the portal of the adit. A small cut northwest of the adit portal is 60 feet long and 50 feet in maximum depth. Older workings in the northern and western parts of the pegmatite consist of 5 small opencuts (pl. 4) 10 to 110 feet long and 4 to 55 feet wide. Two new opencuts were started on the northeastern part of the pegmatite by the Keystone Feldspar and Chemical Co. in 1950, at the same time that the Bureau of Mines was driving an adit for experimental mining tests along drill-hole 5 from the southwest side of the pegmatite.

Underground workings having a length of 735 feet are in the southern and eastern parts of the pegmatite (pl. 5) at an altitude of 4,540 feet. Stopes to a maximum height of 20 feet have been made in the pegmatite along the first intermediate zone. After the geologic map (pl. 4) was made, the underground workings were extended into the main pit through two glory holes having dimensions of 40 by 20 feet and 25 by 30 feet at the adit level.

The Bureau of Mines experimental adit (pl. 5), by July 1, 1951, had been extended 165 feet northeastward along diamond-drill hole 5 . The altitude of the new adit is about 4,580 feet.

Four large dumps southwest of the Peerless pegmatite are all more than 80 feet wide and 120 feet long. The material in the three largest ones came from the main pit; each dump represents a different stage in the mining. In addition, there are at least seven smaller dumps on the pegmatite deposit and along its northeast side; most of the material came from the smaller pits. Calculations made in 1947 indicated a total of 113,000 tons of rock in the Peerless dumps. Since that time there has been a slight increase in the size of the large dump southwest of the pegmatite (pl. 4), and a new one has been added on the northeast side.

\section{GEOLOGY}

\section{METAMORPHIC ROCKS}

The Precambrian country rock consists predominantly of gray to brownish-gray schist consisting of quartz, mica, chlorite, staurolite, and garnet. The predominant facies is quartz-mica schist, but many beds contain essential staurolite or chlorite, and others are so deficient in mica that they are best termed micaceous quartzites. These beds are not distinguished on plates 4 and 5 because they are generally too thin to be mapped on a scale of 1:480. They range in thickness from less than 2 inches to as much as 10 feet.

The most abundant type of country rock is quartzmica schist. It has an average grain size of about 0.02 inch and contains quartz ( 45 to 65 percent), muscovite (15 to 30 percent), biotite (10 to 25 percent), chlorite ( 0 to 3 percent), and garnet $(<1$ percent). Feldspar also occurs in the schist, but the quantity was not estimated. Preferred orientation of the micaceous minerals gives the rock a strong schistosity.

Some beds of quartz-mica schist contain as much as 4 percent muscovite and biotite pseudomorphs after staurolite. Beds of micaceous quartzite contain quartz (75 to 85 percent) and muscovite and biotite (15 to 25 percent); chlorite and garnet are absent.

The beds of quartz-mica-staurolite schist are similar to the quartz-mica schist, except for the presence of metacrysts of staurolite ( 2 to 10 percent) and andalusite ( $<1$ percent). Staurolite occurs commonly as cruciform twins. The length ranges from 0.1 to 2 inches and averages about 0.4 inch. Indices of refraction are: $\mathrm{N} \gamma=1.75 ; \mathrm{N}_{\alpha}=1.74$. Less abundant, pink prismatic metacrysts of andalusite average about 1 inch in length. 

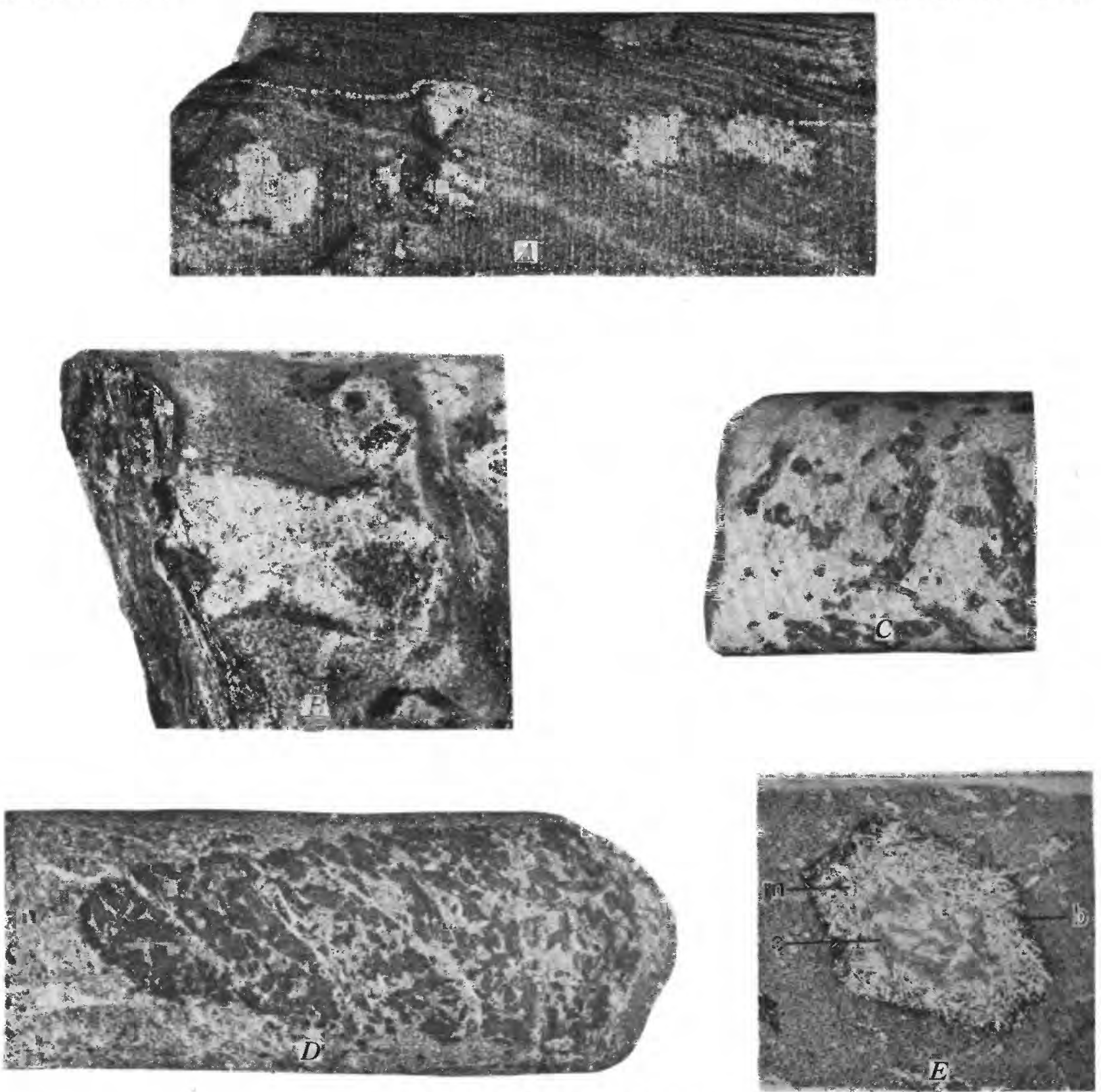

WALL ROCK, PEERLESS PEgMatite.

$A$, Quartz-mica schist containing staurolite partly changed to muscovite, chlorite (ripidolite), quartz, and biotite, $\times 1$ 1/2 $B$, Schist in which staurolite has heen completely replaced by muscovite, quartz, and biotite, $\times 1144$. $C$ and $D$, Tourmalinized schist (natural size). E, Pseudomorph of a staurolite erystal, $\times 213$. Quartz-mica-chlorite schist at depth of 34.8 feet in drill hole 5 , and 35.5 feet from the pegmatite contact. The groundmass contains quartz (50 percent), hiotite (25 percent), muscovite (20 percent), chlorite ( 5 percent), and titanite (trace). Pseudomorphs of euhedral staurolite crystals forming 5 to 10 percent of the schist are composed of muscovite ( 50 percent), quartz $(20$ percent), chlorite ( 20 percent), and biotite (10 percent). In the pseudomorph shown in the thin section, biotite $(b)$ forms the outer rim, muscovite $(m)$ forms the next layer, and chlorite $(c)$ is concentrated near the center of the pseudomorph. 


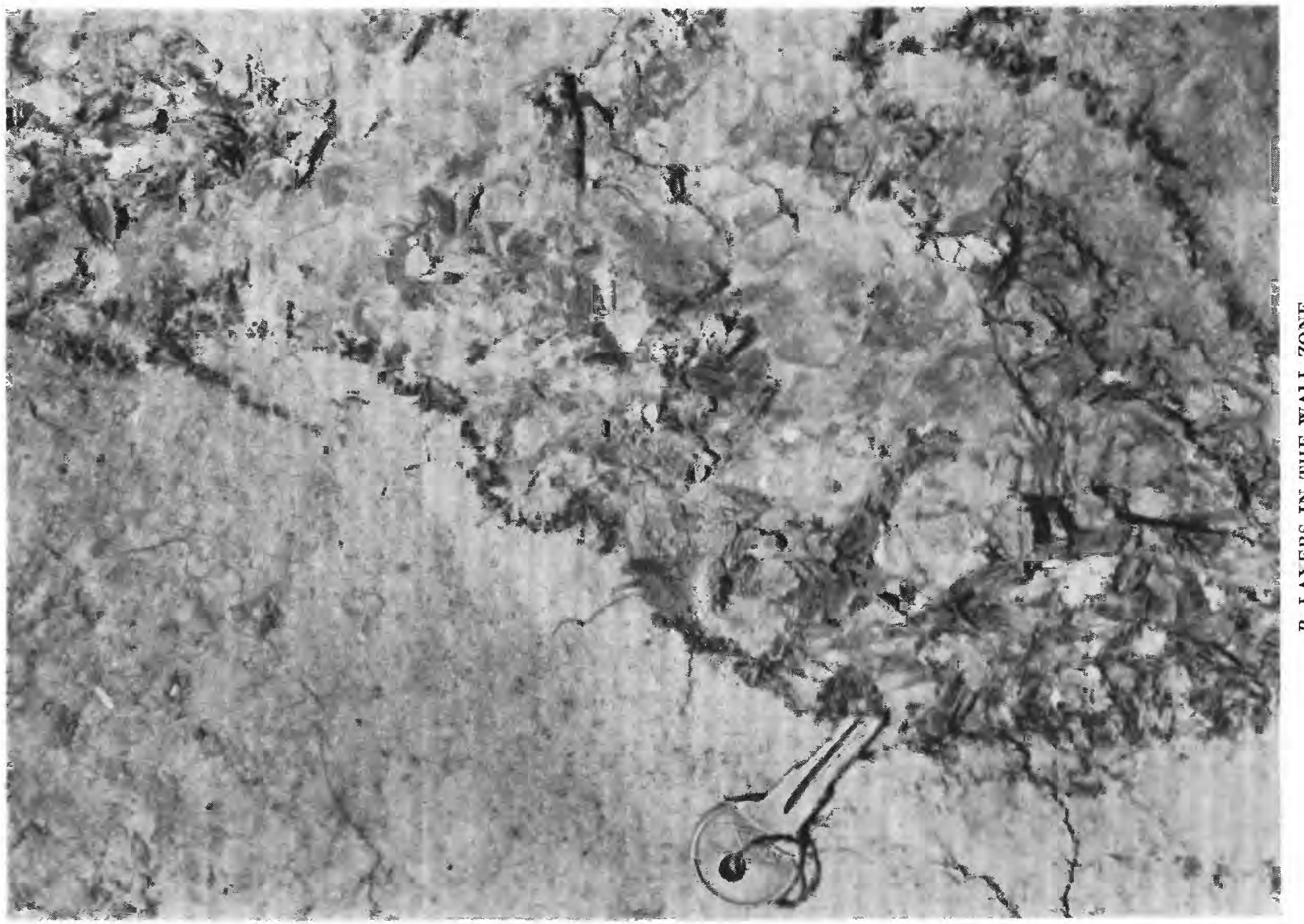

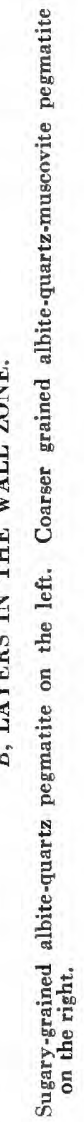
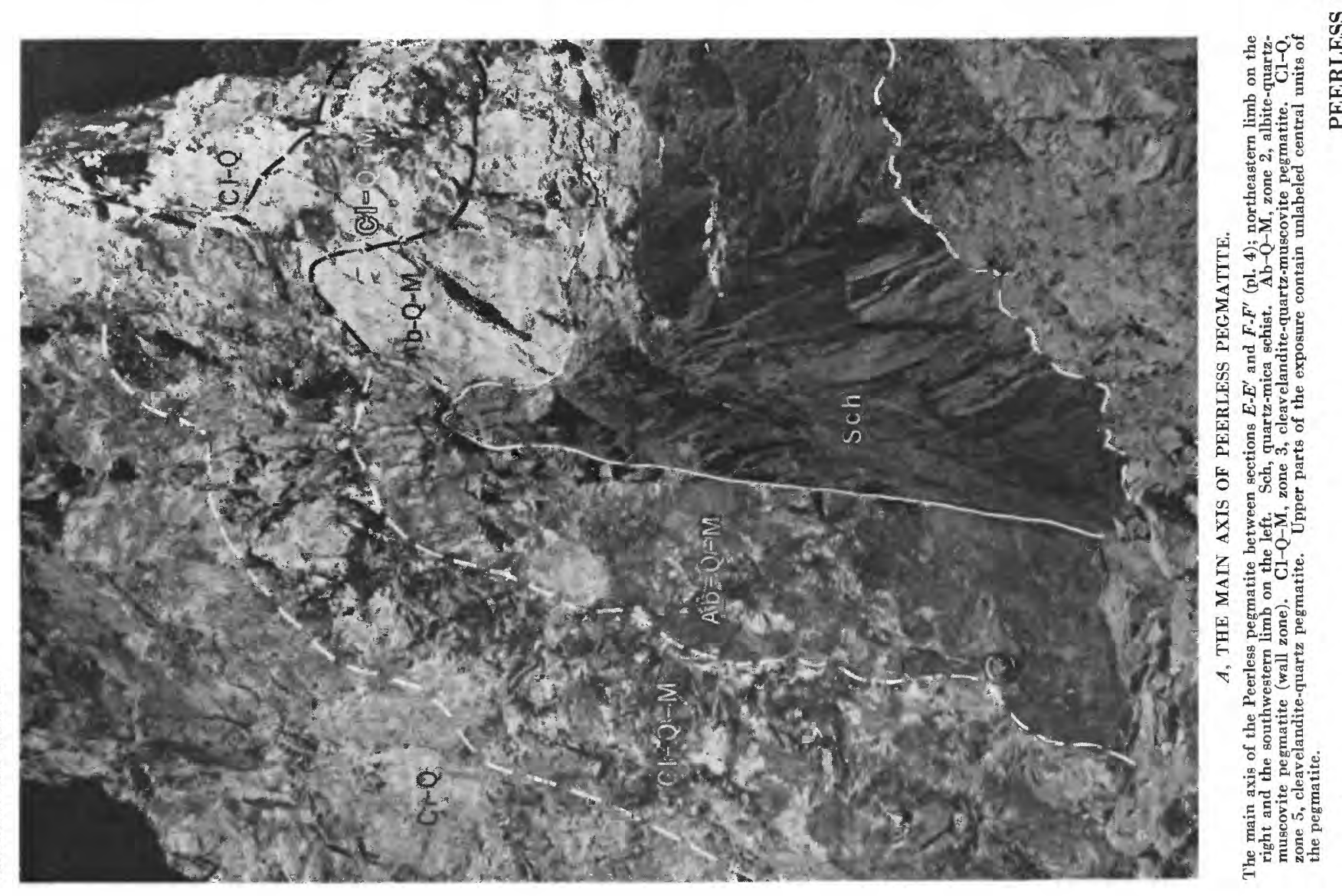
Optical data for the andalusite are: $\mathrm{N} \gamma=1.64 ; \mathrm{N}_{\alpha}=1.62$; $2 \mathrm{~V}$ near $90^{\circ}$. Red to reddish-brown crystals of garnet (average size, 0.05 inch) form 1 to 2 percent of the quartz-mica-staurolite schist. The matrix of this type of schist averages about 0.02 inch in grain size.

Some of the quartz-mica-chlorite schist is similar to the quartz-mica schist, but contains more chlorite ( 5 to 10 percent) in the form of tabular metacrysts, 0.1 to 0.3 inch in diameter. Other beds of quartzmica-chlorite schist are almost identical with quartzmica-staurolite schist except that the staurolite and andalusite are present only as relicts, and chlorite forms 3 to 10 percent of the rock (pl. 1). Pseudomorphs of muscovite, biotite, and chlorite after euhedral staurolite constitute about 5 percent of this schist. The mica flakes in the pseudomorphs average 0.05 inch in diameter, compared to the average grain size of 0.02 inch in the schist matrix. Some of the pseudomorphs contain relicts of brown staurolite; others have chlorite centers and muscovite or biotite rims (pl. 1E); still others are wholly muscovite. These pseudomorphs are more abundant near pegmatite contacts.

Garnet is more abundant along the contacts of quartz-mica-chlorite schist with more quartzose beds.

The country rock adjacent to the pegmatite contact commonly is altered to a quartz-muscovite-tourmsline schist, especially where the pegmatite cuts across the bedding and schistosity (pl. 1). The thickness of the altered rock generally is less than 4 feet, but may be as much as 9 feet. This rock contains quartz (30 to 55 percent), muscovite (30 to 45 percent), tourmaline ( 5 to 40 percent), and apatite ( $<1$ percent). The tourmaline $\left(\mathrm{N}_{\omega}=1.67\right)$ is in black euhedral needles that range in length from 0.1 to 1.1 inches. Bluish-green grains of apatite $\left(\mathrm{N}_{\omega}=1.63\right) 0.05$ inch or less in diameter are common only within a few inches of the pegmatite contact. The average grain size of the altered schist is about 0.04 inch which is somewhat coarser than that of the unaltered rock. In some places the only visible alteration of the schist has been the destruction of biotite and only a negligible addition of tourmaline; in other places there has been no apparent alteration.

The average strike of bedding is almost directly eastward, and the average dip is $85^{\circ} \mathrm{S}$. The structure of the schist is not known completely, although the schist has been studied not only in the area shown on plate 4, but also in adjacent areas. Probably the tops of beds are generally to the north, but there may be some reversals caused by folding. Minor folds have not been studied in detail.

The schistosity near the edges of the mapped area (pl. 4) is nearly parallel to the bedding, but the average dip may be at a lower angle to the south than the bedding dip. Nearer the pegmatite the attitude of the schistosity becomes parallel or nearly parallel to the contact. This relationship is shown especially well on the 4,540-foot level (pl. 5) and east of the open pit (pl. 4). Nonetheless, schistosity at the contact may be discordant by as much as $20^{\circ}$.

All types of schist are cut by many quartz stringers that range in thickness from 0.05 to more than 12 inches. Some of the stringers are parallel to the foliation, but many crosscut the foliation at different angles. Most of the stringers consist entirely of colorless to slightly milky, massive quartz; a few contain as much as 20 percent plagioclase. The minimum index of refraction $\left(\mathrm{N}_{\alpha}{ }^{\prime}\right)$ of (001) cleavage fragments of the plagioclase in one of these stringers is 1.543 , indicating that the plagioclase is oligoclase, $\mathrm{An}_{29}{ }^{3}$ Some of the quartz veins and the adjacent schist contain small specks of chalcopyrite, pyrite, and pyrrhotite.

\section{QUARTZ-PLAGIOCLASE-MUSCOVITE PEGMATITE, UNDIFFER ENTIATFD}

Undifferentiated quartz-plagioclase-muscovite pegmatite cuts the schist in the southwestern part of the mapped area (pl. 4). The texture differs from place to place but is generally fine grained. The maximum grain size is about 1 inch. Part of the albite and quartz occurs as sugary-grained aggregates.

\section{PEERLESS PEGMATITE}

The Peerless pegmatite is a large complex pegmatite that has an anticlinal shape in cross section, and has a tadpole shape on the surface (pls. 4, 6, and fig. 2). The pegmatite contains 7 zones, 2 replacement units, and 2 types of fracture fillings. These units consist chiefly of differing proportions of quartz, plagioclase, perthite, muscovite, and lithia mica. Chemically this pegmatite has a relatively simple composition; it consists almost entirely of four oxides: $\mathrm{SiO}_{2}, \mathrm{Al}_{2} \mathrm{O}_{3}, \mathrm{Na}_{2} \mathrm{O}$, and $\mathrm{K}_{2} \mathrm{O}$. Evidence indicates that this pegmatite crystallized from a magmalike fluid consisting chiefly of these oxides and an unknown quantity of water.

\section{SIZE, SHAPE, AND STRUCTURE}

The long axis of the pegmatite outcrop trends northwestward for about 580 feet; the maximum width of the exposure is about 360 feet. The attitudes of the anticlinelike limbs and discordance with the schist indicate control of the intrusion by fractures striking about N. $30^{\circ} \mathrm{W}$. and dipping about $45^{\circ} \mathrm{E}$. and W. (pl. 4 and fig. 2). The axis has a low angle of plunge (fig. 2 and pl. 2), which is $10^{\circ} \mathrm{S} .27^{\circ} \mathrm{E}$. on the underside of the southern part of the pegmatite; to the north it changes to $2^{\circ} \mathrm{N} .34^{\circ} \mathrm{W}$, and still farther north is $5^{\circ}$ N. $49^{\circ} \mathrm{W}$.

\footnotetext{
The anorthite content of plagioclase is determined from Grout (1932, p. 468, flg. 264).
} 

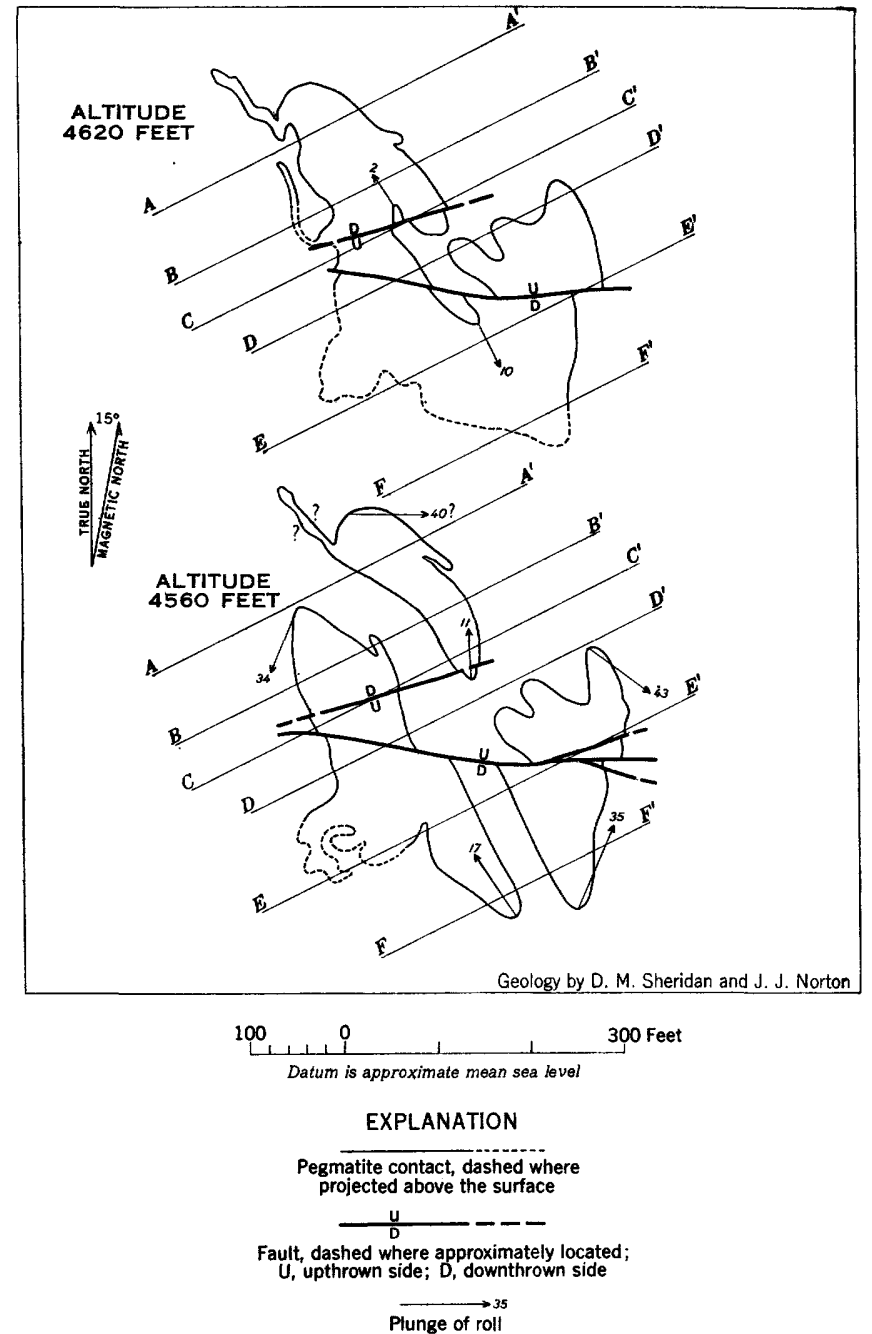

FIGURe 2.-Geologic maps, Peerless pegmatite, at altitudes of 4,560 and 4,620 feet.

Geologic maps at the 4,560- and 4,620-foot levels (fig. 2) show the changes in shape of the pegmatite above and below the axis. At the 4,560-foot level the pegmatite is divided into three segments; two on the northeastern limb and one on the southwestern limb. At the 4,620-foot level the southwestern limb is joined to both segments of the northeastern. The two segments of the northeastern limb may also join each other at this level, even though they are separated above (pl. 4) and below (fig. 2).

The keels of the southwestern limb and each segment of the northeastern limb plunge northward at the south end and southward at the north end (fig. 2). The geologic sections (pl. 6) indicate that the keel of the southwestern limb plunges $34^{\circ} \mathrm{S} .23^{\circ} \mathrm{W}$. from sections $A-A^{\prime}$ to $B-B^{\prime}$ and is probably horizontal from sections $B-B^{\prime}$ to $D-D^{\prime}$. Farther south the underside of the pegmatite has three large rolls, rather than one simply defined keel. These rolls plunge $5^{\circ}$ to $25^{\circ} \mathrm{N} .5^{\circ} \mathrm{E}$. to $\mathrm{N} .35^{\circ} \mathrm{W}$.
The two segments of the northeastern limb are structurally similar to the southwestern limb. The south segment is structurally simple at its south end, but it has at least three major rolls at the north end. The keel is probably horizontal just south of section $E-E^{\prime}$.

The keel of the north segment of this limb plunges northward from section $C-C^{\prime}$ to $A-A^{\prime}$. Farther north it probably curves upward to join the crest. This conclusion is indicated by dips of $65^{\circ}$ to $80^{\circ}$ and easterly plunges at the north end of the outcrop (pl. 4).

In addition to these three large structures and their minor rolls, there are several dikelike apophyses that extend outward from the main body of the pegmatite. The two chief ones are on the west side of the pegmatite near the north end (pls. 4, 6, and fig. 2). These are irregular and discordant with the schist; the principal attitude is a strike of N. $20^{\circ} \mathrm{W}$. and a dip of $70 \circ \mathrm{E}$. A footwall roll in drill hole 6 (pl. 6) may have a similar structure.

\section{INTERNAL UNITS}

The Peerless pegmatite has a sequence of 7 zones, 2 replacement units, and 2 types of fracture-filling units. The outermost unit is a border zone, one-half inch thick, consisting predominantly of quartz, but also containing muscovite and blocky albite-oligoclase. Blocky to subplaty albite becomes predominant in the wall zone as quartz and muscovite diminish (table 3). Both the border and wall zones consist of a series of layers that differ greatly in texture and in content of quartz, feldspar, and muscovite. In zone 3 , which contains more muscovite than any other, albite is the chief mineral, but it is predominantly cleavelandite. Very coarse grained microcline-perthite is the principal mineral of the hood-shaped zone 4 at the top of the pegmatite; muscovite is minor, and the cleavelandite-quartz groundmass is much the same as in zone 3 . The groundmass of zones 4 and 5 is similar. Sharp changes take place at the contact with zone 6 , which consists chiefly of quartz, but a subsidiary unit containing nonperthitic microcline forms a hood at the top of this zone. The core consists principally of lithia mica, but it also contains cleavelandite. The core is bordered by a replacement unit in which the introduced minerals are the same as the minerals of the core, but relicts of zones 3 through 6 can also be recognized. Minor units of the pegmatite include fracture fillings containing quartz and tourmaline, and also a mass of muscovitecleavelandite pegmatite that probably is a replacement unit.

The minerals of the Peerless pegmatite include albite, quartz, muscovite, microcline-perthite, nonperthitic microcline, tourmaline, beryl, apatite, amblygonitemontebrasite, lithia mica, cassiterite, tantalitecolumbite, garnet, loellingite(?), chalcopyrite, limonite, 
spodumene, svanbergite, vivianite(?), dahllite, triploidite(?), an unidentified bluish-green to dark-green mineral, and varicolored phosphate minerals (probably chiefly members of the lithiophilite-triphylite group) and their alteration products. Other minerals that have been reported in the literature, but not observed during the present investigations, include struverite (strueverite, Ziegler, 1914a, p. 115), stannite and alteration products of stannite (Headden, 1893, p. 105-110), autunite and torbernite (Ziegler, 1914a, p. 206-207), and possibly rare chrysoberyl (Page and others, 1953, p. 11).

Table 3 gives detailed data concerning the mineralogic composition of the pegmatite units. The percentages of the minerals listed in table 3 have been compiled from visual estimates at many exposures, both at the surface and in underground workings, and from visual estimates of the drill cores. Beryl figures are based partly on grain measurements.

Pegmatitic textural terms in this report are adapted from the classification by Cameron, Jahns, McNair, and Page $(1949$, p. 16). The terms "very fine grained" and "sugary-grained" have been added. The terms and grain sizes used in this report are as follows:

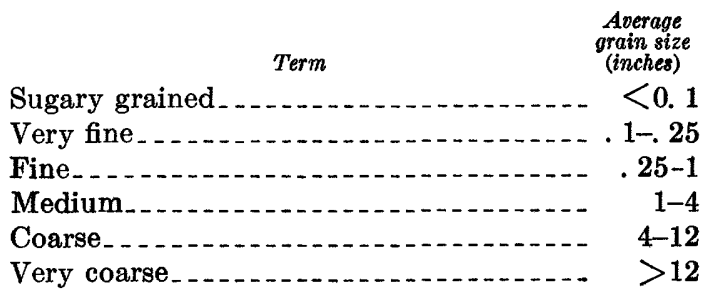

Quartz-muscovite-plagioclase pegmatite (zone 1, border zone) and albite-quartz-muscovite pegmatite (zone 2 , wall zone). - The overall composition of the border zone is quartz-muscovite-plagioclase pegmatite, and the wall zone is albite-quartz-muscovite pegmatite. These zones can be further subdivided into a series of pegmatite lenses or layers (pl. 2). The structural layers have been defined from studies of this and other Black Hills

TABLE 3.-Approximate mode of internal structural units, Peerless pegmatite ${ }^{1}$

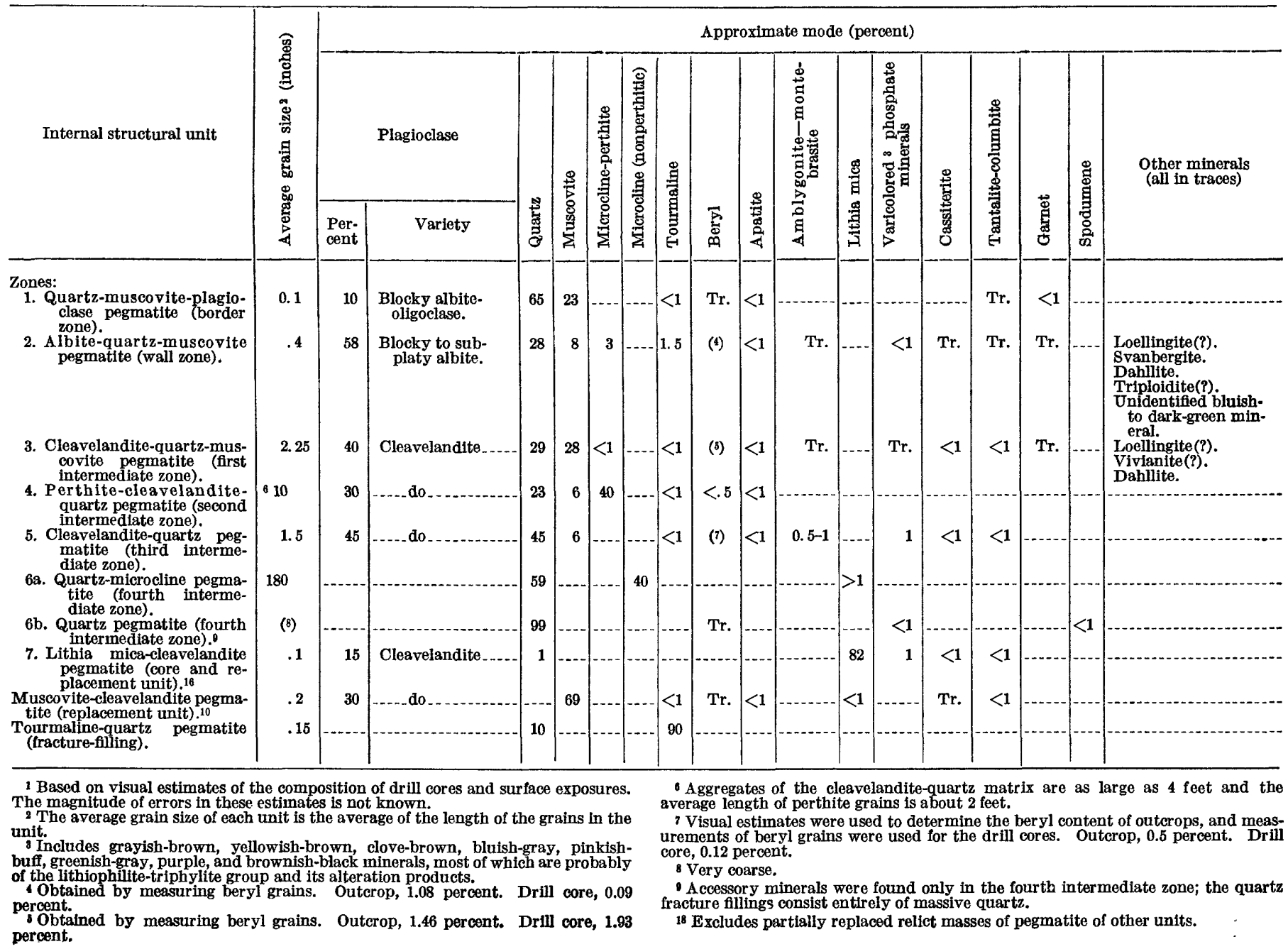


TABLE 4.-Sequence of layers in the border and wall zones, northeastern part of the main open pit, Peerless pegmatite

[Geology by L. R. Page and J. A. Redden]

\begin{tabular}{|c|c|c|c|c|c|c|}
\hline \multirow{2}{*}{$\begin{array}{c}\text { Order } \\
\text { of } \\
\text { layers } \\
\text { inward } \\
\text { from } \\
\text { pegma- } \\
\text { tite } \\
\text { contact }\end{array}$} & \multirow{2}{*}{$\begin{array}{l}\text { Correlative layer } \\
\text { in drill holes } \\
\text { (pl. } 7)\end{array}$} & \multirow{2}{*}{$\begin{array}{c}\text { Thick- } \\
\text { ness } \\
\text { (ft) }\end{array}$} & \multicolumn{2}{|c|}{ Approximate mode } & \multirow{2}{*}{$\begin{array}{l}\text { Aver- } \\
\text { age } \\
\text { grain } \\
\text { size } \\
\text { (in.) }\end{array}$} & \multirow{2}{*}{$\begin{array}{l}\text { Younger than } \\
\text { layer- }\end{array}$} \\
\hline & & & Mineral & $\begin{array}{l}\text { Per- } \\
\text { cent }\end{array}$ & & \\
\hline 11 & Q-Ab & 3 & $\begin{array}{l}\text { Quartz } \\
\text { Albite............. }\end{array}$ & $\begin{array}{l}65 \\
35\end{array}$ & $11 / 2$ & 10 \\
\hline 10 & $\begin{array}{l}\text { Varlant of upper } \\
\mathrm{Ab}-\mathbf{Q}-\mathbf{M} \text {. }\end{array}$ & 4 & $\begin{array}{l}\text { Quartz } \\
\text { Albite......... } \\
\text { Muscovite..... }\end{array}$ & $\begin{array}{l}45 \\
40 \\
15\end{array}$ & $11 / 2$ & 8 \\
\hline$\theta$ & $\begin{array}{l}\text { Variant of } A b- \\
\mathbf{Q - P .}\end{array}$ & $0-.5$ & $\begin{array}{l}\text { Perthite } \\
\text { Quartz } \\
\text { Albite } \\
\text { Muscovite... } \\
\text { Tourmaline } \\
\end{array}$ & $\begin{array}{l}40 \\
30 \\
10 \\
10 \\
10\end{array}$ & 3 & $\begin{array}{l}8 \text { and 10. Segre- } \\
\text { gation or frac- } \\
\text { ture flling. }\end{array}$ \\
\hline 8 & $\begin{array}{l}\text { Middle Ab- } \\
\text { Q-M. }\end{array}$ & $5-6$ & 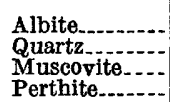 & $\begin{array}{r}65 \\
25 \\
5 \\
\text { Tr. }\end{array}$ & $8 / 8$ & 7 \\
\hline 7 & None & 3 & $\begin{array}{l}\text { Quartz } \\
\text { Muscovite... } \\
\text { Albite } \\
\text { (cleavelan- } \\
\text { dite). }\end{array}$ & $\begin{array}{l}60 \\
25 \\
15\end{array}$ & 2 & 6 \\
\hline 6 & $A b-Q$ & 2 & Albite.......... & 80 & (1) & 5 \\
\hline 5 & Lower $\mathbf{A b}-\mathrm{Q}-\mathbf{M}$ & 1 & $\begin{array}{l}\text { Quartz } \\
\text { Albite } \\
\text { Quartz-. } \\
\text { Muscovite... }\end{array}$ & $\begin{array}{r}20 \\
55 \\
30 \\
10-15\end{array}$ & 1 & 2 \\
\hline 4 & None & 1 & $\begin{array}{l}\text { Quartz } \\
\text { Albite } \\
\text { Muscovite......... }\end{array}$ & $\begin{array}{l}45 \\
35 \\
20\end{array}$ & 2 & $\begin{array}{l}3 \text { and } 5 . \text { Segre- } \\
\text { gation or frac- }\end{array}$ \\
\hline 3 & Lower Ab-Q-M & 1 & $\begin{array}{l}\text { Albite_. } \\
\text { Quartz } \\
\text { Muscovite... }\end{array}$ & $\begin{array}{r}55 \\
30 \\
10-15\end{array}$ & 1 & $2^{\text {ture filling. }}$ \\
\hline 2 & $\mathbf{Q}-\mathbf{A b}-\mathbf{M}$ & .25 & $\begin{array}{l}\text { Quartz } \\
\text { Plagioclase_..... } \\
\text { Muscovite_... }\end{array}$ & $\begin{array}{l}45 \\
35 \\
20\end{array}$ & 1 & (2) \\
\hline 1 & Q-.. & .04 & Quartz_....... & 100 & (?) & (4) \\
\hline
\end{tabular}

1 Sugary grained.

3 Probably the oidest unit in the sequence.

Massive.

1 Probably younger than layer 2 .

pegmatites, as differing in mineralogic composition or texture, or both; they are parallel to the pegmatite contact, and may be continuous around the entire body.
The layers may be cut by fracture fillings or replacement units, and they may be zoned.

Plate 7 shows the sequence of layers and probable correlations where the pegmatite was cut by diamonddrill holes. The horizontal line connecting the lower parts of the columns represents the pegmatite contact. The top of each column is the innermost part of the wall zone cut by the drill hole. Spaces between columns represent the approximate distance between drill bole intersections as measured along dip in sections $A-A^{\prime}$, $B-B^{\prime}, C-C^{\prime}$, and $D-D^{\prime}$, or along strike in the three charts for the hanging wall and footwall. Table 4 shows a somewhat similar sequence in the main open pit.

The border zone is very fine grained; the average grain size is 0.1 inch. The thickness is generally about 0.5 inch, but the maximum is 2.5 inches. The largest exposures of border zone occur as dip slopes along the northern and northeastern flanks of the pegmatite (pl. 4); elsewhere the zone is exposed along more steeply dipping contacts where it is too thin to constitute a mappable unit.

The average mineralogic composition of the border zone and detailed mineralogic data are given in table 5. Locally the border zone ranges from quartz pegmatite with accessory muscovite to pegmatite composed of albite (50 percent), quartz ( 35 percent), and muscovite (15 percent); several outcrops have as much as 35 percent muscovite.

Quartz is the dominant mineral in nearly all exposures of the border zone. At many places the outermost layer of the pegmatite is a thin sheet of massive quartz that may be a fracture-filling unit.

Plagioclase is sparse at the outer contact, but it increases in abundance inward. The anorthite content of the plagioclase is as much as 13 percent at the outer contact and decreases to 4 percent at the inner contact.

The wall zone is as much as 20 feet thick, but aver-

TABLE 5.-Mineralogy of quartz-muscovite-plagioclase pegmatite (zone 1, border zone), Peerless pegmatite

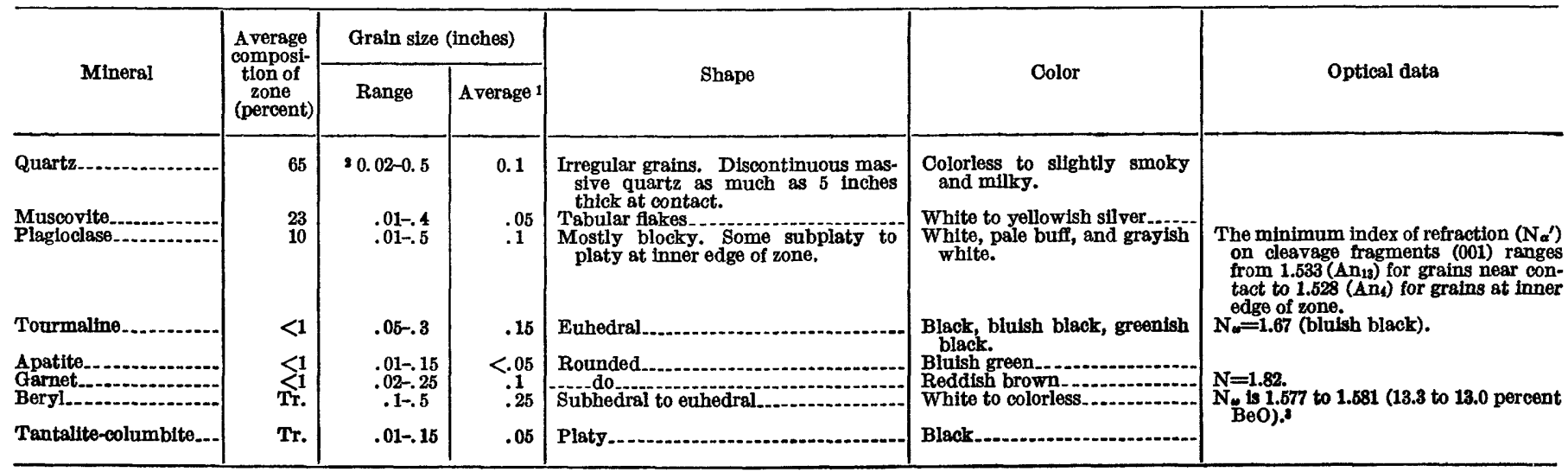

1 Average length of the grains.

BeO content of beryl by W. T. Schaller (written communication). 
ages about 5 feet. It is thickest on the footwall sides of the pegmatite limbs, and is thinnest near the crest of the body and near some of the structural rolls (pl. 6). Locally the wall zone is absent and either the first or second intermediate zone is in direct contact with the border zone.

The wall zone shows a great diversity in mineralogic composition and texture, as shown by the data on sequence of layers in table 4 and plate 7 . Most of the wall zone has a fine-grained pegmatitic texture; the average size of individual grains is about 0.4 inch but the size varies greatly. The average mineralogic composition of the wall zone is given in table 6 .

The keelward parts of the wall zone generally contain less albite and more quartz than the exposures in the upper parts of the pegmatite. In 24 segments cut by drill holes, the wall zone contains 50 percent albite, and 35 percent quartz. In contrast, an exposure of wall zone near the crest of the northern part of the pegmatite contains 70 percent albite, and 20 percent quartz. The measured beryl content is 1.08 percent in surface exposures, and only 0.09 percent in drill

TABL. 6.-Mineralogy of albite-quartz-muscovite pegmatite (zone 2 , wall zone), Peerless pegmatite

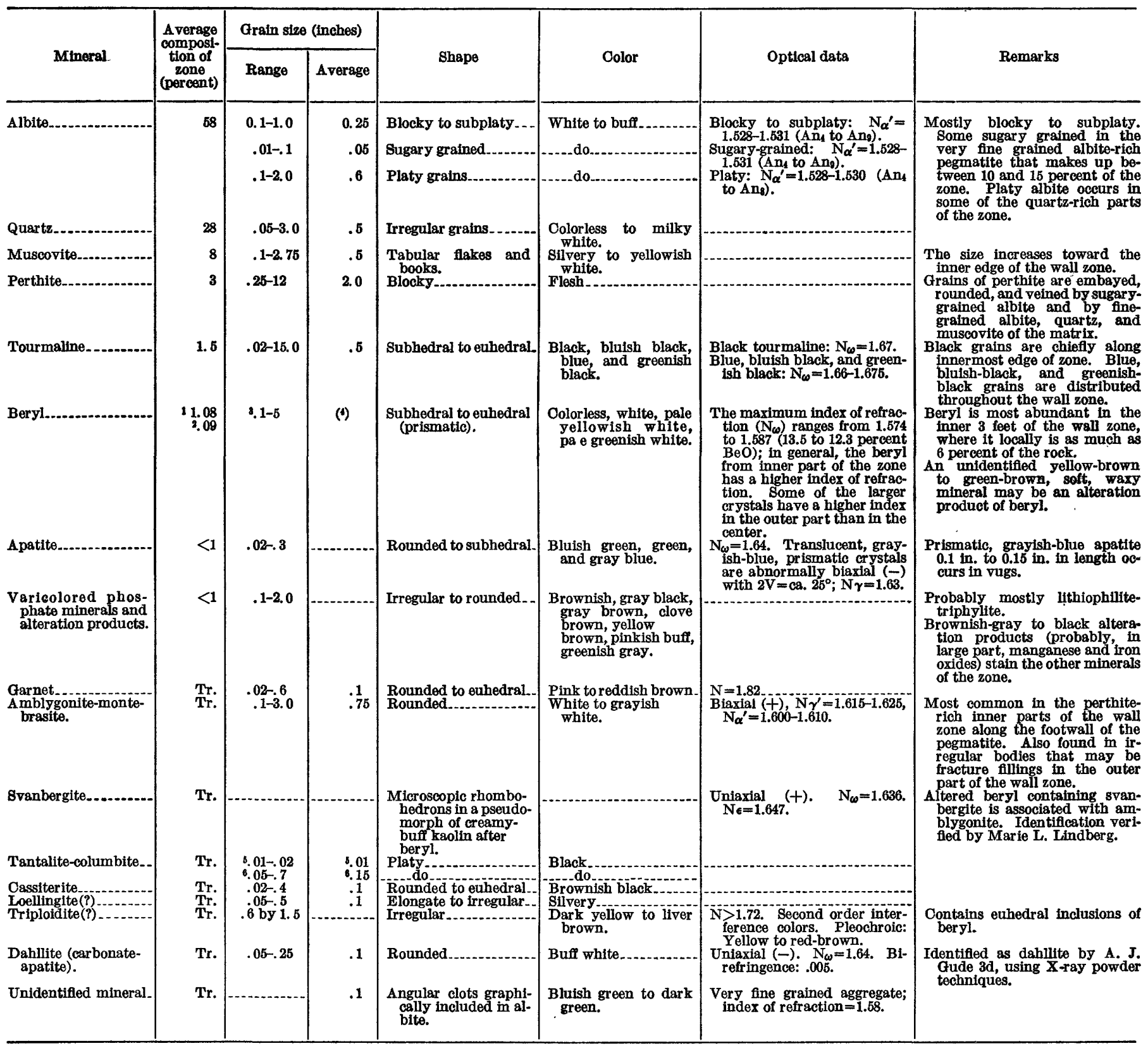

1 Outcrop. 2 Drill core.

Diameter.

0.75 (outer edge of zone) to 3 (inner edge of zone).

Thickness.

( Length. 
core. This change can also be correlated with the changes in albite and quartz content; plate 7 shows that beryl is most abundant in albite-rich layers.

The layers of the wall zone (pl. 7 and table 4) can be correlated from place to place, and a sequence of units can be constructed. Contacts between layers are generally gradational. Layers such as 4 and 9 listed in table 4 have somewhat sharper contacts that in places cut across adjacent layers. These may be fracture fillings, or they may have crystallized from segregation of fluids that were trapped by more rapidly crystallizing adjacent rocks.

The outermost layer of some parts of the wall zone consists of quartz-muscovite pegmatite similar to the border zone except that it is coarser grained. Ordinarily, however, the outermost layer is quartz-albite-muscovite pegmatite or albite-quartz-muscovite pegmatite.

The next layer is similar to the albite-quartz-muscovite pegmatite, but it also contains distinctive sugarygrained aggregates of albite (85 percent), quartz (10 percent), and accessory minerals. These aggregates form lenses and layers parallel to the larger layers.

This layer is followed in many places by an albiteperthite-quartz layer that contains coarse perthite crystals in a groundmass of albite, quartz, and muscovite. It is chiefly fine to medium grained, but also contains sugary-grained albite-quartz aggregates.

Another nonperthitic layer containing sugarygrained albite and quartz is next in the sequence, and is followed in turn by layers containing fine- to mediumgrained albite, quartz, and muscovite (layers 7 and 8 of table $4 ; 9$ of pl. 7).

A perthite-bearing layer containing quartz, albite, and muscovite is next in the sequence both in the drill holes (pl. 7) and in the open pit (table 4). It is followed by still another fine- to medium-grained albite-quartzmuscovite pegmatite. The innermost layer of the wall zone is quartz-albite pegmatite, recognized only in a few places.

Another type of layer, not shown in plate 7 or table 4, consists of medium-grained lenses of quartz-rich pegmatite that rarely exceed 1 foot in thickness and 3 feet in length. A lens of this type in the main pit has an average grain size of 1.25 inches, and contains quartz (60 percent), muscovite (24 percent), albite (14 percent), beryl ( 1 percent), and sparse accessory minerals.

It can be expected that further detailed study will lead to the recognition of still more layers in the sequence. Each of the layers 2 to 10 listed in table 4, and 4 to 11 shown in plate 7 may be repeated more times than shown here.

Optical data and descriptions of individual minerals of the wall zone are included in table 6 . The albite $\left(A_{4-9}\right)$ in all parts of the zone, except the sugary- grained aggregates, is blocky to subplaty. The average grain size is about 0.25 inch. In a few places, such as layer 7 of table 4 , the albite $\left(\mathrm{An}_{4-8}\right)$ is platy and has an average grain size of $0.6 \mathrm{inch}$. The anorthite content decreases toward the inner part of the wall zone (pl. 7), but there is overlap and repetition that presumably is related to the repetition of the layers and to crosscutting relationships between these units.

Beryl is most abundant in albite-rich layers, especially in the inner part of the wall zone where it locally forms as much as 6 percent of the rock (pl. $3 B$ ). The average size increases from 0.75 inch in diameter in the outer part of the wall zone to 3 inches at the inner edge. The $\mathrm{BeO}$ content of the beryl decreases toward the inner part of the zone, but like the anorthite content of albite, there is overlap and repetition. In the drill holes (pl. 7) the $\mathrm{BeO}$ content of beryl decreases from layers 2 to 5 , and increases in layer 6 , which contains sugary-grained albite-quartz aggregates; it decreases again in the perthite-rich pegmatite of layer 7 , which probably is a segregation; and increases in the albitequartz pegmatite of layer 8 . Beryl with the lowest $\mathrm{BeO}$ content occurs in quartz-albite pegmatite of layer 12 . The index of refraction of beryl from the outer part of some of the larger crystals is higher than for beryl from the center of the crystals.

Crystals of black tourmaline, as much as 10 inches in diameter, are most abundant near the contact with the first intermediate zone. Grains of blue, bluishblack, and greenish-black tourmaline, as much as 1 inch in length, and bluish-green grains of apatite, 0.02 to 0.3 inch in length, are distributed throughout the wall zone.

Varicolored phosphate minerals occur in irregular to rounded masses as much as 2 inches in diameter. Most of these minerals are probably members of the lithiophilite-triphylite group. One dark-yellow "to reddishbrown mass may be triploidite(?). Small rare buffwhite grains are dahllite. ${ }^{4}$ Brownish-gray to black alteration products of the phosphate minerals, probably manganese and iron oxides, stain the other minerals of the zone in irregular streaks and patches.

Reddish-brown grains of garnet, black plates of tantalite-columbite, and brownish-black grains of cassiterite are sparsely distributed in the wall zone. Rounded grains of amblygonite-montebrasite, 0.1 to 3 inches in diameter, are most common in perthite-rich layers along the footwall parts of the zone, but have also been observed in small irregular bodies that are possibly fracture fillings in the outer part of the zone. Optical data indicate that this mineral is relatively high in the hydroxyl group, and is probably on the montebrasite side of the series. Microscopic rhom-

4 Identified by A. J. Gude 3d, U. S. Ceological Survey, by X-ray powder technique. 
bohedrons of svanbergite occur in a pseudomorph of creamy-buff kaolin after beryl that is associated with a grain of amblygonite-montebrasite at the base of the pinnacle in the main opencut (pl. 4). An unidentified bluish- to dark-green soft mineral occurs as 0.1-inch angular clots that are graphically included in albite; microscopically the unidentified mineral is very fine grained and has an index of refraction of about 1.578 .

Cleavelandite-quartz-muscovite pegmatite (zone 3, first intermediate zone).-This zone consists of cleavelanditequartz-muscovite pegmatite that forms a less complete shell than the wall zone; on the map (pl. 4) and in section (pl. 6), however, it reflects the overall shape and structure of the pegmatite body almost as well as the wall zone. Where the wall zone is locally absent, zone 3 is separated from schist by only the border zone. The inner margin of zone 3 is adjacent to zone 5 tbroughout most of the pegmatite body, but in the upper parts of the northeastern limbs of the pegmatite, it lies between the wall zone and the downward-tapering zone 4 (pls. 4 and 6). Zone 3 pinches out upward over most of the crestal parts of the pegmatite; possibly it grades upward into zone 4 in some of the unexposed parts of the pegmatite.

In most exposures, the contacts of zone 3 are clearly defined, because the muscovite content is relatively high in sharp contrast to the lower content of adjacent units. Locally, where the contact is gradational for several feet, a cutoff at 10 percent muscovite was used to map the contact with zones 2 and 5 .

The thickness of zone 3 is as much as 15 feet; the average is about 5 feet in the footwall and about 1.5 feet in the hanging wall (pl. 6). This zone has a medium-grained pegmatitic texture; the size varies greatly but individual grains average about 2.25 inches. Locally many large aggregates of cleavelandite or large books of muscovite have a coarse-grained pegmatitic texture.

The average mineralogic composition of zone 3 and detailed descriptive data are given in table 7 . Locally the proportions of the minerals differ widely. For example, the large exposure between sections $A-A^{\prime}$ and $B-B^{\prime}$ (pl. 4) contains areas of about 5 square feet that have 55 percent cleavelandite, 19 percent quartz, 15 percent beryl, and 10 percent muscovite; yet the remaining area contains a relatively high proportion of muscovite-as much as 50 percent-and less than 1 percent beryl. Near the west end of the main pit (pl. 4) zone 3 contains 54 percent muscovite, 25 percent cleavelandite, 20 percent quartz, and 1 percent beryl. Generally muscovite is most abundant in the thick parts of the zone near the keel of the pegmatite (pl. 6). Locally, perthite constitutes as much as 5 percent of the zone.

Aggregates of cleavelandite $\left(\mathrm{An}_{4-8}\right)$ are as much as 18 inches in diameter, but average about 4 inches. Individual plates average about 1 inch in length and about 0.02 inch in thickness.

The largest book of muscovite observed is 3 feet in diameter, but the average size is about 5 inches; aggregates of books are commonly 2 to 3 feet in diameter. Nearly all the muscovite has herringbone and wedge structures, and some is strongly ruled.

White, yellowish- and greenish-white beryl occurs as prismatic euhedral crystals, as hexagonal, tapered skeletal crystals ("shells") alternating with thin layers of cleavelandite, and as anhedral masses. Beryl crystals average about 3 inches in diameter and are 26 inches in maximum length. $\mathrm{N}_{\omega}$ ranges from 1.575 to 1.584 , indicating that the $\mathrm{BeO}$ content ranges from 12.6 to 13.5 percent. The outer parts of many crystals and of anhedral masses have higher indices and lower $\mathrm{BeO}$ content than the centers.

Flesh-colored perthite grains, 0.5 to 12 inches across, occur sparsely in the outermost part of the zone, especially near perthite-rich parts of the wall zone. Larger perthite crystals, as much as 20 inches across, occur near the inner contact of the zone where it grades into perthite-cleavelandite-quartz pegmatite of zone 4 .

Bluish-black to black, euhedral to subhedral grains of tourmaline, as much as 2.5 inches in length, commonly occur along the grain boundaries between cleavelandite and muscovite. Black plates of tantalite-columbite, as much as 4 inches in length, are intergrown with cleavelandite. Brownish-black grains of cassiterite, 0.05 to 0.65 inch in diameter, occur along the edges of muscovite books and form inclusions in beryl and cleavelandite. Rounded grains of amblygonite-montebrasite, as large as 3 inches, are sparsely distributed near the inner edge of the zone. Dark-brown irregular masses of phosphate minerals (probably chiefly members of the lithiophilite-triphylite group), reddish-brown to pink grains of garnet, buff to silvery grains of loellingite(?), bluish grains of vivianite(?), and white grains of dahllite are the more rare constituents of zone 3 .

Perthite-cleavelandite-quartz pegmatite (zone 4, second intermediate zone).-Perthite-cleavelandite-quartz pegmatite forms a hood in the upper part of the northeastern limbs of the pegmatite (pl. 4). The shape of zone 4 in cross section (pl. 6) is that of an asymmetric crescent, tilted to the northeast. It is as much as 35 feet thick near the crest, but pinches out downdip. The zone is absent both in the footwall parts of the pegmatite and on the hanging-wall side of westwarddipping limbs. 
TaBLE 7.-Mineralogy of cleavelandite-quartz-muscovite pegmatite (zone 8, first intermediate zone), Peerless pegmatite

\begin{tabular}{|c|c|c|c|c|c|c|c|}
\hline \multirow{2}{*}{ Mineral } & \multirow{2}{*}{$\begin{array}{l}\text { Average } \\
\text { composi- } \\
\text { tion of } \\
\text { zone } \\
\text { (percent) }\end{array}$} & \multicolumn{2}{|c|}{ Grain size (inches) } & \multirow{2}{*}{ Shape } & \multirow{2}{*}{ Color } & \multirow{2}{*}{ Optical data } & \multirow{2}{*}{ Remarks } \\
\hline & & Range & Average & & & & \\
\hline Cleavelandite....- & 40 & $0.2-3.0$ & 1.0 & Platy & $\begin{array}{l}\text { White to grayish } \\
\text { white. }\end{array}$ & $\begin{array}{l}\mathrm{N}_{a^{\prime}} \text { ranges from } 1.528 \text { to } 1.530 \\
\left(\mathrm{An}_{4} \text { to } \mathrm{An}_{8}\right) \text {. }\end{array}$ & $\begin{array}{l}\text { A verage thickness of platy grains } \\
\text { is } 0.02 \text { inch but av erage length } \\
\text { is } 1.0 \text { inch. Aggregates of } \\
\text { plates are as much as } 18 \text { inches } \\
\text { in diameter, but the average } \\
\text { size of such aggregates is } 4 \\
\text { inches. }\end{array}$ \\
\hline $\begin{array}{l}\text { Quartz } \\
\text { Muscovite }\end{array}$ & $\begin{array}{l}29 \\
28\end{array}$ & $\begin{array}{l}.1-4.5 \\
.1-36.0\end{array}$ & $\begin{array}{l}1.5 \\
5.0\end{array}$ & $\begin{array}{l}\text { Irregular } \\
\text { Books and fiakes................ }\end{array}$ & $\begin{array}{l}\text { Colorless to milky....- } \\
\text { Yellowish silvery.... }\end{array}$ & - & $\begin{array}{l}\text { Aggregates commonly } 2 \text { to } 3 \text { feet } \\
\text { in diameter. A bundant her- } \\
\text { ringbone and wedge structure } \\
\text { and some ruling. Punch and } \\
\text { sheet mica are rare. }\end{array}$ \\
\hline Beryl..... & $\left\{\begin{array}{l}11.46 \\
1.93 \\
1.7\end{array}\right.$ & $2.5-26.0$ & ${ }^{3} \mathbf{3}$ & $\begin{array}{l}\text { Chiefly subhedral to } \\
\text { euhedral (pris- } \\
\text { matic), but less } \\
\text { commonly anhe- } \\
\text { dral. Also as } \\
\text { tapered, irregularly } \\
\text { hexagonal, skeletal } \\
\text { crystals containing } \\
\text { thin layers of cleave- } \\
\text { landite. }\end{array}$ & $\begin{array}{l}\text { White, yellowish } \\
\text { white, and greenish } \\
\text { white. }\end{array}$ & $\begin{array}{l}\mathrm{N}_{\omega}=1.575 \text { to } 1.584 \text { (13.5 to } 12.6 \\
\text { percent BeO), Outer parts } \\
\text { of crystals have higher in- } \\
\text { dices than the centers. }\end{array}$ & $\begin{array}{l}\text { Beryl forms as much as } 15 \text { percent } \\
\text { of small cleavelandite-rich } \\
\text { parts of the zone. }\end{array}$ \\
\hline Perthite........... & $<1$ & 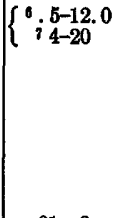 & $\begin{array}{r}63 \\
710\end{array}$ & Blocky & Flesh......... & & $\begin{array}{l}\text { Perthite is in the outermost part } \\
\text { of the zone where it occurs near } \\
\text { perthite-rich parts of the wall } \\
\text { zone. Larger and more abun- } \\
\text { dant perthite grains occur near } \\
\text { the inner contact of the zone } \\
\text { where it grades into the per- } \\
\text { thite-cleavelandite-quartz peg- } \\
\text { matite of the second intermedi- } \\
\text { ate zone. }\end{array}$ \\
\hline Apatite & $<1$ & $\begin{array}{l}.01-.3 \\
.01-2.5\end{array}$ & $\begin{array}{l}.1 \\
.5\end{array}$ & $\begin{array}{l}\text { Rounded to elongate } \\
\text { Subhedral to euhedrai. }\end{array}$ & $\begin{array}{l}\text { Bluish green } \\
\text { Bluish black, black, } \\
\text { and greenish black. }\end{array}$ & Bluish black: $\mathrm{N}_{\gamma}=1.66$ & $\begin{array}{l}\text { Commonly occurs along grain } \\
\text { boundaries between cleave- } \\
\text { landite and muscovite. }\end{array}$ \\
\hline $\begin{array}{l}\text { Tantalite-columbite. } \\
\text { Cassiterite........... }\end{array}$ & $<1$ & $.2-4.0$ & .25 & $\begin{array}{l}\text { Platy } \\
\text { Rounded to subhedral }\end{array}$ & $\begin{array}{l}\text { Black. } \\
\text { Brownish black......... }\end{array}$ & - & $\begin{array}{l}\text { Intergrown with cleavelandite. } \\
\text { Occurs along the edges of musco. } \\
\text { vite books and forms inclusions } \\
\text { in beryl and cleavelandite. }\end{array}$ \\
\hline $\begin{array}{l}\text { Amblygonite-monte- } \\
\text { brasite. }\end{array}$ & Tr. & $.3-3.0$ & 1 & Rounded to irregular.- & Grayish white............. & $\begin{array}{l}\text { Biaxdal }(+), \mathrm{N}_{\gamma^{\prime}}=1.62, \mathrm{~N}_{\mathrm{a}^{\prime}}= \\
\text { 1.61. }\end{array}$ & $\begin{array}{l}\text { Sparsely distributed near inner } \\
\text { edge of zone. Commonly has } \\
\text { a white to buff-white dusty } \\
\text { coating. More rarely bordered } \\
\text { by fine muscovite grains ( } 0.25 \\
\text { inch). }\end{array}$ \\
\hline $\begin{array}{l}\text { Varicolored phos- } \\
\text { phate minerals. }\end{array}$ & Tr. & $.1-1.5$ & -....... & Irregular.... & Mostly dark brown & & $\begin{array}{l}\text { Erratically distributed. Prob- } \\
\text { ably consists chiefly of lithlo- } \\
\text { philite-trinhylite. }\end{array}$ \\
\hline Garnet_.................. & Tr. & $+\infty$ & $<.25$ & Rounded... & Reddish brown to & & Occurs near schist contact. \\
\hline $\begin{array}{l}\text { Loellingite(?) } \\
\text { Vivianite(?) }\end{array}$ & $\begin{array}{l}\text { Tr. } \\
\text { Tr. }\end{array}$ & & $<.5$ & Irregular... & $\begin{array}{l}\text { Buff to silvery... } \\
\text { Blue. }\end{array}$ & $\mathrm{N}_{\gamma}=1.65 . \quad$ Pleochroic: deep & Borders loellingite(?). \\
\hline $\begin{array}{l}\text { Dahllite (carbonate- } \\
\text { apatite). }\end{array}$ & Tr. & $.05-.5$ & 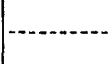 & & $\begin{array}{l}\text { White to grayish } \\
\text { white. }\end{array}$ & $\begin{array}{l}\mathrm{N}_{\omega}=1.635 . \quad B \text { irefringence: } \\
.005 .\end{array}$ & \\
\hline
\end{tabular}

1 Outcrop. 'Iength. Diameter. 'Drill core. B Average. Outer part of zone. 'Inner part of zone.

The outer edge is in contact with the wall zone near the crest of the pegmatite, but at depth the downwardtapering zone 4 is separated from wall zone by the upward-tapering zone 3 . These two units grade into each other. A cutoff at 5 percent perthite is used to mark the contact.

Individual grains average about 10 inches in length, but crystals of perthite are as long as 20 feet. Perthite crystals average about 2 feet in length, and aggregates of cleavelandite-quartz matrix are as large as 4 feet; thus the overall appearance of most exposures is that of very coarse pegmatite.

The average mineralogic composition of zone 4 and detailed descriptive data are presented in table 8 . In upper and outer parts of the zone, perthite constitutes as much as 65 percent of the unit; perthite decreases in abundance toward the interior of the pegmatite.

White to flesh-colored blocky crystals of perthite are in a matrix composed of massive quartz and aggregates of white cleavelandite. Individual plates of cleavelandite average about 1 inch in length, but aggregates are commonly 4 inches in diameter. Masses of quartz are as much as 18 inches across but average about 1.75 inches. Books of yellowish-silvery muscovite, as much as 6 inches in diameter, are scattered irregularly throughout the matrix. A few white euhedral crystals of beryl, as much as 30 inches in diameter and 50 inches in length, are distributed erratically in the zone. Bluish-black tourmaline occurs as irregular shells and masses along grain boundaries in the cleavelanditequartz matrix. Rounded bluish-green grains of apatite (0.05 inch) are present in small quantities.

Cleavelandite-quartz pegmatite (zone 5 , third intermediate zone).-This zone forms a complete shell that underlies the hood-shaped zone 4 and completely surrounds zones 6 and 7 . In the keelward parts of the 


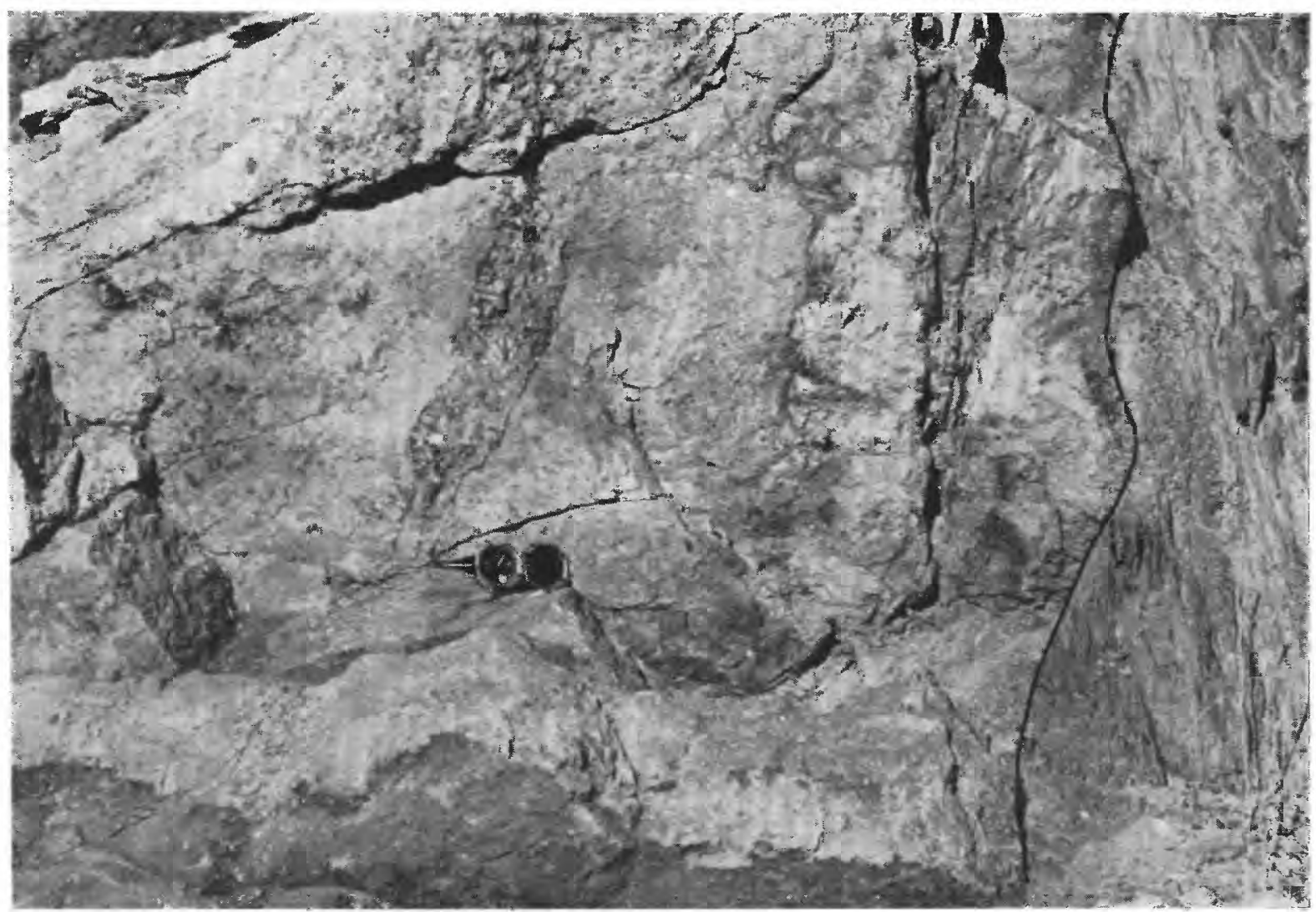

$A$, LAYERS IN THE WALL ZONE.

Schist contact on the right. South of area shown in plate $2 A$.

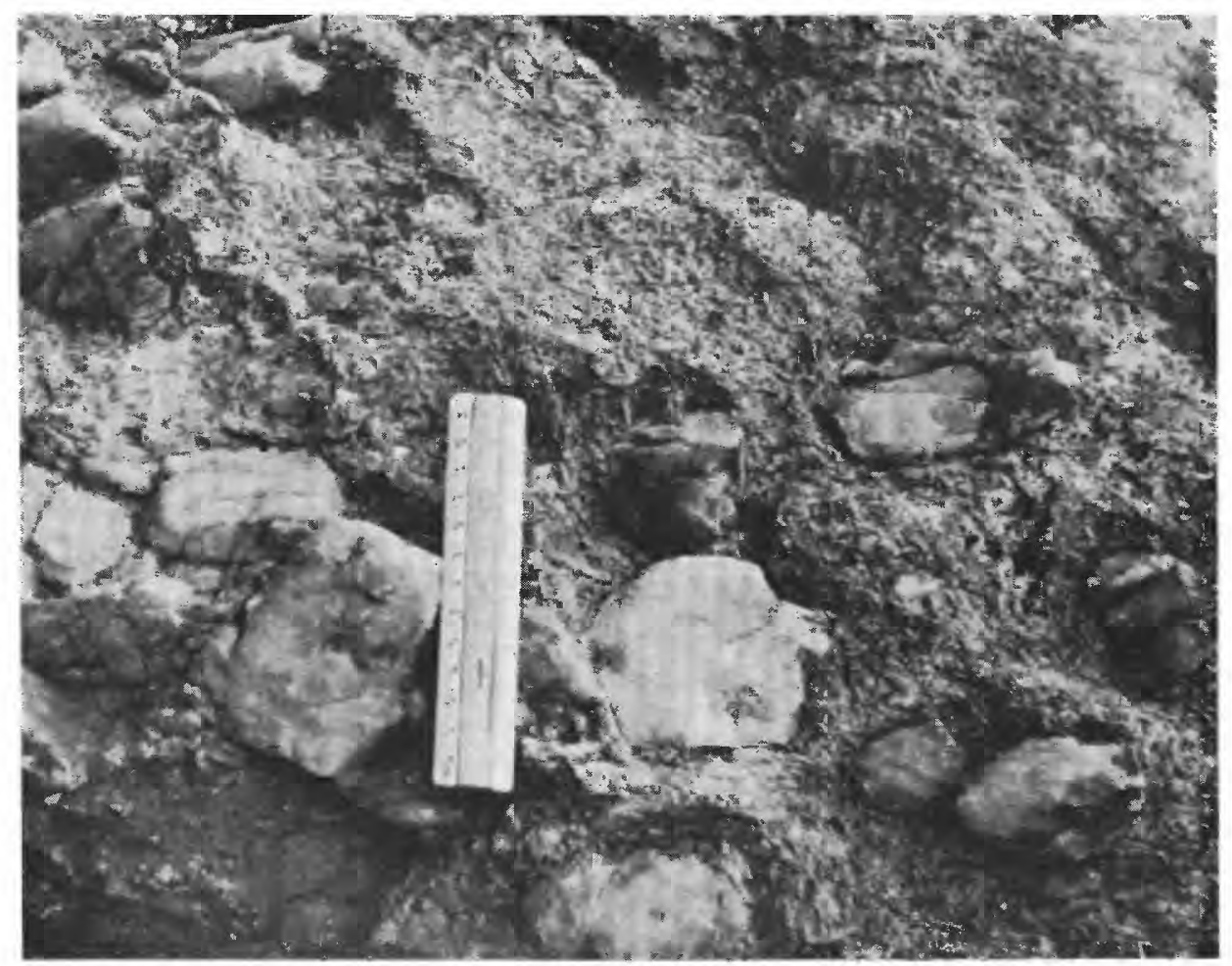

$B$, BERYL IN THE WALL ZONE.

Beryl in albite-rich pegmatite of the inner part of wall zone near contact with zone 3. 

TABLE 8.-Mineralogy of perthite-cleavelandite-quartz pegmatite (zone 4, second intermediate zone), Peerless pegmatite

\begin{tabular}{|c|c|c|c|c|c|c|}
\hline \multirow{2}{*}{ Mineral } & \multirow{2}{*}{$\begin{array}{l}\text { Average } \\
\text { composi- } \\
\text { tion of } \\
\text { zone } \\
\text { (percent) }\end{array}$} & \multicolumn{2}{|c|}{ Grain size (inches) } & \multirow{2}{*}{ Shape } & \multirow{2}{*}{ Color } & \multirow{2}{*}{ Remarks } \\
\hline & & Range & A verage & & & \\
\hline $\begin{array}{l}\text { Perthite } \\
\text { Cleavelandite. }\end{array}$ & $\begin{array}{l}40 \\
30\end{array}$ & $1-240$ & $\begin{array}{c}24 \\
1.0\end{array}$ & $\begin{array}{l}\text { Blocky } \\
\text { Platy }\end{array}$ & $\begin{array}{l}\text { White to flesh } \\
\text { White to grayish white }\end{array}$ & A verage size of cleavelandite aggregates is \\
\hline $\begin{array}{l}\text { Quartz } \\
\text { Muscovite. }\end{array}$ & $\begin{array}{r}23 \\
6\end{array}$ & $.25-18$ & $\begin{array}{l}1.75 \\
2.5\end{array}$ & Brregular & $\begin{array}{l}\text { Colorless to milky white } \\
\text { Yellowish silvery }\end{array}$ & \\
\hline Beryl........ & $<.5$ & $\left.\begin{array}{l}1 ?-50 \\
2.5-30\end{array}\right\}$ & $\cdots$ & Euhedral & White............ & Erratically distributed. \\
\hline Tourmaline. & $<1$ & - & & Irregular shells and masses....- & Bluish black..... & Commonly occurs along grain boundaries \\
\hline A patite.... & $<1$ & & .05 & Rounded.......... & Bluish green....... & \\
\hline
\end{tabular}

1 Length. 2 Diameter.

pegmatite, zone 5 is bounded on the outside by zone 3 (pl. 6). In a few places, especially at the crest of the northwestern part of the pegmatite (pl. 6), zone 5 is in contact with the wall zone. Locally, irregular replacement bodies of muscovite-cleavelandite pegmatite and lithia mica-cleavelandite-quartz pegmatite cut zone 5 .

The maximum thickness of zone 5 is 35 feet or more, but in most parts of the pegmatite it ranges from 15 to 30 feet (pl. 6).

Individual grains average about 1.5 inches, but the size of aggregates varies widely. Aggregates of cleave- landite are as much as 5 feet in diameter, though the average is about 4 inches.

The average mineralogic composition of zone 5 and detailed descriptive data are given in table 9. Generally, the outer third of this zone is relatively rich in quartz-as much as 70 percent quartz and 23 percent cleavelandite in some exposures. The inner part is relatively rich in cleavelandite; it contains as much as 62 percent cleavelandite and 30 percent quartz in some places.

The cleavelandite $\left(\mathrm{An}_{4}\right)$ occurs in white to grayish-

TABLE 9.-Mineralogy of cleavelandite-quartz pegmatite (zone 5, third intermediate zone), Peerless pegmatite

\begin{tabular}{|c|c|c|c|c|c|c|c|}
\hline \multirow{2}{*}{ Mineral } & \multirow{2}{*}{$\begin{array}{l}\text { Average } \\
\text { compo- } \\
\text { sition } \\
\text { of zone } \\
\text { (percent) }\end{array}$} & \multicolumn{2}{|c|}{ Grain size (inches) } & \multirow{2}{*}{ Shape } & \multirow{2}{*}{ Color } & \multirow{2}{*}{ Optical data } & \multirow{2}{*}{ Remarks } \\
\hline & & Range & A verage & & & & \\
\hline Cleavelandite. . & 45 & $0.2-3.0$ & $\begin{array}{ll}1 & 0.02 \\
2 & 1.0\end{array}$ & Platy..... & White to grayish white.. & $\mathrm{N}_{\alpha^{\prime}}$ is $1.528\left(\mathrm{An}_{4}\right) \ldots$ & $\begin{array}{l}\text { Occurs chiefly as aggregates of } \\
\text { diversely oriented or radiating } \\
\text { cleavelandite plates, many of } \\
\text { which are curved. These ag- } \\
\text { gregates are as much as } 5 \text { feet } \\
\text { in diameter; the average is } \\
\text { about } 4 \text { inches. }\end{array}$ \\
\hline $\begin{array}{l}\text { Quartz } \\
\text { Muscovite........... }\end{array}$ & $\begin{array}{r}45 \\
6\end{array}$ & $.25-12$ & $\begin{array}{l}1.75 \\
3.0\end{array}$ & $\begin{array}{l}\text { Irregular. } \\
\text { Books and flakes. }\end{array}$ & $\begin{array}{l}\text { Colorless to milky white. } \\
\text { Silvery yellow }\end{array}$ & & Wedge and herringbone struc- \\
\hline $\begin{array}{l}\text { Varicolored phosphate } \\
\text { minerals. }\end{array}$ & 1 & $.2-6.0$ & .75 & Irregular............. & Dark brown to purple.. & & $\begin{array}{l}\text { the muscovite is strongly ruled. } \\
\text { Probably consist largely of lithio- } \\
\text { philite-triphylite and their } \\
\text { alteration products. Irregular } \\
\text { aggregates of these minerals } \\
\text { associated with strongly stained } \\
\text { cleavelandite, quartz, and mus- } \\
\text { covite form dark-colored, pod- } \\
\text { shaped to irregular masses as } \\
\text { much as } 3 \text { feet in diameter. }\end{array}$ \\
\hline $\begin{array}{l}\text { Amblygonite - mon te- } \\
\text { brasite. }\end{array}$ & $.5-1$ & $.2-36.0$ & 6.0 & Rounded to subhedral.. & Grayish white............ & $\begin{array}{c}\text { Biaxial }(+) ; \underset{2}{\text { commonly }} \\
2 \mathrm{~V}>75^{\circ} .\end{array}$ & $\begin{array}{l}\text { Commonly coated by a buff- } \\
\text { white al teration product. } \\
\text { Veined and embayed by } \\
\text { quartz. }\end{array}$ \\
\hline Beryl & .5 & 3. $3-15$ & 3 & $\begin{array}{l}\text { Euhedcal (prismatic). } \\
\text { Also anhedral masses } \\
\text { in tergrown w ith } \\
\text { cleavelandite, quartz, } \\
\text { and muscovite. }\end{array}$ & $\begin{array}{l}\text { White, pale green; some } \\
\text { semitransparent. }\end{array}$ & $\begin{array}{c}\mathrm{N}_{\omega}=1.584-1.587(12.6- \\
12.3 \text { percent } \mathrm{BeO})\end{array}$ & $\begin{array}{l}\text { Most abundant in the outer part } \\
\text { of the zone, but the distribu- } \\
\text { tion is irregular. }\end{array}$ \\
\hline Tantalite-columbite & $<1$ & $\left\{\begin{array}{l}2.25-4.0 \\
1.01-.15\end{array}\right\}$ & $\begin{array}{ll}2.8 \\
1.01\end{array}$ & Platy & Black & & Commonly between plates of \\
\hline Apatite & $<1$ & $.2-6.0$ & .6 & Anhedral to subhedral. & $\begin{array}{l}\text { Pale green to dark bluish } \\
\text { green. }\end{array}$ & $\begin{array}{l}N_{\omega}=1.654 . \quad N_{e^{\prime}}=1.651 . \\
\text { One specimen bas } \\
2 V>10^{\circ}\end{array}$ & 0us \\
\hline Tourmaline ...... & $<1$ & - & .2 & Euhedral & $\begin{array}{l}\text { Pale blue } \\
\text { Bluish black........... }\end{array}$ & $\begin{array}{l}N_{\omega}=1.66 . \\
N_{\omega}=1.66-1.67\end{array}$ & $\begin{array}{l}\text { Aggregates are commonly } 0.75 \\
\text { inch in diameter. }\end{array}$ \\
\hline Cassiterite & $<1$ & $.02-.75$ & .25 & $\begin{array}{l}\text { Rounded, subhedral, } \\
\text { and euhedral. }\end{array}$ & Brownish black & 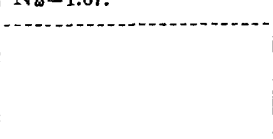 & $\begin{array}{l}\text { Most common along grain bound- } \\
\text { aries between muscovite and } \\
\text { cleavelandite; also occurs as } \\
\text { inclusions in cleavelandite, } \\
\text { amblygonite-montebrasite, } \\
\text { muscovite, and quartz. }\end{array}$ \\
\hline
\end{tabular}

1 Thickness. 2 Length. 3 Diameter. 
white, platy grains that average about 1 inch in length and 0.02 inch in thickness. The cleavelandite plates are both flat and curved. They occur as radiating clusters and as aggregates of diversely oriented plates. In the quartz-rich parts of the zone, cleavelandite forms irregular streaks and clots surrounded by massive quartz. The contact with zone 6 is commonly marked by a cleavelandite-rich layer 1 to 3 feet thick.

Books and flakes of silvery-yellow muscovite range in size from 0.1 to 20 inches. The distribution of larger books is very irregular. As in zone 3 , the muscovite has abundant herringbone and wedge structures.

Grayish-white rounded grains of amblygonite, as much as 3 feet in diameter, commonly are coated by buff-white alteration products and are veined and embayed by quartz. Optical data indicate that this is montebrasite of about the same composition as in outer zones. Irregular aggregates of dark-brown to purplish phosphate minerals-probably lithiophilitetriphylite - are intergrown with variable amounts of strongly stained, intergrown cleavelandite, quartz, and muscovite to form dark-colored, pod-shaped to irregular masses that are as much as 3 feet in diameter.

Beryl is most abundant in the outer parts of the zone, but the distribution is irregular. White, faintly greenish, and semitransparent beryl occurs both as prismatic euhedral crystals and as anhedral masses that are intimately intergrown with cleavelandite. The diameter of grains of beryl ranges from 0.3 to 15 inches; $\mathrm{N}_{\omega}$ ranges from 1.584 to 1.587 , indicating a $\mathrm{BeO}$ content of 12.3 to 12.6 percent. Thin black plates of tantalitecolumbite are interleaved with cleavelandite. Palegreen to dark-bluish anhedral masses of apatite occur irregularly in this zone. Euhedral grains of bluishblack tourmaline form aggregates that are commonly about 0.75 inch in diameter, but isolated grains of paleblue and black tourmaline also occur in the zone. Brownish-black grains of cassiterite, having an average grain size of about 0.25 inch, occur most commonly along grain boundaries between muscovite and cleavelandite, but are also found as inclusions in cleavelandite, amblygonite-montebrasite, quartz, and muscovite.

Near the bottom of diamond-drill hole 3 (pl. 6), vugs as long as 0.75 inch are lined with quartz crystals; other small vugs are filled with limonite. In this drill hole, the lower 8.7 feet was in an open hole that is probably a vug or a solution cavity in the main fault zone; abandoned mine workings are not known to exist in this part of the pegmatite.

Quartz-microcline pegmatite and quartz pegmatite (zones $6 a$ and $6 b$, fourth intermediate zone; fracture fillings).Zone 6 consists of quartz pegmatite and a hood of quartz-microcline pegmatite. This hood overlies both the quartz pegmatite and the lithia mica-bearing core and replacement unit (pls. 4 and 6). Quartz pegmatite is the central unit of some parts of the pegmatite, as in the eastern part of section $E-E^{\prime}$ (pl. 6), and in section $A-A^{\prime}$ (pl. 6).

The quartz pegmatite may be as much as 40 feet thick and the quartz-microcline hood may also reach a thickness of about 40 feet.

The quartz-microcline pegmatite has a very coarse pegmatitic texture. The minerals are quartz (59 percent), microcline ( 40 percent), and lithia mica $(<1$ percent). Colorless to milky-white quartz occurs in masses as much as 30 feet in diameter, separating large crystals of flesh-colored microcline, as large as 15 by 10 by 6 feet. Perthite was not recognized in this zone. Megascopic gridiron twinning was observed in some of the microcline. Very fine grained (less than 0.05 inch) yellowish-green lithia mica is disseminated along some cleavage surfaces and cracks in the microcline, and may be genetically related to lithia mica of the replacement unit.

Quartz pegmatite consists essentially of massive, milky-white to colorless quartz (99 percent); the minor accessory minerals include spodumene $(<1$ percent), dark-brown phosphate minerals ( $<1$ percent), and beryl (trace). Remnants of two spodumene crystals, 24 and 6 inches in length, occur at the north end of this zone in the northwestern part of the pegmatite (pl. 4). Dark-brown phosphate minerals, probably lithiophilite-triphylite, are exposed as irregular clots, 2 to 8 inches across, in the southwestern limb of the pegmatite.

Three conspicuous quartz fracture-filling units ranging from 6 inches to 2 feet in thickness are exposed on the west side near the north end of the pegmatite (pl. 4). These units cut zones 1, 2, 3, and 5, but do not extend across the contact of pegmatite and schist. Smaller quartz fracture-filling units are exposed elsewhere in the pegmatite but are not large enough to be mapped. These fracture fillings all consist of massive milky quartz; no accessory minerals were observed.

Lithia mica-cleavelandite pegmatite (zone 7, core).Lithia mica-cleavelandite pegmatite forms the very small core of this pegmatite (pls. 4 and 6). The maximum thickness is probably about 15 feet; the longest dimension is down dip, and may be as much as 50 feet. The chief exposures are in the open pit near section $E-E^{\prime}$ (pl. 6).

The core has a very fine grained pegmatitic texture; the average grain size is about $0.1 \mathrm{inch}$. Aggregates of lithia mica and cleavelandite are much larger.

The minerals of the core include lithia mica (82 percent), cleavelandite (15 percent), quartz (1 percent), dark-brown phosphate minerals ( 1 percent), tantalitecolumbite ( $<1$ percent), and cassiterite $(<1$ percent). 
The innermost part of the core is composed almost exclusively of olive-green lithia mica, in grains averaging about 0.05 inch across; in the outer part of the core lithia mica is associated with cleavelandite, in 1-inch aggregates and thin veinlike stringers as much as 2 feet in length. Individual plates of cleavelandite commonly are 0.1 to 0.4 inch. Quartz grains are as much as 0.5 inch in diameter. Dark-brown phosphate minerals, probably lithiophilite-triphylite, occur in irregular clots as large as 8 inches. Cassiterite and tantalite-columbite are irregularly distributed in the core as grains generally less than 0.5 inch.

"Lithia mica" is a field name that has been used for mica occurring in other Black Hills pegmatites as finegrained olive-green aggregates differing greatly in appearance and habit from muscovite of outer zones. Presumably it also differs in chemical composition and structure. The lithia mica resembles lepidolite in habit and appearance, but not in color and lithia content. Data on mineralogic variations in Black Hills mica deposits are incomplete, and an accurate mineralogic name cannot be applied to this so-called lithia mica.

A purified sample of the lithia mica was studied by petrographic, X-ray, and spectrographic methods. The mica has the following optical properties: biaxial (-), $2 V=$ about $30^{\circ}$ (definitely $\left\langle 371_{2}^{\circ}\right.$ ), $\mathrm{N}_{\gamma}=1.593 \pm 0.001$, $\mathrm{N}_{\beta}=1.588 \pm 0.001$. The fusibility of the mica is about 2. A semiquantitative spectrographic analysis by P. J. Dunton and R. G. Havens, of the Geological Survey, gave the results shown in table 10 (data for zone 7). An X-ray powder diffraction photograph by A. J. Gude $3 \mathrm{~d}$ showed that the mica is muscovite in which the strongest lines are spaced as follows:

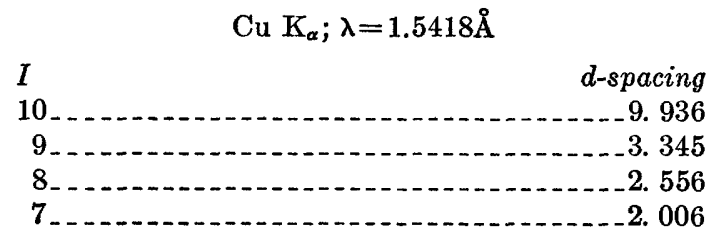

These results are in accord with the work of Levinson (1953, p. 101), who found that mica with less than about 3.3 percent $\mathrm{Li}_{2} \mathrm{O}$ has the normal muscovite structure. Mica from the core of the Peerless pegmatite containing 0.2 percent lithium is within the range of normal muscovite, according to Levinson's graphs (1953, figs. 4 and 5, p. 103).

Lithia mica-cleavelandite-quartz pegmatite (replacement unit).-The replacement unit extends outward from the core across all the intermediate zones (pls. 4 and 6). The shape of the unit is very irregular, and the size is not known. The main body of the replacement unit extends at least 30 feet from the core, but small parts of it are as much as 100 feet from the core.
The replacement unit is principally in zones 5 and 6 , but masses 1 to 3 feet in diameter occur in zones 3 and 4. The wall zone contains fracture fillings, 0.1 to 3 inches thick, filled with fine-grained grayish-yellow material that may be lithia mica, but otherwise there is no evidence that the wall zone contains minerals of the replacement unit.

The composition of the replacement unit differs greatly, depending on the zone replaced and upon the percentage of relict minerals. As much as 20 percent of some mapped exposures of this unit consists of unreplaced irregular-shaped relicts. In some parts of zone 5 replacement has produced a mottled rock containing irregular embayed clots of cleavelanditequartz pegmatite surrounded by the very fine grained lithia mica-cleavelandite pegmatite. Elsewhere replacement of this zone has resulted in a "bladed" texture, containing elongate (2 to 24 inches) tabular remnants of cleavelandite-quartz pegmatite separated by the very fine grained lithia mica-cleavelandite pegmatite. Masses of the replacement unit in quartzmicrocline pegmatite have a tabular shape that indicates fracture control.

Outside the mapped limits of the replacement unit, some lithia mica associated with cleavelandite occurs along minute fractures and as interstitial "aggregates in other units. These may be genetically related to the core and replacement unit.

Muscovite-cleavelandite pegmatite (replacement unit).The muscovite-cleavelandite replacement unit is exposed near the contact of zones 5 and 6 between sections $D-D^{\prime}$ and $E-E^{\prime}$ (pl. 4). The maximum thickness is nearly 40 feet. Pod-shaped to irregular masses of muscovite-cleavelandite pegmatite are exposed in zone 5 in the underground workings, but these masses are too small to be mapped.

The contacts are very irregular in detail. Muscovitecleavelandite pegmatite fills fractures in the quartz pegmatite, and extends outward from these fractures into massive quartz. Irregular to rounded relicts of quartz pegmatite are cut by muscovite-cleavelandite aggregates along the contact of these two units. The contacts with the cleavelandite-quartz pegmatite of zone 5 are equally complex and irregular. The form of the boundaries of this replacement unit indicates that it was controlled, in part, by an irregular network of fractures that formed after the consolidation of zone 6.

The minerals, excluding relict masses of partly replaced pegmatite, consist of muscovite (69 percent), cleavelandite (30 percent), apatite $(<1$ percent), tourmaline $(<1$ percent), tantalite-columbite $(<1$ percent), lithia mica ( $<1$ percent), cassiterite (trace), and beryl(?) (trace). Individual grains average about 0.2 inch in 


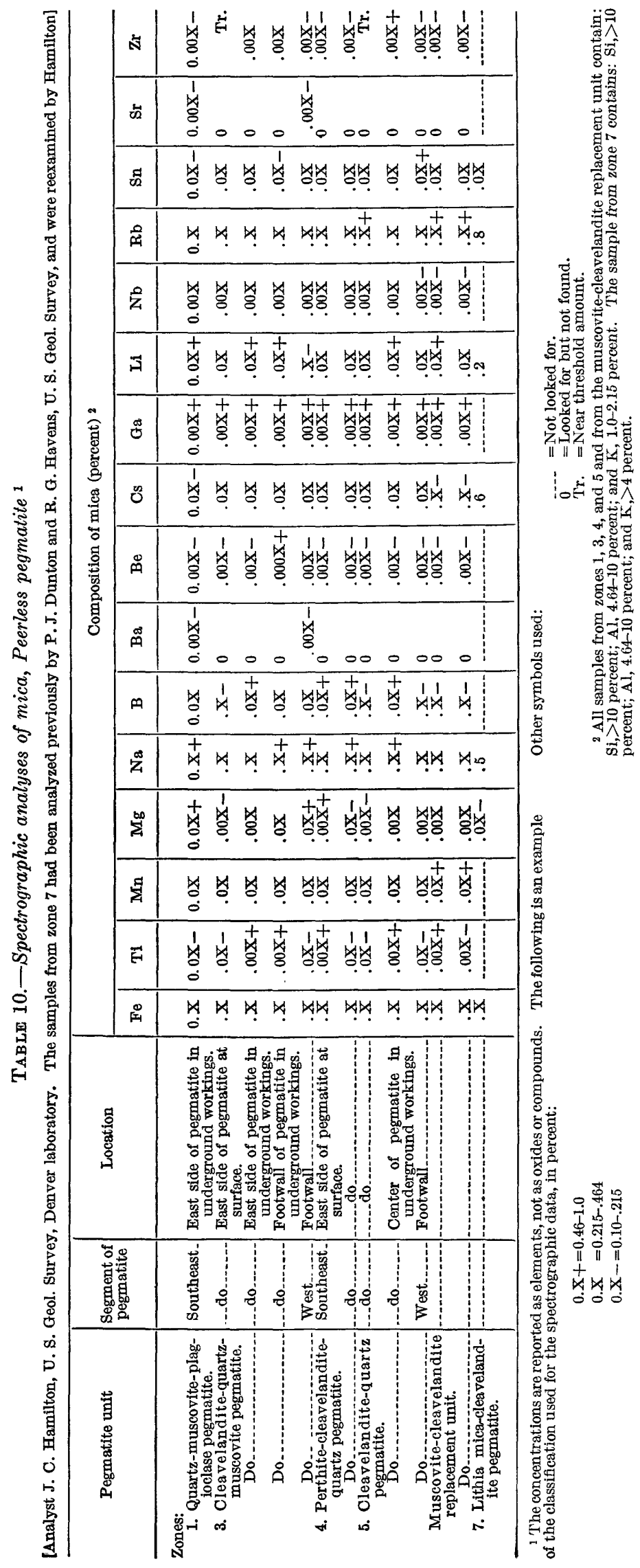


diameter. Buff-white plates of cleavelandite and flakes and books of silvery-yellow muscovite average about 0.2 inch, but are as large as 1 inch. The cleavelandite occurs in irregular streaks along gradational contacts with zones 5 and 6 , and is also disseminated through the replacement unit as irregular aggregates, as much as 1 inch in diameter. Small rounded grains of greenishblue apatite and black to bluish-black tourmaline are irregularly distributed throughout the unit. Plates of tantalite-columbite are as large as 1 by 3 inches, but generally are less than 0.5 inch.

Tourmaline-quartz pegmatite (fracture fillings).-Drusy fracture fillings of tourmaline-quartz pegmatite occur on the northwestward-trending fault just southwest of the large unmined pinnacle, and also along the main westward-trending fault northwest of this pinnacle (pls. 4 and 6). These faults must have formed after the consolidation of the core of the Peerless pegmatite because they cut all the zones, replacement bodies, and the core. On the other hand, the faults were formed before the consolidation of the tourmaline-quartz pegmatite because these fracture-filling units occur on slickensided surfaces of the faults and the drusy structure is undisturbed. These structural relationships indicate that the tourmaline-quartz fracture-filling units are not necessarily directly related in origin to the main mass of the Peerless pegmatite. The thickness of the fracture fillings ranges from 0.25 to 0.5 inch.

The minerals are tourmaline (90 percent) and quartz (10 percent). The average grain size is about 0.15 inch. The tourmaline is in pale-pink translucent prismatic crystals that range from 0.05 to 0.25 inch in length. Optically the tourmaline is colorless, uniaxial (-), $\mathrm{N}_{\omega}=1.632$. A few grains seem to be abnormally biaxial ( + ) with $2 \mathrm{~V}=10^{\circ}-40^{\circ}$. The quartz occurs in tiny colorless crystals similar in size to the tourmaline but less regularly distributed.

\section{VARIATION IN MICA COMPOSITION}

In order to determine the compositional differences in mica from other units of this pegmatite, a series of samples collected from five zones and from the muscovite-cleavelandite replacement unit was analyzed spectrographically (table 10). The results show that the content of cesium, rubidium, boron, and perhaps tin and manganese increases from the wall of the pegmatite inward. The lithium content of mica from zone 7 is 0.2 percent, but from all but one sample from other units it is $0.0 \mathrm{X}$ or $0.0 \mathrm{X}+$ percent. The magnesium and niobium content of mica shows a poorly defined tendency to decrease from the wall inward. Analyses of four samples from zone 3 indicate that in the lower parts of this zone the muscovite may contain more magnesium and lithium and less boron than muscovite in structurally higher parts of this zone.

\section{FAULTS}

A system of faults having westerly trends cuts all units of the Peerless pegmatite except the tourmalinequartz fracture-filling units. Most of these faults are normal, but a few are reverse. The dip is commonly between vertical and $70^{\circ} \mathrm{S}$; ; the fault that cuts quartz pegmatite and muscovite-cleavelandite pegmatite northwest of the unmined pinnacle dips $70^{\circ} \mathrm{N}$. (pls. 4 and 6$)$.

The main westward-trending fault on the north side of the large open pit is vertical near its east end, but dips $84^{\circ} \mathrm{S}$. on the west side of the pegmatite. The apparent displacement has been determined from the position of pegmatite units on either side of the fault. The south side is offset as much as 45 feet to the west; the maximum vertical offset is probably about 25 feet, down to the south. Branch faults have dips as low as $75^{\circ} \mathrm{S}$. or $82^{\circ} \mathrm{N}$.

A normal fault that dips $78^{\circ}-88^{\circ} \mathrm{SW}$. trends northwestward on the southwest side of the unmined pinnacle. The vertical offset is about 2 feet. Other faults shown on the maps (pls. 4, 5) similarly have small displacements.

\section{CFEMICAL COMPOSITION}

The chemical composition of the Peerless pegmatite has been determined by using successive geologic sections to compute the volume of each unit in the pegmatite, converting volume to tonnage, determining the tonnage of each mineral (table 11) by use of the data on mineral distribution shown in table 3 , and converting the mineral constituents into chemical equivalents.

Table 12 contains the data on compositions of minerals used in making the calculations. These are based on optical studies, typical chemical analyses recorded in the literature from many localities, and spectrographic analyses of mica.

TABLE 11.-Estimated mineral content of the Peerless pegmatite [Data in this table are not to be interpreted as reserves. Tonnages listed include nonminable as well as minable rock] Mineral Tons

Plagioclase _...

Quartz . .

Muscovite _.

Perthite and microcline $\ldots \ldots \ldots$ 25, 000

Lithia mica. _... 5, 000

Beryl _...

Tourmaline......

Iron-lithium-manganese phosphates_............ 2, 400

Amblygonite-montebrasite...................... 1, 600

Apatite ............ 1, 100

Other minerals................... 1, 500

Total_._. 
TABLE 12.-Composition of minerals used in computing chemical composition of the Peerless pegmatite

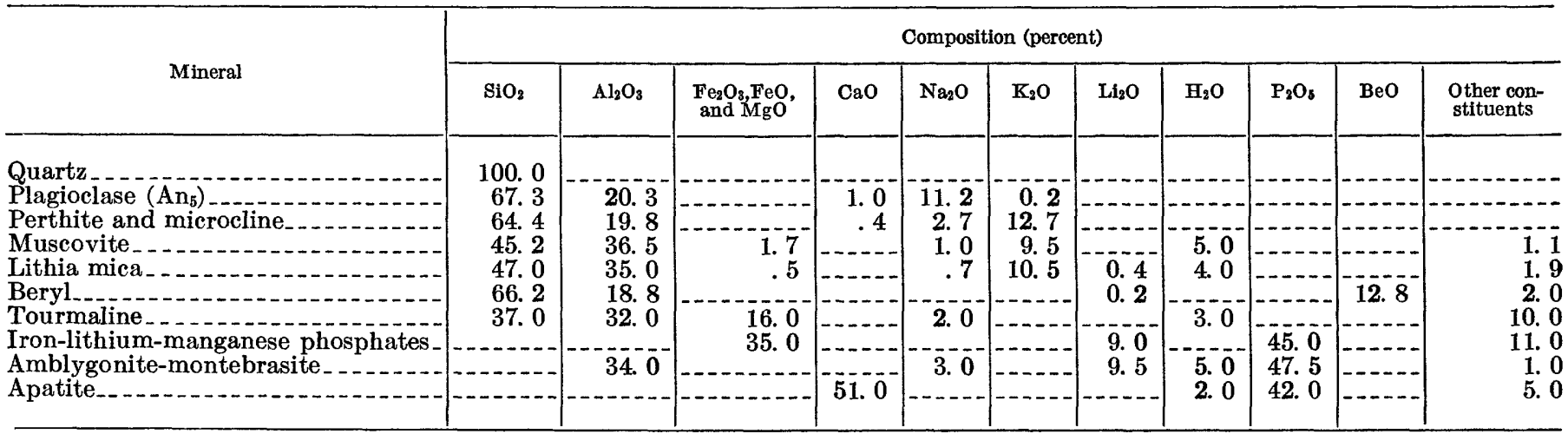

The only calculation of water shown in table 12 , and thus of the completed estimates of the chemical composition of the pegmatite (table 13), is in mica, tourmaline, amblygonite-montebrasite, and apatite. Any additional water that may be contained in the pegmatite cannot be estimated. Other errors that may be introduced by inaccuracies in table 12 probably do not change the final results as much as errors in the tonnage estimates of table 11 .

The calculated chemical composition of the Peerless pegmatite (table 13) shows that the silica content, at 77.0 percent, is extraordinarily high. The only other constituents that form more than 0.6 percent of the pegmatite are alumina, soda, potash, and possibly water. Potash forms only 1.7 percent of the pegmatite, yet soda forms 5.0 percent. Despite the abundance of rare minerals in some units of this pegmatite, the overall content of rare elements is very small.

Similar calculations have also been made to determine the content of silica, alumina, soda, and potash in four arbitrary subdivisions of the pegmatite (table 14). These show that silica increases greatly toward the center of the pegmatite. Alumina decreases as silica increases. Soda is about constant in zones 1 to 5 , but decreases to 0.4 percent in the center of the pegmatite. Potash reaches a maximum of 4.0 percent in zones 3 and 4 , but is much less in outer and inner units.

The mineral distribution of the units (tables 3 to 9 ) indicates that a more detailed breakdown and more complete chemical data would show many additional

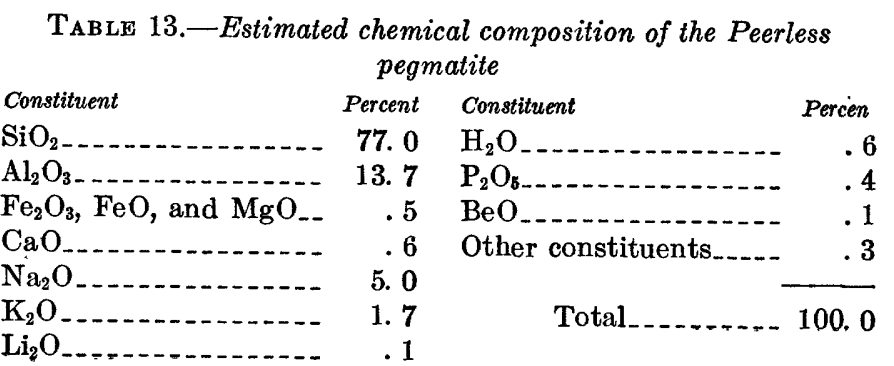

relationships. Silica, for example, is a rich constituent of the border zone (tables 4 and 5). Probably it alternately decreases and increases in the wall zone (table 4, pl. 7). Then it probably increases in zones $3,4,5$, and 6 , and decreases again in zone 7 .

Further discussion of this sort must be delayed until more data are available from this and other pegmatites. The predominance of silica, alumina, soda, and potash, and the very small content of other constituents indicate that laboratory studies on relatively simple systems may be applied directly in studies of petrologic relationships in this pegmatite.

\section{ORIGIN}

The origin of the Peerless and other Black Hills pegmatites has been discussed for many years. The pegmatitic fluid generally has been considered either a derivative or a deep-seated parent magma of the Harney Peak granite. The greatest disagreement concerns the sequence of events after the pegmatitic fluid began to crystallize. The earliest writers considered Black Hills pegmatites to be true igneous rocks. Between 1925 and 1939 different writers emphasized the role of replacement processes in an open system. More recent writers considered systematic fractional crystallization in a restricted system as the chief factor in the formation of the Peerless and other Black Hills pegmatites.

The proximity of the zoned pegmatites like the Peerless to the Harney Peak granite has led most investiga-

TABLE 14.-Distribution of the principal chemical constituents of the Peerless pegmatite

\begin{tabular}{|c|c|c|c|c|c|c|}
\hline \multirow{2}{*}{ Units } & \multirow{2}{*}{ Tons } & \multicolumn{5}{|c|}{ Chemical composition (percent) } \\
\hline & & $\mathrm{SiO}_{2}$ & $\mathrm{Al}_{2} \mathrm{O}_{3}$ & $\mathrm{Na}_{2} \mathrm{O}$ & $\mathrm{K}_{2} \mathrm{O}$ & $\begin{array}{c}\text { Other } \\
\text { constit- } \\
\text { uents }\end{array}$ \\
\hline $\begin{array}{l}\text { Zones: } \\
1 \text { and } 2 \\
3 \text { and } 4 \\
6 \text { and } 7 \text {, and replace- }\end{array}$ & $\begin{array}{l}143,000 \\
130,000 \\
205,000\end{array}$ & $\begin{array}{l}73.7 \\
70.7 \\
79.1\end{array}$ & $\begin{array}{l}16.0 \\
17.6 \\
11.8\end{array}$ & $\begin{array}{l}6.5 \\
4.7 \\
5.3\end{array}$ & $\begin{array}{r}1.3 \\
4.0 \\
.7\end{array}$ & $\begin{array}{l}2.5 \\
3.0 \\
3.1\end{array}$ \\
\hline $\begin{array}{l}\text { ment units } \\
\text { Entire pegmatite. }\end{array}$ & $\begin{array}{r}\mathbf{5 4}, \mathbf{5 0 0} \\
\mathbf{5 3 2}, \mathbf{5 0 0}\end{array}$ & $\begin{array}{r}92.3 \\
77.0\end{array}$ & $\begin{array}{r}4.5 \\
13.7\end{array}$ & .4 .4 & $\begin{array}{l}1.3 \\
1.7\end{array}$ & $\begin{array}{l}1.5 \\
2.6\end{array}$ \\
\hline
\end{tabular}


tors to believe that these rocks are genetically related. Furthermore, the layered pegmatite of the Peerless border and wall zones is similar to the layered pegmatite that is characteristic of the so-called granite of Harney Peak.

The attitude of segments of the Peerless pegmatite and discordance with the schist indicate control of the intrusion by fractures. Dikelike apophyses extending outward from the main body doubtless are also fracture controlled. In some places a secondary schistosity has been formed parallel to the contact. These relations indicate that the pegmatitic fluid was sufficiently viscous to shoulder aside and deform the country rock.

The alteration of staurolite to mica and chlorite in schist near the pegmatite may liave been caused by introduction of water and probably of potash from the pegmatite. Another possibility, however, is that potash was released by biotite in adjacent rock. The Fe: $\mathrm{Mg}$ ratio in the biotite may have increased during the breakdown of staurolite and the formation of chlorite, and as this ratio increases, the potasl content decreases.

Higazy $(1949$, p. 555) has suggested that pegmatites of this area were formed by metasomatic replacement of schist wall rocks. He examined the Peerless pegmatite, but he did no detailed work on it, and did little work on the structural geology of any pegmatite. Instead he based his conclusions on origin almost entirely on the study of thin sections and chemical analyses of perthite, for he erroneously assumed that the pegmatites consist almost solely of perthite, and that a chemical analysis of perthite is equivalent to a chemical analysis of the entire pegmatite. Neither the Peerless nor any other Black Hills pegmatite known to the writers or mentioned in Higazy's paper consists entirely of perthite. Consequently, Higazy's reasoning does not apply to the problem at liand.

The layered structure and repetition of rock types in the border and wall zones indicate a somewhat complex origin for these units that can best be understood by comparing the sequence of layers (table 15) with the normal zonal sequence of Black Hills pegmatites described by Page and others (1953, table 3). The outer layers of the border and wall zones evidently crystallized progressively from assemblages $1 a$ to $3 g$. The only anomaly in this sequence is the second occurrence of assemblage $1 f$. Field relationships show that this is younger than the adjacent layers of assemblage $1 h$, and thus may be a fracture filling injected at a later stage in the formation of the wall zone.

The sudden appearance and equally sudden disappearance of sugary-grained albite-quartz aggregates in two layers of assemblage $2 a$ surrounding a layer of assemblage $3 g$ indicate rapid changes in physical and
TABle 15.-Sequence of layers in border and wall zones, Peerless pegmatite

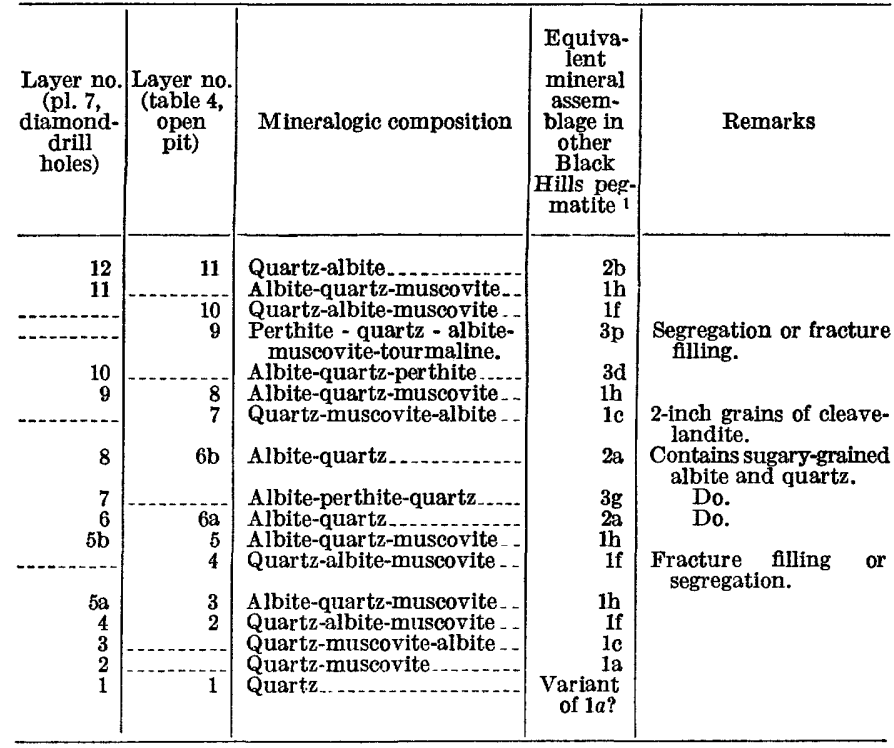

1 Page and others, (1953, table 3).

chemical conditions. Possibly the layer of assemblage $3 g$ formed from liquid that was trapped during rapid crystallization of the sugary- to fine-grained pegmatite of assemblage $2 a$. Perthite-bearing segregations in the wall zone resemble pegmatite that crystallized later as zone 4 of the Peerless, and thus represent similar chemical stages in the crystallization history. Similar pegmatite forms intermediate zones and cores of many other Black Hills pegmatites.

The sugary-grain size of the albite-quartz aggregates may have been caused in part by a sharp decrease in pressure and temperature, resulting in rapid formation of nuclei, and the partial depletion of volatile materials and consequent rapid crystallization. In plate 7 , it can be seen that sugary-grained pegmatite occurs near discordant contacts, where volatile materials or heat are likely to escape; so far as known, however, there is no spatial relationship between sugarygrained pegmatite and altered wall rocks, which would be expected if the volatile material escaped from the fluid into the wall rocks. On the other hand, the alteration of staurolite to mica and chlorite in the wall rock indicates that water was added from the pegmatite. Possibly the volatile materials were depleted during crystallization of mica-bearing pegmatite, and convection in the liquid may not have been rapid enough to replenish the supply. The great decrease in mica content from assemblage $1 a$ to $2 a$ indicates that the volatile content of the fluid decreased during crystallization of these layers.

In table 15 the sugary-grained albite-quartz pegmatite is succeeded by assemblage 1, which in turn is succeeded by assemblage 3 , and similarly by assem- 
blages 1 and 2 . These repetitions may have been caused by several processes.

1. The system may have been open, either because new material was introduced from below, or because volatile materials and heat escaped into the wall rock. These changes would cause changes in chemical equilibrium; and the observed repetition of layers could result.

2. Mixing of liquids from the different segments of the pegmatite may have caused changes in chemical composition at the crystallizing face.

3. Poor convection may have caused the liquid to change in equilibrium at the crystallizing face. Thus layers of assemblages 2 and 3 may have crystallized earlier than they would otherwise. When convection was restored, the minerals of assemblage 1 would again crystallize.

Assemblages 1 and 2 in the innermost part of the wall zone are similar to the outermost zones of many Black Hills pegmatites. The intermediate zones and core similarly are in the sequence described for other pegmatites of the Black Hills (Page and others, 1953, p. 16, table 3). After the wall zone had crystallized, the pegmatitic fluid must have been sealed off from the outside, even if it had not been earlier. Crystallization would then proceed in a restricted system, as described by Page and others (1953, p. 20-23) and by Cameron and others (1949, p. 104-105). As crystals were deposited to form the several zones, the minerals that formed early in the meshwork at the crystallizing front were embayed, corroded, and veined by minerals formed later. Quartz fracture-filling units cut zones that lie outside of the quartz pegmatite of zone $6 a$, and it is logical to assume that these fracture-filling units were formed during the stage when zone $6 a$ was crystallizing.

The core and the two replacement units have a high mica content that indicates concentration of water in the rest-liquid during the last stage of crystallization. It is logical to assume that the replacement bodies were formed from hydrothermal or pneumatolytic materials that escaped into zones that had already crystallized. Relicts of these zones can be recognized in the replacement units.

The genetic significance of replacement textures in the Peerless pegmatite was overemphasized by earlier writers. These writers lacked the detailed maps and drill-hole data now available, and consequently they depended more on detailed mineralogic and textural relations than now seems warranted. F. L. Hess was one of the first to suggest a genetic process involving continuous flow of solutions that replaced preexisting pegmatites, and part of his data was derived from the Peerless pegmatite (Hess, 1925, p. 289-298). Hess described replacement textures among quartz, feldspar, muscovite, and other minerals that are now most logically explained by reaction between crystals and the rest-liquid at the crystallizing front during the formation of the zones.

Landes (1928, p. 519-530, 537-558) made a study of the Peerless and other Keystone pegmatites that led him to suggest a three-stage sequence: a magmatic stage, in which microcline and quartz formed together with some tourmaline, muscovite, beryl, triphylite, and apatite; an intermediate stage, in which hydrothermal solutions soaked through the pegmatite and replaced older minerals with spodumene, amblygonite-montebrasite, and beryl; and a vein stage, in which hydrothermal solutions replaced older minerals and filled fissures with albite, lepidolite, muscovite, tourmaline, quartz, and metallic minerals. Later, Landes (1933, p. 55) noted the possibility that "hydrothermal solutions" in larger pegmatites such as the Peerless, Etta, Hugo, and Ingersoll may have been "residua" of the crystallization of the pegmatite magma. The paragenetic sequence of Landes is based largely on the textural relations of individual minerals, without sufficient evaluation of the significance of the internal structure of the pegmatite. Landes, for example, postulated that the albite was formed during a late "vein stage," because in many places albite forms embayments and veinlike masses that cut other minerals. The more recent mapping of detailed structural relations indicates that albite of the outer zones must have been formed before crystallization of the inner zones. Furthermore, the anorthite content of albite decreases toward the center of the pegmatite, thus indicating normal magmatic differentiation. Significantly, detailed mapping has shown no evidence for through-going channels of hydrothermal solutions.

Ziegler (1914b, p. 275) observed amblygonite along slickensided fault surfaces in the Peerless pegmatite and believed that the amblygonite was deposited after the faulting. Amblygonite-montebrasite found along a fault surface in the locality described by Ziegler has textural relations indicating that it is a normal part of the cleavelandite-quartz assemblage that is cut by the fault, and is not a mineral deposited after faulting.

Weis (1953, p. 681-684) determined the filling temperature of "primary" fluid inclusions in 1 beryl crystal from zone 2, 4 crystals from zone 3 , and 2 crystals from zone 4 . The temperature ranges are so great that it seems unwise, without further work, to attach significance to these results. In the crystal from zone 2 (zone 1 of Weis), 15 inclusions ranged from $257^{\circ}$ to $405^{\circ} \mathrm{C}$, with a mean of $317^{\circ} \mathrm{C} ; 172$ inclusions in 4 crystals from zone 3 (zone 1a of Weis) ranged from $232^{\circ}$ to $450^{\circ} \mathrm{C}$, with a mean of $359^{\circ} \mathrm{C} ; 41$ inclusions in 2 crystals from zone 4 (zone 3 of Weis) ranged from $304^{\circ}$ to $447^{\circ} \mathrm{C}$, with a mean of $405^{\circ} \mathrm{C}$. The determinations are fairly evenly distributed throughout these 
ranges. Weis (1953, p. 692-693) lacked confidence in his data from the Peerless pegmatite. He did suggest, however, that the apparent increase in temperature from the wall inward may be in part explained by evidence obtained by the Geological Survey showing that the Peerless pegmatite "probably formed as a result of two or more separate intrusions." This statement can be explained only as a misunderstanding. The only evidence for multiple intrusion is in the layering of zones 1 and 2, which indicates the possibility that there were injections of new material after crystallization began. Even if this were the correct interpretation, however, it would have little or no bearing on the data obtained by Weis from zones 3 and 4.

Recent laboratory work by Grootemat and Holland $(1955$, p. 1,569$)$ has shown that the potassium-sodium ratio varies systematically in muscovite samples from the wall zone to the core of the Peerless pegmatite. Their data suggested crystallization temperatures of about $500^{\circ} \mathrm{C}$ for the outer zones and about $350^{\circ} \mathrm{C}$ for the core.

Additional work on genesis of this pegmatite should be profitable. Fluid-inclusion studies of minerals from all zones and from different structural positions within each zone might yield significant results.

Mineralogic studies and spectrographic and chemical analyses are needed to determine the nature of the change in composition of the pegmatite magma during crystallization, and of the importance of changing concentrations of the constituents in the crystallization process. The need for further detailed studies of the layering in zones 1 and 2 should be emphasized.

\section{MINERAL DEPOSITS}

Scrap mica is the chief product of the Peerless pegmatite. Other minerals that have been produced are beryl, potash and soda feldspar, amblygonite-montebrasite, and tantalite-columbite (table 1). Minerals of potential economic value that have not yet been marketed include lithia mica, cassiterite, and phosphate minerals of the lithiophilite-triphylite group.

Percentages for all these minerals in the units of the pegmatite are contained in table 3. Beryl grade was determined chiefly by grain measurements on typical faces and on drill cores. No assay data are available from the drill cores. All other grade figures are from visual estimates on many exposures.

\section{MICA}

The main muscovtte mica deposit is zone 3 , cleavelandite-quartz-muscovite pegmatite (first intermediate zone). Mica also occurs in zones $2,4,5$, and 7 , and in the replacement bodies.

The muscovite content of the main mica deposit ranges from 10 to 60 percent, but the average grade is about 28. Books of muscovite in this unit are as much as 3 feet in diameter, and the average is about 5 inches. Because the mica aggregates are coarse grained, about two-thirds of the mica is recoverable by hand cobbing.

Zones 2,4 , and 5 contain 6 to 8 percent mica, and the average grain size ranges from 0.5 inch in zone 2 to 3 inches in zone 5 . Less than one-third of this mica can be recovered by hand cobbing. Ordinarily the only mica recovered from these units is a byproduct during mining for other minerals.

The muscovite is yellowish silvery, and most of the books contain wedge and herringbone structures; some of the books are ruled. High-quality scrap mica is produced everywhere in zone 3 except in areas cut by faults, where there is some iron staining. A few books contain enough flat mica to warrant preparing sheet and punch mica during favorable market conditions (table 2).

The small muscovite-cleavelandite replacement unit contains aggregates of 0.2 -inch muscovite books that can be sold as scrap mica.

\section{IITHIA MICA}

The lithia mica in the core and replacement body of lithia mica-cleavelandite pegmatite may be a potential source of scrap mica for specialized uses. The lithia content of 0.4 percent is much too low for marketing of the lithium, but the content of cesium and rubidium is high.

\section{BERYL}

Beryl occurs chiefly in zone 3 , cleavelandite-quartzmuscovite pegmatite (first intermediate zone). It is extracted from this unit as a byproduct of scrap-mica mining. Beryl has also been obtained from the inner part of the wall zone and from zones 4 and 5 . Traces of beryl have been observed in zones 1 and $6 \mathrm{a}$, and in the muscovite-cleavelandite replacement unit.

The beryl content of the different layers of the wall zone varies widely. Plate 7 shows that the content in layers cut by the drill holes ranges from 0 to 0.6 percent. The richest units contain abundant albite. Measurements of erystals in surface exposures show that the inner part of the wall zone contains much more beryl than the outer part (table 16). The content of the different layers in surface exposures has not been determined.

Grain measurements on surface exposures of the wall zone indicate an average beryl content of 1.08 percent (table 16). Measurements on drill cores give 0.09 percent beryl (table 6). These figures indicate that the content decreases in the keelward parts of the wall zone; this decrease may be correlated with a corresponding decrease in the albite content. Possibly, however, the 
TABLe 16.-Measurements of beryl in seven exposures of zone 2 , albite-quartz-muscovite pegmatite (wall zone), Peerless pegmatite

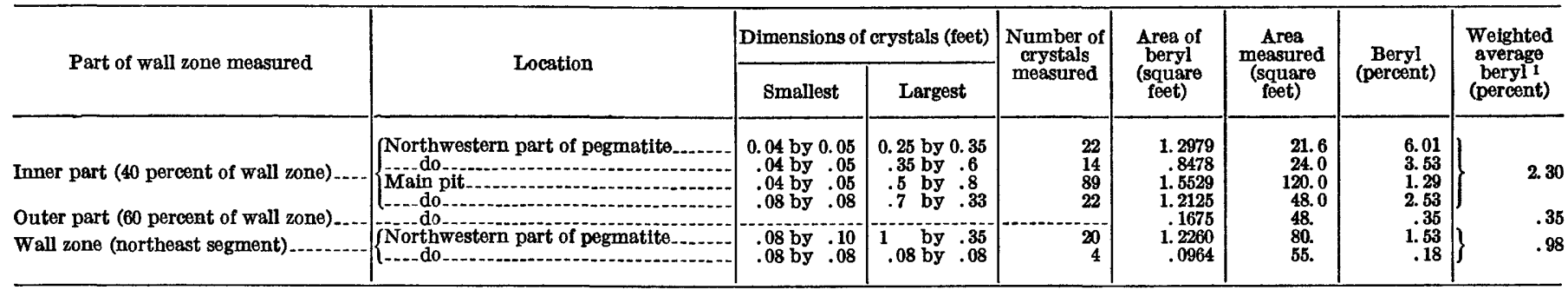

1 Average percent beryl in wall zone, 1.08 .

explanation of the low-beryl content of the drill cores is that the euhedral beryl of the wall zone breaks away from the core and mixes with the sludge during drilling. This possibility cannot be evaluated without assays of both core and sludge. In the absence of such data, the grade is best estimated as 0.6 percent beryl-an average of the surface and drill-hole figures. The inner part of the wall zone probably has nearly the same grade as the 1.7 percent beryl content of zone 3 .

Beryl also is irregularly distributed in zone 3 ; the beryl content of mica-rich parts of the zone generally is less than 1 percent, whereas parts of the zone rich in cleavelandite contain as much as 15 percent. Measurements on typical surface exposures indicate an average grade of 1.46 percent (table 17). The average grade in the drill holes is 1.93 percent (table 7). Consequently the average grade throughout the zone is about 1.7 percent beryl.

Data on the beryl content of other zones are less accurate and are determined chiefly on visual estimates. Zone 4 probably has less than 0.5 percent. Zone 5 has about 0.5 percent in surface exposures, but measurements in the drill cores indicate a content of 0.12 percent.

The mineralogic properties of beryl in the different units are presented in table 18. The color ranges from colorless to white and from pale yellowish white to greenish white. Subhedral to euhedral crystals are most common, but shell intergrowths of beryl and cleavelandite were noted in zone 3 , and anhedral masses of beryl intergrown with cleavelandite, quartz, and muscovite are common in zones 3 and 5 . Crystals in the border zone and the outer part of the wall zone are too small to be hand-cobbed. The crystals in the inner part of the wall zone and in the first intermediate zone average 3 inches in diameter. Masses of beryl as much as 30 inches in diameter were produced from zone 4 . The proportion of the total beryl that can be handcobbed is about one-third in zone 2 , two-thirds in zone 3 , and one-half in zone 5 .

The $\mathrm{BeO}$ content of the beryl ranges from an average of 12.4 percent in zone 4 to an average of 13.1 percent in zone 1. A few crystals are as low as 12.3 percent $\left(\mathrm{N}_{\omega}=1.587\right)$ or as high as 13.5 percent $\mathrm{BeO}\left(\mathrm{N}_{\omega}=1.574\right)$.

Beryl in the layered rocks of the border and wall zones has a range in the index of refraction and $\mathrm{BeO}$ content that is almost as great as the range in all the units of the pegmatite. The data for these units have been tabulated in plate 7 . The data show that the $\mathrm{BeO}$ content of beryl decreases from the wall inward in the border and wall zones, but in contrast the $\mathrm{BeO}$ content in the layers containing sugary-grained albitequartz aggregates generally is higher than in the adjacent lower albite-quartz-muscovite unit.

\section{POTASH FELDSPAR}

The chief potash feldspar of the Peerless pegmatite is perthite in zone 4 , perthite-cleavelandite-quartz pegmatite (second intermediate zone). Perthite also is abundant in some layers of the wall zone (table 4 and pl. 7) that resemble zone 4 in composition. Nonperthitic microcline is a significant constituent of zone 6a, quartz-microcline pegmatite. The average grade of the second intermediate zone is about 40 percent

TABLE 17.-Measurements of beryl in five exposures of zone 3 , cleavelandite-quartz-muscovite pegmatite (first intermediate zone), Peerless pegmatite

\begin{tabular}{|c|c|c|c|c|c|c|c|}
\hline \multirow{2}{*}{ Location } & \multicolumn{2}{|c|}{$\begin{array}{c}\text { Dimensions of crystals } \\
\text { (feet) }\end{array}$} & \multirow{2}{*}{$\begin{array}{l}\text { Number } \\
\text { of beryl } \\
\text { crystals }\end{array}$} & \multirow{2}{*}{$\begin{array}{c}\text { Ares } \\
\text { of beryl } \\
\text { (square feet) }\end{array}$} & \multirow{2}{*}{$\begin{array}{c}\text { Area } \\
\text { (squarured feet) }\end{array}$} & \multirow{2}{*}{$\underset{\text { (percent) }}{\text { Beryl }}$} & \multirow{2}{*}{$\begin{array}{l}\text { Weighted } \\
\text { average } \\
\text { beryl } \\
\text { (percent) }\end{array}$} \\
\hline & Smallest & Largest & & & & & \\
\hline $\begin{array}{l}\text { Main pit. } \\
\text { Do } \\
\text { Do } \\
\text { Northwestern part of pegmatite } \\
\text { Do }\end{array}$ & $\begin{array}{l}0.03 \text { by } 0.04 \\
.05 \text { by } .15 \\
.1 \text { by } .2 \\
.02 \text { by } .02 \\
.05 \text { by } .05\end{array}$ & $\begin{array}{l}0.6 \text { by } 1.5 \\
.6 \text { by } .8 \\
.35 \text { by } 1.2 \\
.07 \text { by } 1.2 \\
.30 \text { by } .45\end{array}$ & $\begin{array}{l}12 \\
14 \\
11 \\
36 \\
13\end{array}$ & $\begin{array}{r}2.0332 \\
2.6675 \\
1.8210 \\
.8755 \\
.3956\end{array}$ & $\begin{array}{r}100.0 \\
315.0 \\
42.0 \\
39.6 \\
38.2\end{array}$ & $\begin{array}{l}2.03 \\
.85 \\
4.34 \\
2.21 \\
1.04\end{array}$ & 1.46 \\
\hline Total & & - & 86 & 7.7928 & 534.8 & - & \\
\hline
\end{tabular}


Table 18.-Mineralogy of beryl, Peerless pegmatite

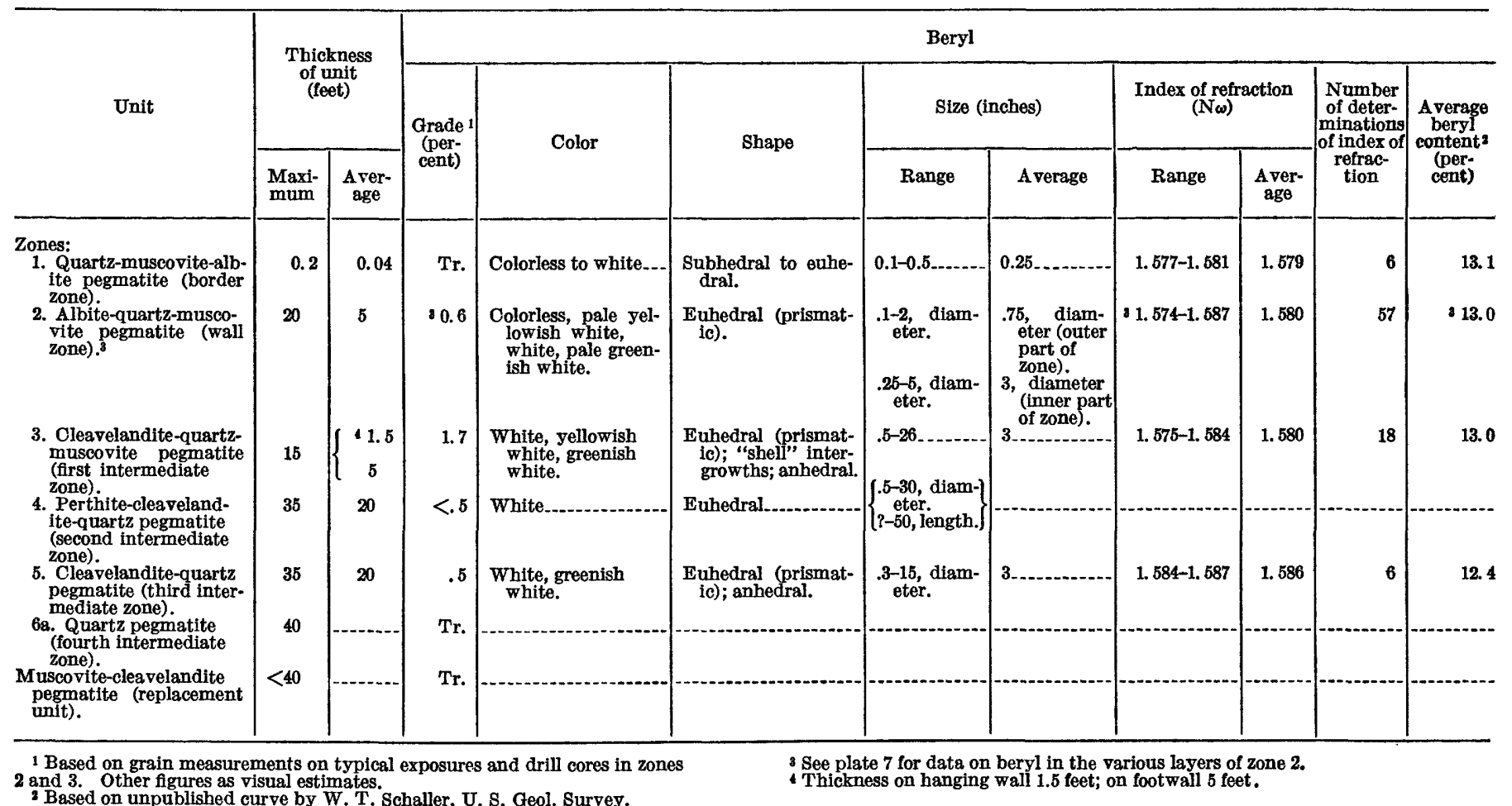

perthite, but the perthite content ranges from 65 percent in the upper and outer parts of the zone to about 20 percent in the inner part. The perthite occurs in blocky crystals ranging from 1 inch to 20 feet in maximum dimension; the average length is about 2 feet. The perthite is clean and nearly free from iron stain except in areas cut by faults.

Nonperthitic microcline crystals that average about 10 feet in diameter form about 40 percent of zone $6 \mathrm{a}$ (quartz-microcline pegmatite). This unit has not been mined for feldspar because it is small and contains large masses of quartz that would be difficult and expensive to mine.

\section{SODA FELDSPAR}

The large cleavelandite aggregates of the Peerless pegmatite have been mined for soda feldspar, especially in zones 3, 4, and 5. Cleavelandite and nonplaty albite are so abundant in the Peerless pegmatite (table 3 ) that mining depends less on grade than on market conditions and on the feasibility of recovering cleavelandite as a byproduct of mining for other minerals.

The average grade of zones, 3,4 , and 5 is about 40 percent cleavelandite. Aggregates of cleavelandite average 4 inches in diameter, but some are as large as 5 feet.

\section{AMBLYGONITE-MONTEBRASITE}

Amblygonite-montebrasite occurs chiefly in the cleavelandite-quartz pegmatite of zone 5 (table 3 ), but also occurs in some of the layers of the wall zone. Traces of it are found in zone 3.

The average grade of zone 5 is between 0.5 and 1 percent amblygonite-montebrasite. The mined-out upper parts of this unit near the main pit may have contained more than 1 percent. Hess (1925, p. 289) described a mass in the Peerless pegmatite as being "27 feet across," with other dimensions almost as large. Such a mass, however, would have contained nearly as much amblygonite-montebrasite as the total recorded production from the Peerless mine. Nevertheless, present exposures in old workings in the upper part of the pegmatite contain about 1 percent amblygonitemontebrasite. The grade is much less in underground exposures.

The amblygonite-montebrasite of zone 5 occurs in rounded, grayish-white crystals that range in diameter from 0.2 inch to 3 feet; the average size is about 6 inches. The average size in the wall zone is about 0.75 inch, and in the first intermediate zone it is about 1 inch. The grains are commonly corroded and rounded by other minerals of the zones and are coated with a white dusty alteration product. Optical properties given in tables 6,7 , and 9 indicate that the amblygonite- 
montebrasite is nearer the montebrasite (hydroxyl) end than the amblygonite (fluorine) end of the series (based on Winchell, 1951, p. 223).

\section{OTHER MINERALS}

The Peerless pegmatite also contains tantalitecolumbite, cassiterite, and lithiophilite-triphylite.

Tantalite-columbite has been observed in zones $1,2,3,5$, and 7 , and in the replacement units. The average grade probably does not exceed 1 pound of tantalite-columbite in 10 tons of rock in any of these units, and the grade of zones 1 and 2 may be much less.

Tantalite-columbite occurs as thin plates that average 0.2 inch in length and 0.01 inch in thickness. Blades as much as 4 inches in length and 0.15 inch in thickness are intergrown with cleavelandite and muscovite in zones 3 and 5 and in the muscovite-cleavelandite replacement unit. The intimate association with muscovite and cleavelandite in these units makes hand-cobbing difficult. However, Hess (1925, p. 293) reported that a single crystal of "columbite," associated with quartz and mica, weighed more than 200 pounds.

Cassiterite has been observed in zones $2,3,5$, and 7 , and in the replacement units. The richest of these units is zone 3 , which probably contains an average of 0.2 pound of tin per ton of rock; a very rich exposure covering 315 square feet in the main pit contains about 5 pounds of tin per ton of rock. Zones 5 and 7 and the replacement units may contain 0.1 pound per ton. The wall zone contains only a trace.

The size of observed grains of cassiterite ranges from less than 0.1 to 2 inches, but larger masses have been reported by A. F. Walker, the resident mine superintendent. The cassiterite is erratically distributed, but it is commonly associated with muscovite.

About 40 tons of dark-colored aggregates of phosphate minerals has been stockpiled east of the main pit, but none of this material has been sold. The minerals in these aggregates are probably chiefly members of the lithiophilite-triphylite group and their alteration products. These phosphate minerals occur as irregular aggregates and pod-shaped masses in zones $2,3,5,6$, and 7 , and in the lithia mica-cleavelandite pegmatite replacement unit. Individual masses of phosphate minerals range in size from less than 0.5 to 12 inches. Irregular aggregates of the phosphate minerals intergrown with varying amounts of other minerals are commonly 3 feet in diameter in zone 5 . They form about 1 percent of zones 5 and 7 but less than 1 percent of the other units.

\section{|RESERVES}

The reserves of mica, beryl, potash feldspar, and amblygonite-montebrasite are estimated at 1 to 6 times past production of the minerals; reserves of soda feldspar are many times greater.

The chief minable structural unit is zone 3, cleavelandite-quartz-muscovite pegmatite (first intermediate zone). This zone contains the principal reserves of muscovite and beryl. The average thickness of zone 3 is about 5 feet in the footwall and about 1.5 feet in the hanging wall (pl. 6). The depth ranges from 32 feet (pl. 6, section $F-F^{\prime}$ ) to 215 feet (pl. 6, section $\left.A-A^{\prime}\right)$, as measured downdip. The total length at the surface is about 360 feet.

Adjacent parts of the wall zone also contain beryl and muscovite, as well as small quantities of potash feldspar. The average thickness of the wall zone is about 5 feet, but the maximum is 20 feet. Beryl occurs chiefly in the inner 40 percent of the zone.

The main potash feldspar deposit is zone 4 . This zone is crescent shaped in cross section (pl. 6), and occurs mainly along the crest of the pegmatite and along the hanging walls of northeastward-dipping limbs. The deposits is as much as 35 feet thick in the upper part of the pegmatite (pl. 6, section $D-D^{\prime}$ ), but it pinches out downdip. A large outcrop of the second intermediate zone in the northeastern part is 235 feet long and 95 feet in maximum width (pl. 4); two smaller outcrops in the northwestern part are 12 and 25 feet in length.

Potash feldspar reserves also are present in zone 6a, quartz-microcline pegmatite. This zone is in the unmined pinnacle in the main pit (pl. 4), where it is 80 feet long and 25 feet in maximum width; a smaller outcrop to the north of the unmined pinnacle is 8 feet in diameter. The maximum thickness is probably about 40 feet.

Zone 5, cleavelandite-quartz pegmatite, is noted chiefly for its amblygonite reserves, but it is also rich in soda feldspar. Most of this deposit is between 15 and 30 feet thick; the depth measured downdip ranges from 22 feet (pl. 6, section $F-F^{\prime}$ ) to 250 feet (pl. 6, section $A-A^{\prime}$ ). The length at the surface is 375 feet.

Zone 7 and the replacement bodies are small. The largest continuous exposure of the lithia mica-bearing core and replacement unit is 48 feet long. The thickness may be as much as 50 feet. Smaller exposure of these rocks occur in the northern part of the main pit (pl. 4). The muscovite-cleavelandite replacement unit crops out in two exposures, 4 by 7 and 30 by 60 feet, in the old cut northwest of the unmined pinnacle (pl. 4).

\section{LITERATURE CITED}

Cameron, E. N., Jahns, R. H., McNair, A. H., and Page, L. R., 1949, Internal structure of granitic pegmatites: Econ. Geology Mon. 2.

Grootemat, T. B., and Holland, H. D., 1955, Sodium and potassium content of muscovites from the Peerless pegmatite, 
Black Hills, South Dakota (abs.): Geol. Soc. America Bull., v. 66, p. 1,569.

Grout, F. F., 1932, Petrography and petrology: 522 p., New York, MeGraw-Hill Book Co., Inc.

Headden, W. P., 1893, Stannite and some of its alteration products from the Black Hills, South Dakota: Am. Jour. Sci., 3d ser., v. 45, p. 105-110.

Hess, F. L., 1925, The natural history of the pegmatites: Eng. and Min. Jour., v. 120, p. 289-298.

Higazy, R. A., 1949, Petrogenesis of perthite pegmatites in the Black Hills, South Dakota: Jour. Geology, v. 57, p. 555581.

Landes, K. K., 1928, Sequence of mineralization in the Keystone, South Dakota, pegmatites: Am. Mineralogist, v. 13, p. 519-530, 537-558.

-1933, Origin and classification of pegmatites: Am. Mineralogist, v. 18 , p. 33-56, 95-103.

Levinson, A. A., 1953, Studies in the mica group; relationship between polymorphism and composition in the muscovitelepidolite series: Am. Mineralogist, v. 38, p. 88-107.

Page, L. R., and others, 1953, Pegmatite investigations, 1942-45, Black Hills, South Dakota: U. S. Geol. Survey Prof. Paper 247.

Runke, S. M., Mullen, D. H., and Cunningham, J. B., 1952, Progress report on pegmatite investigations in South Dakota for fiscal year ended June 30, 1951: U. S. Bur. Mines Rept. Inv. 4928.

Schwartz, G. M., 1928, The Black Hills mineral region: Am. Mineralogist, v. 13 , p. 56-63.

Sheridan, D. M., Stephens, H. G., Staatz, M. H., and Norton, J. J., 1955, Geology of the Peerless pegmatite, Black Hills, South Dakota (abs.): Geol. Soc. America Bull., v. 66, p. 1,616 .

Smith, M. C., 1950, Forty-seventh annual report of the inspector of mines for the year 1949, South Dakota: Inspector of Mines, South Dakota.

Stephens, H. G., and Staatz, M. H., 1948, Mineralogy and structure of the Peerless pegmatite, Keystone, Pennington County, S. Dak. (abs.): Geol. Soc. America Bull., v. 59, p. 1,400 .
United States Bureau of Mines, 1953, Materials survey; beryllium: Rept. compiled for National Security Resources Board by U. S. Bur. Mines with cooperation of the U. S. Geol. Survey, table IV-1.

Weis, P. L., 1953, Fluid inclusions in minerals from zoned pegmatites of the Black Hills, South Dakota: Am. Mineralogist, v. 38, p. 671-697.

Winchell, A. N., 1951, Elements of optical mineralogy: Pt. 2, Descriptions of minerals, 4th ed., New York, John Wiley \& Sons, Inc.

Ziegler, Victor, 1914a, The minerals of the Black Hills: S. Dak. School of Mines Bull. 10.

1914b, The differentiation of a granite magma as shown by the paragenesis of the minerals of the Harney Peak region, South Dakota: Econ. Geology, v. 9, p. 264-277.

\section{LOGS OF U. S. BUREAU OF MINES DIAMOND-DRILL HOLES}

Much of the data for this report was obtained from the study of cores from seven diamond-drill holes made by the U. S. Bureau of Mines in the fall of 1949. The purpose of the drilling was to determine the extent of beryl-bearing units at depth in the Peerless pegmatite. The drilling was under the supervision of Stuart Ferguson and Eugene O. Binyon of the U. S. Bureau of Mines. Geologic work during the drilling was done by D. M. Sheridan, R. E. Roadifer, and J. J. Norton of the U. S. Geological Survey. Sheridan logged the drill cores.

Throughout the logs, modal figures for all minerals except beryl are visual estimates. The errors in these estimates are not known. Beryl content was determined by using a planimeter to measure the area of tracings of beryl crystals exposed on the surface of the cores.

Logs of U.S. Bureau of Mines diamond-drill holes, Peerless pegmatite, Pennington County, S. Dak.

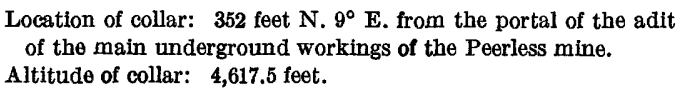

Location of collar: 352 feet N. $9^{\circ}$ E. from the portal of the adit of the main underground workings of the Peerless mine. Altitude of collar: $4,617.5$ feet.

Hole 1

Inclination: Minus $39^{\circ}$. Bearing: S. $631 / 2^{\circ} \mathrm{W}$. Length: 210.0 feet.
Feet

$0-10.0$

$10.0-63.0$
Overburden. No core.

Quartz-mica-chlorite schist: Interbedded with quartz-mica schist. Irregular discontinuous quartz stringers, as much as 6 inches thick, constitute about 5 percent of the core. Some of the quartz stringers contain muscovite $(<10$ percent) and traces of green apatite in grains as much as 0.1 inch in diameter.

Quartz-mica-chlorite schist beds cut at 10-40.7 feet and at 45.9-60.8 feet consist of: quartz (45 percent), muscovite ( 30 percent), biotite $(20$ percent), ehlorite $(4$ percent), garnet $(<1$ percent), and staurolite $(<1$ percent). Pseudomorphs of muscovite, biotite, and chlorite after euhedral staurolite, 0.05 to 1 inch in diameter, constitute as much as 5 percent of this schist. Some pseudomorphs contain relicts of brown staurolite. Metacrysts of staurolite form about 2 percent of the core from 10-14.7 feet but the pseudomorphism to micaceous minerals increases toward the pegmatite contact.

Quartz-mica schists beds cut at 40.7-45.9 feet and 60.8-63.0 feet consist of: quartz (50 percent), muscovite (30 percent), biotite $(20$ percent), and garnet (trace). The schist for 3 inches above the pegmatite contact at 63.0 feet has been altered to a muscovite-rich schist containing muscovite (50 percent), quartz (45 percent), and biotite (5 percent). 
Feet
$63.0-101.0$
$63.0-63.2$

$63.2-73.4$

73.4-76.2

$76.2-84.6$

84.6-87.4

87.4-100.7

$100.7-101.0$

$101.0-210.0$

\author{
Hole 1-Continued \\ Description
}

Pegmatite.

Quartz-muscovite ${ }^{1}$ pegmatite (zone 1, border zone): Very fine grained ( 0.1 inch). Contains quartz (60 percent), muscovite ( 35 percent), albite(?) ( 3 percent), apatite ( $<1$ percent), and tourmaline $(<1$ percent).

Quartz-albite-muscovite pegmatite (zone 2, wall zone): Contains quartz (55 percent), albite (30 percent), muscovite $(12$ percent), tourmaline ( $<1$ percent), apatite $(<1$ percent), perthite $(<1$ percent), unidentified alteration products of phosphate minerals ( $<1$ percent), garnet (trace), tantalite-columbite (trace), cassiterite? (trace), beryl (trace), and loellingite(?) (trace). Average grain size is about 0.35 inch, but the size varies widely. Albite is white to grayish-white; the minimum index of refraction $\left(\mathrm{N}_{\alpha}^{\prime}\right)$ ranges from 1.530 at 63.3 feet to 1.528 at 72 feet. Muscovite is yellowish silvery; the maximum size of books is 2 inches. Two pale-white translucent grains of beryl, 0.5 by 0.35 inch and 0.25 by $0.35 \mathrm{inch}$, occur at 63.9 feet; the index of refraction $\left(\mathrm{N}_{\omega}\right)$ is 1.581. Black tourmaline at 66.4 feet has $\mathrm{N}_{\omega}=1.67$. One grain of perthite, 1.7 by 1 inch, at 71.5 feet is veined and embayed by quartz.

Quartz-cleavelandite-muscovite pegmatite (zone 3, first intermediate zone): Contains quartz (44 percent), cleavelandite ( 35 percent), muscovite $(20$ percent), tourmaline ( $<1$ percent), and apatite ( $<1$ percent). Average grain size is about 1.5 inches. Cleavelandite is white to grayish white; minimum index of refraction $\left(\mathrm{N}_{\alpha}{ }^{\prime}\right)$ is 1.528. Maximum size of yellowish-silvery muscovite books is 3 inches. The index of refraction $\left(\mathrm{N}_{\omega}\right)$ of a bluish-black grain of tourmaline at 75.0 feet is 1.66. Cleavelandite-quartz-muscovite pegmatite (zone 5, third intermediate zone): Contains cleavelandite (52 percent), quartz (40 percent), muscovite ( 6 percent), tourmaline ( $<1$ percent), and apatite ( $<1$ percent). Average grain size is about 1.5 inches. Cleavelandite $\left(\mathrm{N}_{\alpha}^{\prime}=1.528\right)$ constitutes 97 percent of the core from $\mathbf{7 6 . 2}$ to $\mathbf{7 8 . 4}$ feet, but is distributed evenly in the rest of the unit in aggregates that range in size from 0.5 to 4 inches. Yellowish-silvery muscovite books are as long as 2.25 inches.

Quartz-cleavelandite-muscovite pegmatite (zone 3, first intermediate zone): Contains quartz (64 percent), cleavelandite ( 25 percent), muscovite (10 percent), tourmaline $(<1$ percent), apatite (trace), and tantalite-columbite (trace). Average grain size is about 2 inches. Cleavelandite and muscovite are the same as between 73.4 and 76.2 feet. Two plates of tantalite-columbite are 0.2 by 0.01 inch.

Albite-quartz-perthite pegmatite (zone 2, wall zone): Contains albite (45 percent), quartz (35 percent), perthite (10 percent), muscovite $(6$ percent), tourmaline ( 1 percent), unidentified alteration products of phosphate minerals $(<1$ percent), apatite $(<1$ percent), tantalite-columbite (trace), and garnet (trace). The zone can be subdivided into layers on the basis of mineralogy (see table at end of $\log$ ).

Average grain size is $0.5 \mathrm{inch}$, but it decreases to 0.3 inch near the contact with the border zone at 100.7 feet. Perthite crystals, however, are as much as 4.5 inches. Perthite is pale flesh colored; it is embayed and veined by albite, quartz, and muscovite. Albite occurs chiefly as blocky to subplaty grains having an average size of 0.3 inch. The minimum index of refraction of cleavage fragments $\left(\mathrm{N}_{\alpha}^{\prime}\right)$ is 1.528-1.529. Albite also occurs as very fine grained $(<0.05$ inch) irregular aggregates that are about 1 inch thick $\left(\mathrm{N}_{\alpha}^{\prime}=1.528-1.529\right)$. Muscovite has an average grain size of 0.15 inch near the contact at 100.7 feet, but books are as large as 2 inches at 87.4 to 92.1 feet. Bluishblack grains of tourmaline $\left(\mathrm{N}_{\omega}=1.66\right)$ average 0.15 inch, but aggregates are as large as 1 inch.

Quartz-muscovite pegmatite (zone 1, border zone): Very fine grained (0.1 inch). Contains quartz (61 percent), muscovite ( 35 percent), albite ( 3 percent), apatite (trace), and tourmaline? (trace). White grains of albite, 0.15 inch, occur only at 100.7-100.75 feet.

Quartz-mica schist: Interbedded with quartz-mica-chlorite schist. Irregular discontinuous quartz stringers, 0.1 to 1.5 inches thick, constitute about 5 percent of the core. A quartz stringer, 1.5 inches thick, at 197.9 feet contains traces of pyrite.

The quartz-mica schist contains quartz (49 percent), muscovite ( 30 percent), biotite (20 percent), chlorite (0-0.3 percent), and garnet ( $<1$ percent). Some beds contain as much as 5 percent pseudomorphs of muscovite and biotite after euhedral staurolite, but the pseudomorphs generally are less common than in quartz-mica-chlorite schist.

The quartz-mica-chlorite schist contains quartz (44 percent), muscovite (35 percent), biotite (10-15 percent), chlorite (5-10 percent), and garnet ( 1 percent). Pseudomorphs of muscovite, biotite, and chlorite after euhedral staurolite form about 5 percent of this schist. Quartz-mica-chlorite schist was cut at 130.7-143, 148-162.4, 162.9-164.4, 165.7-169.5, 170.5-175.2, and 175.9-178 feet. At 180.7-185.7 feet and 190.7-197.3 feet, quartz-mica schist and quartz-mica-chlorite schist are finely interbedded in 1-inch beds.

1 Throughout the logs, the sequence of mineral names applies only to the core segment that is being described. It may differ from the name of the entire unit. Zone 1 , for example, is predominantly quartz-plagioclase pegmatite, even though it is quartz-muscovite pegmatite in this core segment. 


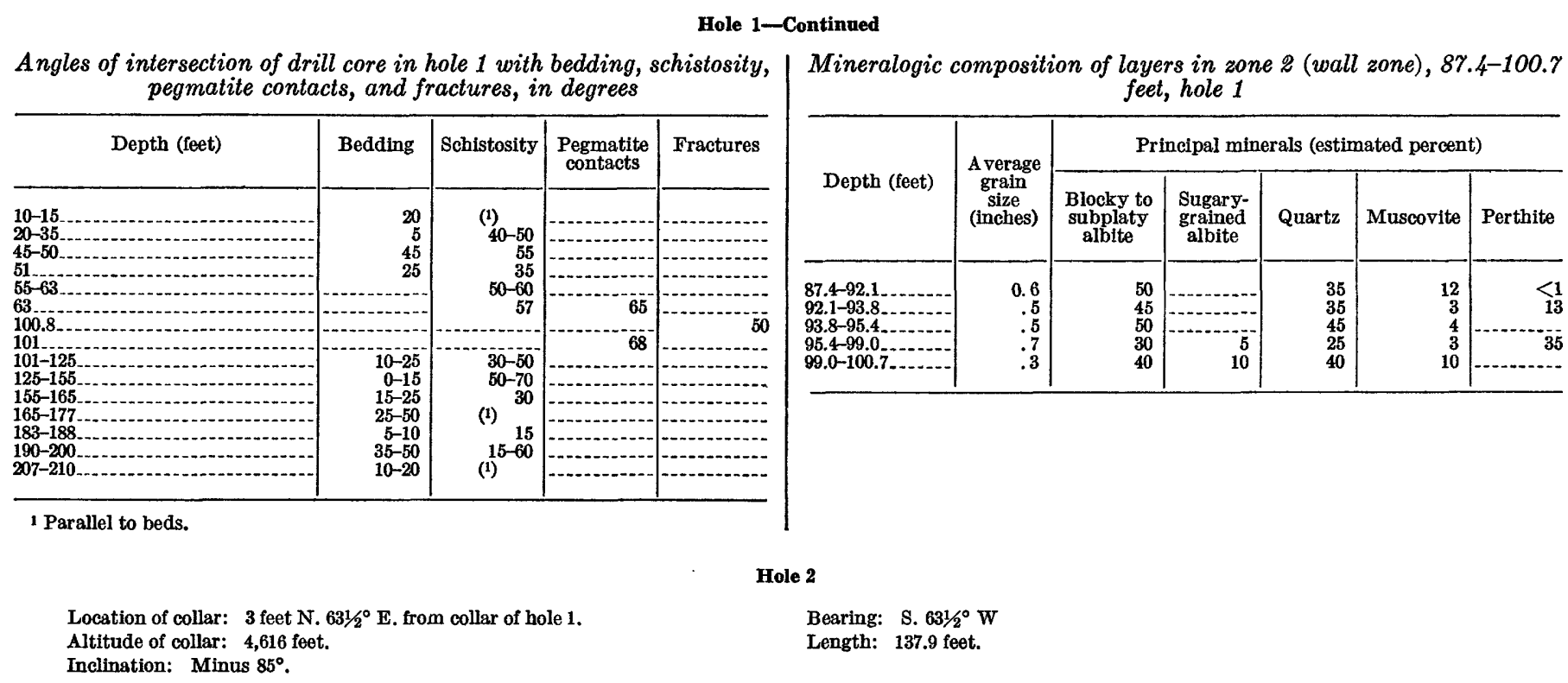

$0-16.0^{\text {Feet }}$

$16.0-31.0$

$31.0-66.0$

$66.0-66.5$

$66.5-92.0$

$66.50-66.52$

$66.52-70.8$

$70.8-72.1$

$72.1-82.9$
Overburden and schist. No core.

Description

Quartz-mica-staurolite schist: Contains quartz (50 percent), muscovite (30 percent), biotite (14 percent), staurolite ( 5 percent), garnet $(<1$ percent), and chlorite $(<1$ percent). Brown metacrysts of staurolite range in size from 0.15 to 0.75 inch. Pseudomorphs of muscovite and biotite after staurolite occur from 26 to 31 feet. Irregular discontinuous quartz stringers, 0.1 to 3.5 inches thick, constitute about 10 percent of the core.

Quartz-mica-chlorite schist: Contains quartz (45 percent), muscovite (30 percent), biotite (17 percent), chlorite $(6$ percent), garnet ( 1 percent), staurolite $(<1$ percent), and tourmaline? (trace). Staurolite metacrysts form about 2 percent of the core from 31 to $\mathbf{4 6}$ feet, but pseudomorphism to muscovite, biotite, and chlorite increases as the pegmatite contact is approached. From 46 to 66 feet, staurolite occurs only as relicts in pseudomorphs that range in size from 0.1 to 1.5 inches. Traces of black tourmaline?, in grains less than 0.05 inch, occur at 63-66 feet. Irregular discontinuous quartz stringers 0.1 to 3 inches thick form about 5 percent of the core.

Quartz-muscovite schist: An altered variety of schist lying adjacent to the pegmatite contact. Contains quartz ( 54 percent), muscovite ( 45 percent), and tourmaline? ( $<1$ percent). Black grains of tourmaline are less than 0.05 inch. Irregular discontinuous stringers of quartz, $0.05-0.1$ inch thick, form about 15 percent of the core. The core is heavily iron stained.

Pegmatite.

Quartz-muscovite pegmatite (zone 1, border zone): Very fine grained ( 0.05 inch) pegmatite containing quartz (64 percent), muscovite ( 35 percent), tourmaline $(<1$ percent), and apatite $(<1$ percent). The index of refraction $\left(\mathrm{N}_{\omega}\right)$ of bluish-black tourmaline is 1.67.

Quartz-albite-muscovite pegmatite (zone 2, wall zone): Contains quartz (50 percent), albite (35 percent), muscovite (13 percent), tourmaline ( 1 percent), apatite $(<1$ percent), tantalite-columbite $(<1$ percent), garnet $(<1$ percent), and an unknown yellowish-gray mineral that may be lithia mica (trace). The average grain size is about 0.5 inch, but muscovite books are as much as 1.75 inches. This zone can be subdivided into layers on the basis of mineralogy (see table at end of $\log$ ).

Albite is grayish white. The minimum index of refraction of cleavage fragments $\left(\mathrm{N}_{\alpha}{ }^{\prime}\right)$ is 1.528 . Tourmaline occurs as black euhedral grains $\left(\mathrm{N}_{\omega}=1.67\right)$.

Quartz-cleavelandite-muscovite pegmatite (zone 3, first intermediate zone): Contains quartz (53 percent), cleavelandite ( 25 percent), muscovite $(20$ percent), apatite $(<1$ percent), tourmaline ( $<1$ percent), and tantalite-columbite $(<1$ percent). Average grain size is about 1 inch. The maximum size of recovered books of muscovite is 4 inches. Three plates of tantalite-columbite are 0.08 by 0.01 inch.

Cleavelandite-quartz pegmatite (zone 5, third intermediate zone): Contains cleavelandite (82 percent), quartz (14 percent), muscovite (3 percent), apatite $(<1$ percent), and tourmaline (trace). The average grain size is about 1 inch. The outer part of the zone, at 72.1-73.0 feet, is relatively rich in quartz (65 percent), and has correspondingly less cleavelandite (30 percent). Cleavelandite forms 75 percent of the core at 73.0-77.0 feet, and 96 percent at 77.0-82.9 feet. The minimum index of refraction of cleavage fragments $\left(\mathrm{N}_{\alpha}{ }^{\prime}\right)$ of the cleavelandite is 1.528. The maximum size of muscovite books is 1.75 inches.

Quartz pegmatite (zone 6b, fourth intermediate zone): Consists entirely of massive quartz. 
Feet

87.6-90.3

$90.3-91.95$

$91.95-92.0$

$92.0-100.8$

$100.8-127.6$

$100.8-110.3$

110.3-111.4

$111.4-119.3$

119.3-127.6

\author{
Fole 2-Continued \\ Description
}

Pegmatite-Conti nued

Cleavelandite pegmatite (zone 5, third intermediate zone): Contains cleavelandite (93 percent), quartz (3 percent), muscovite (3 percent), apatite (trace), and tantalite-columbite (trace). The average size of individual grains is about 1 inch.

Cleavelandite-quartz-muscovite pegmatite (zone 3, first intermediate zone): Contains cleavelandite (72 percent), quartz (16 percent), muscovite (11 percent), and apatite ( $<1$ percent). Average grain size is about 1 inch. The maximum size of recovered muscovite books is about 3 inches. The minimum index of refraction $\left(\mathrm{N}_{\alpha}{ }^{\prime}\right)$ of cleavelandite is 1.528 .

Quartz-muscovite-albite pegmatite (zone 1, border zone): Contains quartz (55 percent), muscovite (25 percent), and albite (20 percent). Average grain size is very fine $(0.02 \mathrm{inch})$. The maximum size of muscovite books is 0.25 inch. White to creamy-white albite $\left(\mathrm{N}_{\alpha}{ }^{\prime}=1.529\right)$, in 0.2 -inch grains, occurs only at 91.95 feet.

Quartz-muscovite-tourmaline schist: Contains quartz (40 percent), muscovite (35 percent), tourmaline (25 percent), and apatite (trace). Black euhedral grains of tourmaline $\left(\mathrm{N}_{\omega}=1.67\right)$ range in size from less than 0.05 to 1.1 inches, but the average tourmaline grain is 0.5 inch long and 0.2 inch in diameter. The tourmaline crystals contain megascopically visible quartz grains, which are oriented in layers parallel to the adjacent bedding. The tourmaline grains lie in the plane of the foliation but are diversely oriented in this plane. Traces of bluish-green apatite in 0.5-inch grains occur at 92.0-92.2 feet. The composition of the schist is fairly uniform except for a quartz-rich bed at 95.4-95.8 feet which contains quartz (55 percent), muscovite (40 percent), and tourmaline ( 5 percent). Irregular discontinuous quartz stringers, less than 0.1 inch thick, form 1 percent of the core.

Pegmatite.

Albite-quartz-muscovite pegmatite (zone 2, wall zone): Contains albite (53 percent), quartz (40 percent), muscovite ( 5 percent), apatite $(<1$ percent), tourmaline $(<1$ percent), tantalite-columbite (trace), cassiterite(?) (trace), and an unidentified yellowish to greenish-brown mineral (trace). The average grain size is 0.4 inch. About 20 percent of the albite is very fine grained $(<0.05$ inch) and occurs in irregular aggregates as large as 2 inches. The remainder of the albite is blocky to platy and averages about $0.4 \mathrm{inch}$ in grain size. The minimum index of refraction $\left(\mathrm{N}_{\alpha}{ }^{\prime}\right)$ of the blocky to platy albite cleavage fragments is 1.529 at 100.9 , slightly under 1.529 at 102.1 , and is 1.528 at 104.8 and at 109.5 feet. The maximum size of muscovite is 1.25 inches. Black and bluish-black grains of tourmaline range in size from less than 0.05 to 0.15 inch. One bluish-black grain of tourmaline is apparently zoned, with the index of refraction $\left(\mathrm{N}_{\omega}\right)$ ranging from 1.665 to 1.675. Five plates of tantalite-columbite are 0.01 inch thick and 0.03 to 0.1 inch long. One black grain, 0.08 by 0.02 inch, may be cassiterite(?). An unidentified yellowish- to greenish-brown mineral occurs in irregular rounded masses, 0.2 inch in diameter; the mineral is soft and waxy. One grain of the unidentified mineral has a rounded hexagonal shape, indicating that it may be an alteration product of beryl.

Cleavelandite-muscovite pegmatite (zone 3, first intermediate zone): Contains cleavelandite (94 percent), muscovite ( 5 percent), apatite (trace), and tourmaline (trace). The average grain size is 1 inch. The maximum size of recovered muscovite is 1.75 inches.

Cleavelandite pegmatite (zone 5, third intermediate zone): Contains cleavelandite (97 percent), muscovite ( 2 percent), quartz $(<1$ percent), tourmaline $(<1$ percent), apatite $(<1$ percent), tantalite-columbite (trace), and cassiterite(?) (trace). The average grain size is about 1 inch. The minimum index of refraction of cleavelandite $\left(\mathrm{N}_{\alpha}{ }^{\prime}\right)$ is 1.528. The maximum size of muscovite is 1.75 inches. Tourmaline has the following characteristics-pale-blue tourmaline, 0.05 -inch grains, at 112 feet, $\mathrm{N}_{\omega}=1.66$; bluish-black tourmaline, 0.05 -inch grains, at 118.7 feet, $\mathrm{N}_{\omega}=1.66$; and black tourmaline, .75-inch grain, at 118.8 feet, $\mathrm{N}_{\omega}=1.67$. Four black plates of tantalite-columbite are 0.01 to 0.02 inch thick and 0.03 to 0.2 inch long. Several rounded to irregular 0.02 -inch grains are probably cassiterite(?).

Albite-quartz-muscovite pegmatite (zone 2, wall zone): Contains albite (75 percent), quartz (11 percent), muscovite (10 percent), perthite $(2$ percent), tourmaline $(<1$ percent), apatite $(<1$ percent) and tantalite-columbite $(<1$ percent). The core is heavily iron stained. The average grain size decreases from 0.4 inch at 119.5 feet to 0.2 inch at 127 feet. The zone can be subdivided into layers on the basis of mineralogy (see table at end of log). Albite occurs chiefly as subplaty grains; some is sugary grained $(<0.05 \mathrm{inch})$. The minimum index of refraction of cleavage fragments of subplaty albite ranges from slightly less than 1.529 at 119.4 feet to slightly more than 1.529 at 127.6 feet. Perthite between 119.3 and 120.0 feet consists of white to creamy-white 1 -inch grains, embayed and veined by quartz. Muscovite is as long as 1.3 inches. Tourmaline between 120.0 and 120.9 feet occurs as greenish-black grains 0.06 by 0.5 inch, bluish-black grains 0.01 to 0.05 inch, and black grains $\left(\mathrm{N}_{\omega}=1.67\right) 0.15$ inch in diameter. Greenish-black grains $\left(\mathrm{N}_{\omega}=1.66\right), 0.02$ to 0.5 inch, occur between 120.9 and 126.6 feet. Tantalite-columbite plates are as long as 0.15 inch. 
Feet $127.6-130.5$

$130.5-137.9$

\section{Hole 2-Continued}

Description

Quartz-mica-tourmaline schist: Contains quartz (45 percent), muscovite (35 percent), biotite (10 percent), and tourmaline (10 percent). Tourmaline forms 15 percent of the schist at 127.8 feet but decreases to 5 percent at 130.0 feet. The tourmaline $\left(N_{\omega}=1.67\right)$ occurs in black euhedral grains which range in size from 0.01 to $0.1 \mathrm{inch}$. Irregular discontinuous quartz stringers, less than 0.3 inch thick, form less than 5 percent of the core. Lineation of tourmaline needles is $35^{\circ}$ to the core at 129 feet.

Quartz-mica schist: Contains quartz (50 percent), muscovite (30 percent), biotite (20 percent), and tourmaline (trace). Traces of tourmaline occur only at 130.5-131.5 feet. Irregular discontinuous quartz stringers, as much as 2 inches thick, form less than 5 percent of the core.
Angles of intersection of drill core in hole 2 with bedding, schistosity,

\begin{tabular}{|c|c|c|c|c|}
\hline Depth (feet) & Bedding & Schistosity & $\begin{array}{c}\text { Pegmatite } \\
\text { contacts }\end{array}$ & Fractures \\
\hline $\begin{array}{l}16-60 \\
6366.46 \\
62.5 \\
92-100 \\
100.7 \\
100.8 \\
126.8 \\
128 \\
130-130 \\
131.8 \\
134-137.9\end{array}$ & $\begin{array}{r}5-17 \\
10 \\
10-20 \\
45-55 \\
30 \\
15-25 \\
25-30 \\
35 \\
5-15\end{array}$ & \begin{tabular}{|r}
$\begin{array}{r}5-20 \\
135 \\
20\end{array}$ \\
$40-55$ \\
65 \\
(3) \\
215 \\
20
\end{tabular} & $\begin{array}{r}50 ? \\
90 \\
62 \\
50 \\
90 \\
90 \\
9\end{array}$ & 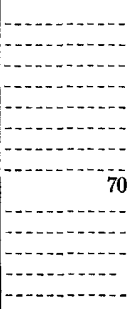 \\
\hline
\end{tabular}
pegmatite contacts, and fractures, in degrees

Mineralogic composition of layers in zone 2 (wall zone) at 66.5270.8 and $119.8-127.6$ feet, hole 2

\begin{tabular}{|c|c|c|c|c|c|c|}
\hline \multirow{2}{*}{$\begin{array}{l}\text { Depth (feet) of } \\
\text { zone and layers } \\
\text { within zone }\end{array}$} & \multirow{2}{*}{$\begin{array}{l}\text { Average } \\
\text { grain } \\
\text { size } \\
\text { (inches) }\end{array}$} & \multicolumn{5}{|c|}{ Principal minerals (estimated percent) } \\
\hline & & $\begin{array}{l}\text { Blocky } \\
\text { to platy } \\
\text { albite }\end{array}$ & $\begin{array}{l}\text { Sugary- } \\
\text { grained } \\
\text { albite }\end{array}$ & Quartz & Muscovite & Perthite \\
\hline $\begin{array}{l}66.52-70.8: \\
\quad 66.52-67.0 \\
\quad 67.0-69.8 \\
69.8-70.8 \ldots \\
\end{array}$ & $\begin{array}{l}0.5 \\
.5 \\
.35\end{array}$ & $\begin{array}{l}<1 \\
30 \\
65\end{array}$ & $\begin{array}{l}-\cdots \\
-\cdots-1\end{array}$ & $\begin{array}{l}75 \\
55 \\
25\end{array}$ & $\begin{array}{r}20 \\
14 \\
8\end{array}$ & - \\
\hline $\begin{array}{l}119.3-127.6: \\
119.3-120.0 \\
120.0-120.9 \\
120.9-127.6\end{array}$ & $\begin{array}{l}.4 \\
.3 \\
.2\end{array}$ & $\begin{array}{l}40 \\
55 \\
75\end{array}$ & 10 & $\begin{array}{r}35 \\
35 \\
5\end{array}$ & $\begin{array}{r}3 \\
6 \\
10\end{array}$ & 20 \\
\hline
\end{tabular}

Hole 3

Location of collar: 151 feet S. $57^{\circ}$ E. of hole 1 , and 329 feet N. $361^{\circ}$ E. of the portal of the adit 0 fthe main underground working of the Peerless mine. Altitude of collar: 4,628 feet.

$$
\text { Feet }
$$

$0-4.5$

4.5-39.2

$39.2-39.5$

$39.5-50.0$

$50.0-55.0$

$55.0-114.4$
Description
Overburden. No core.
Inclination: Minus $20^{\circ}$.

Bearing: S. $631^{\circ} \mathrm{W}$

Length: 331.8 feet.
Quartz-mica-chlorite schist: Contains quartz (45 percent), muscovite (30 percent), biotite (15 percent), chlorite ( 8 percent), garnet (1 percent), and staurolite (trace). Pseudomorphs of muscovite, biotite, and chlorite after euhedral staurolite, 0.1 to $1 \mathrm{inch}$, average about 5 percent of the core. Some of the pseudomorphs contain relicts of brown staurolite. Isolated elongate dark-green flakes of chlorite, 0.05 to 0.25 inch, also occur in the matrix. Metacrysts of reddish-brown garnet are 0.05 to 0.1 inch in diameter. Irregular discontinuous quartz stringers, ranging in thickness from 0.01 to 5 inches, form 5 percent of the core.

Quartz-plagioclase pegmatite: Not shown on the cross section (pl. 6). The only minerals are quartz (75 percent) and plagioclase (25 percent). The quartz is massive and colorless to slightly milky white. White plagioclase grains (average about 0.5 inch) occur in aggregates as large as 1.5 inches.

Quartz-mica-chlorite schist. Similar to the schist at 4.5-39.2 feet. Quartz stringers, 0.1 to 0.75 inch thick, form about 3 percent of the core.

No core. This lack of core and heavy iron staining at 55-60 feet indicate a zone of fractures.

Quartz-mica-chlorite schist: Same as at depth 4.5-39.2 feet. Interbedded with quartz-mica schist. Quartz stringers as at 39.5-50.0 feet. The quartz-mica schist contains quartz (50-60 percent), muscovite (20-25 percent), biotite (10-20 percent), chlorite (0-3 percent), and garnet (trace). Some beds contain as much as 3 percent pseudomorphs of muscovite and biotite after staurolite, but the pseudomorphs are less common than in the quartz-mica-chlorite schist. Beds of quartz-mica schist were cut at 60-64, 68.5-70, 75.5-77.0, 88-88.7, 99.8-101.6, and 109-114.4 feet. At 103.9-109 feet, quartzmica schist beds, 1 to 5 inches thick, constitute about 40 percent of the core. Traces of soft yellowishwhite lath-shaped grains, 0.05 to 0.1 inch long, occur at 113.5-114.4 feet, near the pegmatite contact; these grains consist of unidentified clay minerals and may be altered plagioclase metacrysts. 
Feet

114.4-157.4

$114.40-114.45$

$114.45-122.3$

$122.3-135.2$

$135.2-144.5$

$144.5-148.5$

$148.5-157.2$

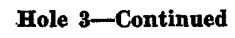

Description

Pegmatite.

Quartz-muscovite pegmatite (zone 1, border zone): Contains quartz (80 percent), muscovite (20 percent), and apatite (trace). A sheet of massive, colorless to slightly smoky quartz, 0.1 to 0.4 inch thick, forms the outer part of the zone adjacent to the schist. The average grain size of the inner part of the zone is 0.05 inch.

Albite-quartz-muscovite pegmatite (zone 2, wall zone): Contains albite (55 percent), quartz (35 percent), muscovite ( 8 percent), unknown alteration products of phosphate minerals ( 1 percent), beryl ( 0.12 percent of 7.75 feet of recovered core), tourmaline ( $<1$ percent), apatite (trace), tantalite-columbite (trace), loellingite? (trace), and garnet (trace). Individual grains average 0.35 inch and aggregates about 0.75 inch. The zone can be subdivided into layers on the basis of mineralogy (see table at end of log).

Albite is white, grayish, and buff or reddish stained. Minimum index of refraction of cleavage fragments $\left(\mathrm{N}_{\alpha}^{\prime}\right)$ is 1.528. Muscovite grains have a maximum dimension of 2.25 inches. Four beryl crystals are exposed in this segment of wall zone and are described in table at end of log.

Three grains of tantalite-columbite are 0.01 inch thick and 0.1 to 0.2 inch long. Dark-brown to black unknown alteration products of phosphate minerals stain the core. One buff-silvery penetration twin, 0.3 inch in diameter, is tentatively identified as loellingite(?). A rounded reddish-brown grain of garnet $(\mathrm{N}=1.82)$ is 0.25 by 0.15 inch.

Cleavelandite-muscovite-quartz pegmatite (zone 3 , first intermediate zone): Contains cleavelandite (55 percent), muscovite (35 percent), quartz ( 8 percent), tourmaline $(<1$ percent), apatite (trace), and cassiterite (trace). The average grain size increases from 0.75 inch at 122.5 feet to 2 inches at 133 feet. The maximum size of muscovite books recovered in the core is 8.5 inches, and the average size is about 3 inches. The muscovite is ruled and contains "herringbone" structures. Bluish- and greenish-black, euhedral to subhedral grains of tourmaline range in size from 0.01 to 0.35 inch. Four irregular grains of cassiterite, ranging in size from 0.05 to 0.65 inch, occur along the edges of muscovite books.

Cleavelandite-quartz pegmatite (zone 5 , third intermediate zone): Contains cleavelandite (86 percent), quartz (10 percent), apatite ( 2 percent), muscovite ( 1 percent), tourmaline ( $<1$ percent), and an unidentified altered phosphate mineral (trace). Individual grains average about 1 inch. Quartz occurs as a massive pod at 141.6-142.2 feet, but forms less than 1 percent of the rest of the core. Cleavelandite $\left(\mathrm{N}_{\alpha}{ }^{\prime}=1.528\right)$ occurs in aggregates as large as 15 inches in diameter. Eight subhedral to rounded grains of apatite (manganapatite?), pale green to dark bluish-green, occur at 135.75-136.0 feet; these range in size from 0.2 to 1.5 inches and average 0.75 inches; $\mathrm{N}_{\omega}=1.654$, $\mathrm{N}_{\varepsilon}=1.651$. Blue to bluish-black euhedral tourmaline grains average 0.05 inch. An irregular 0.5-inch aggregate at $\mathbf{1 4 4 . 4}$ feet consists of a claylike pinkish-buff material, surrounded by a halo of brown stains in the surrounding cleavelandite; the claylike material was not identified, probably it is an altered phosphate mineral.

Muscovite-cleavelandite pegmatite (zone 3, first intermediate zone) : Contains muscovite (85 percent), cleavelandite (10 percent), beryl (2.61 percent of 2.9 feet of recovered core), quartz ( 2 percent), apatite (trace), and tourmaline (trace). The average grain size is about 8 inches. Muscovite books are as large as 18 inches in maximum dimension. One large prismatic grain of beryl, 3.75 inches long and 1 inch thick, occurs at $144.7-145.0$ feet. The beryl $\left(\mathrm{N}_{\omega}=1.582\right)$ is pale milky white, with a very faint greenish tint.

Albite-quartz-muscovite pegmatite (zone 2, wall zone): Contains albite (63 percent), quartz (25 percent), muscovite ( 5 percent), perthite (4 percent), tourmaline ( 1 percent), unknown alteration products of phosphate minerals ( 1 percent), beryl ( 0.33 percent of 7.95 feet of recovered core), apatite ( $<0.5$ percent), tantalite-columbite (trace), unidentified bluish- to dark-green mineral (trace), amblygonite-montebrasite(?) (trace), and loellingite(?) (trace). The overall average grain size of this segment of wall zone is about $0.75 \mathrm{inch}$. The zone can be subdivided into layers on the basis of mineralogy (see table at end of log).

Most of the albite is blocky to platy. Sugary-grained albite $(<0.1$ inch) occurs as irregular aggregates and discontinuous layers 0.25 to 4 inches thick. Perthite occurs only as a 5-inch fleshy-white grain at $\mathbf{1 5 1 . 5}$ feet that is veined and embayed by albite and quartz. Tourmaline is black to bluish-black and subhedral to euhedral. Bluish-green subhedral to rounded grains of apatite average 0.05 inch. Four plates of tantalite-columbite are all less than 0.1 inch in length.

An unidentified bluish- to dark-green soft mineral occurs in 0.1-inch angular clots with a graphic texture in albite; microscopically the mineral is a very fine grained aggregate with an index of refraction of 1.58 .

Dark-brown and black unknown alteration produts of phosphate minerals occur as heavy stains, and several 0.2-inch grains consisting mostly of brown limonitic fine-grained aggregates are probably highly altered phosphate minerals. Traces of white amblygonite-montebrasite(?) occur in these heavily stained aggregates; microscopically this mineral is very finely crystalline, and 
Feet

$157.2-157.4$

$157.4-187.2$

$187.2-331.8(?)$

$187.20-187.25$

$187.25-311.1$

$311.1-322.1$

322.1-323.1

323.1-331.8

331.8
Hole 3-Continued

Description

Pegmatite-Continued

has a maximum index of refraction of about 1.62. Eight beryl crystals are exposed in this segment of wall zone and are described in table at end of log.

Quartz-muscovite-albite pegmatite (zone 1, border zone). Contains quartz (59 percent), muscovite (30 percent), albite (10 percent), beryl ( 0.42 percent of 0.2 feet of recovered core), apatite $(<0.5$ percent), and tantalite-columbite (trace). The average grain size is $0.1 \mathrm{inch}$. The average size of muscovite decreases from 0.15 inch at 157.2 feet to 0.05 inch at 157.4 feet, and the percentage of muscovite increases from 15 percent at 157.2 feet to 40 percent near the schist contact. White blocky to subplaty grains of albite $\left(\mathrm{N}_{\alpha}{ }^{\prime}=1.530\right), 0.05$ to 0.5 inch, occur only from 157.2 to 157.3 feet. A cluster of 0.1-inch beryl crystals occurs at 157.2; $\mathrm{N}_{\omega}=1.579$. Four colorless to white, buff-stained, subhedral crystals of beryl at 157.3-157.35 feet range in maximum dimension from less than 0.1 to $0.5 \mathrm{inch} ; \mathrm{N}_{\omega}=1.577$. The maximum size of bluish-green apatite is $0.07 \mathrm{inch}$. One grain of tantalite-columbite, 0.15 by 0.01 inch, was noted.

Quartz-mica schist: Similar to the schist at 55.0-114.4 feet except that at 157.4-157.6 feet and at 185.9187.2 feet adjacent to pegmatite contacts, the schist contains very little biotite and is relatively rich in muscovite. Quartz stringers, 0.05 to 1 inch thick, form 5 percent of the rock.

Pegmatite.

Quartz-muscovite pegmatite (zone 1, border zone): Very fine grained (0.1 inch). Contains quartz ( 76 percent), muscovite ( 20 percent), albite ( 3 percent), and apatite $(0.5$ percent).

Albite-quartz-muscovite pegmatite (zone 2, wall zone): Contains albite (57 percent), quartz (30 percent), muscovite ( 5 percent), perthite $(4$ percent), tourmaline ( 1 percent), amblygonite-montebrasite $(<1$ percent), unidentified phosphate minerals and their alteration products $(<1$ percent), lithia mica $(<1$ percent), beryl $(0.01$ percent of 118 feet of recovered core), cassiterite $(<0.5$ percent), apatite $(<0.5$ percent), tantalite-columbite $(<0.5$ percent), dahllite (trace), triploidite(?) (trace), unidentified dark-gray to green mineral (trace), and loellingite(?) (trace). The grain size which varies greatly averages about 0.3 inch. Sugary-grained aggregates and discontinuous layers consisting predominantly of albite (70 percent) and quartz ( 25 percent) a verage 0.05 inch. The grain size of the rest of the zone is generally less than $1 \mathrm{inch}$, but perthite-rich pegmatite averages as much as 3 inches at 295 feet. The zone can be subdivided into layers on the basis of mineralogy and grain size (see table at end of log).

Albite occurs both as blocky to platy grains and as sugary grains. Minimum indices of cleavage fragments $\left(\mathrm{N}_{\alpha}{ }^{\prime}\right)$ of blocky to platy albite range from 1.530 at 187 feet to 1.528 at 310 feet. Sugarygrained albite at 244 feet has $\mathrm{N}_{\alpha}^{\prime}=1.529$. Flesh-colored crystals of perthite, 0.3 to 8 inches long, are embayed and veined by albite and quartz. Seven iron-stained, pale-white euhedral crystals of beryl $\left(\mathrm{N}_{\omega}=1.579\right), 0.01$ to 0.09 square inch in area, occur at 188 feet. At 306.7 feet two milkywhite subhedral grains of beryl, 0.15 by 0.25 inch and 0.25 by $0.4 \mathrm{inch}$, have $\mathrm{N}_{\omega}=1.580$. At 308.1 feet a similar beryl grain, 0.5 by 0.85 inch, has $\mathrm{N}_{\omega}=1.579$. Grayish-white amblygonite-montebrasite occurs as grains having a maximum length of 3 inches; $\mathrm{N}_{\gamma}{ }^{\prime}=1.62$. Dahllite (carbonateapatite). occurs as a buff-white mineral, as much as 0.25 inch in diameter, at 194 and 222.5 feet; uniaxial (-); $\mathrm{N}_{\omega}=1.64$; birefringence, 0.005 .1

Grayish-, clove-, yellowish-brown, and black unidentified phosphate minerals occur as irregular clots and streaks, 0.1 to 1.5 inches, and their alteration products stain the other minerals in the core. Triploidite(?) occurs as a yellowish-brown irregular aggregate, 1.5 by 0.6 inches, at 187.8 feet.

Tantalite-columbite and cassiterite grains are less than 0.25 inch in maximum dimension. Tourmaline occurring as bluish-black to black subhedral to euhedrai grains as much as 1 inch long forms a maximum of 15 percent of the core at 263.5-264.6 feet. About 1 percent of the core from 292.7-302.4 feet consists of irregular fracture fillings, 0.1 to 3 inches thick, composed of very fine yellowish to grayish-yellow mica (probably a lithia mica).

Quartz-cleavelandite-muscovite pegmatite (zone 3, first intermediate zone): Contains quartz (49 percent), cleavelandite ( 25 percent), muscovite ( 25 percent), beryl ( 0.03 percent of 9.2 feet of recovered core), tourmaline (trace), apatite (trace); tantalite-columbite (trace), and dahllite (trace). The average grain size is about 1.5 inches. The maximum size of muscovite is 7 inches, and the average size of recovered books is 3 inches. A yellowish-white prismatic crystal of beryl $\left(\mathrm{N}_{\omega}=1.582\right)$ at 317.3 feet is 0.6 by 0.1 inch.

The core is considerably fractured and iron stained from 311.1 to 322.1 feet. Pyrite and chalcopyrite, in grains ranging in size from 0.5 to $0.25 \mathrm{inch}$, occur along and near some of the fractures, and a powdery-blue mineral is associated with some of the chalcopyrite. Vuggy cavities near some of the fractures are lined with quartz crystals, 0.1 to 0.75 inch in length; other small vugs are filled with limonite.

No core recovered.

Cavity. In fault zone.

Hole abandoned.

${ }^{1}$ Identifled by A. J. Gude, 3d, U. S. Geol. Survey, using X-ray powder technique. 
Hole 3-Continued

Angles of intersection of drill core in hole 3 with bedding, schistosity, pegmatite contacts, and fractures, in degrees

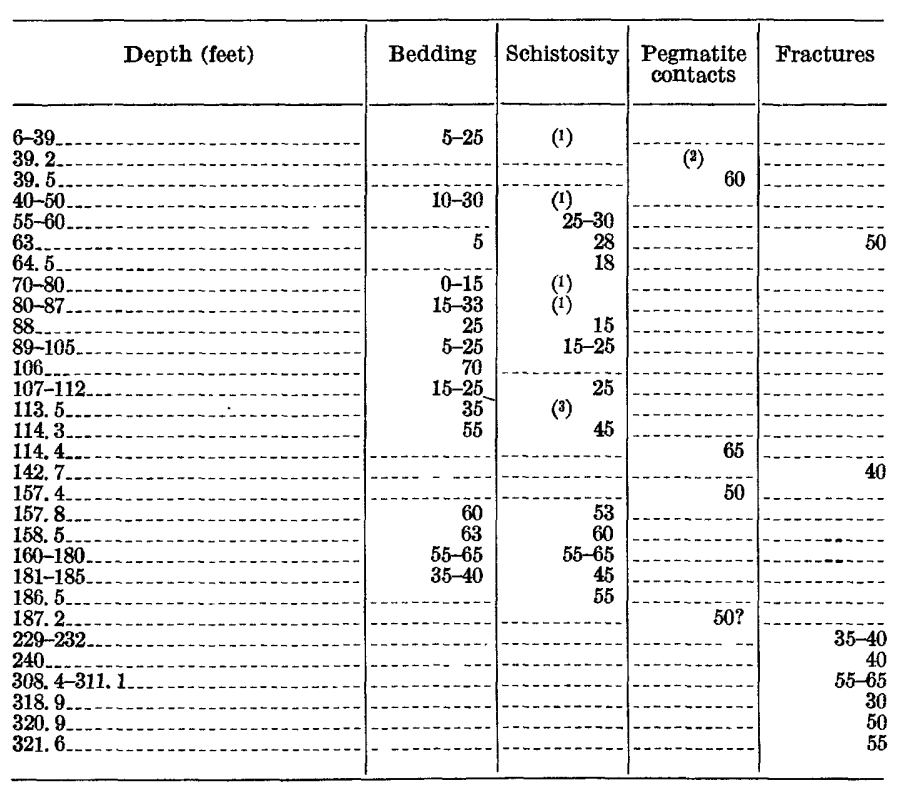

1 Approximately parallel to beds. 3 Parallel to beds.
Mineralogic composition of layers in zone 2 (wall zone) at 114.45-122.3, 148.5-157.2, and 187.25-311.1 feet, hole 3

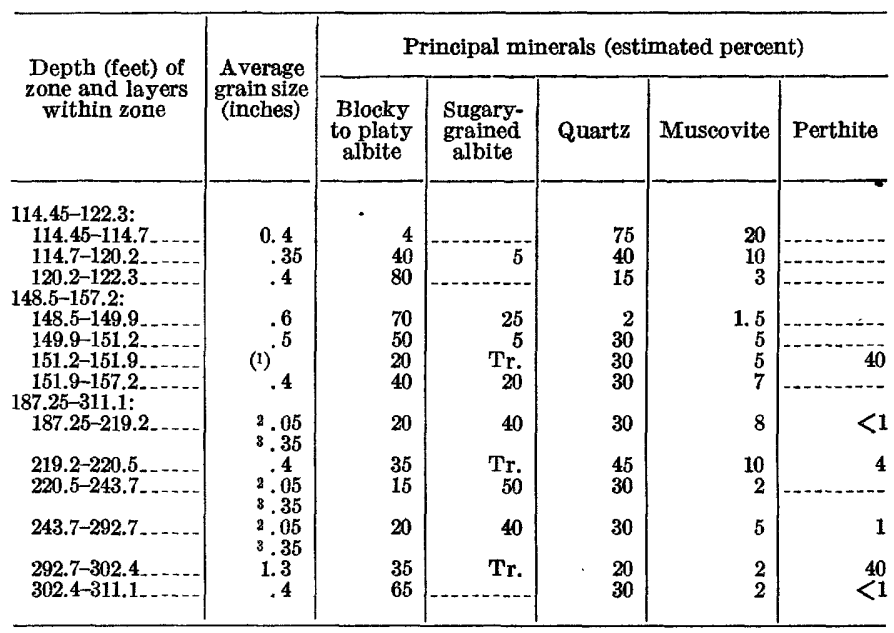

15 -inch perthite crystal in 0.3-inch groundmass.

2 Sugary-grained phase.

Description of beryl crystals in zone 2 (wall zone) at 114.45-122.3 and 148.5-157.2 feet, hole 3

\begin{tabular}{|c|c|c|c|c|c|}
\hline \multicolumn{2}{|c|}{ Depth (feet) } & \multirow{2}{*}{$\begin{array}{c}\text { Dimensions } \\
\text { (inches) }\end{array}$} & \multirow{2}{*}{ Shape } & \multirow{2}{*}{ Color } & \multirow{2}{*}{$\mathrm{N \omega}$} \\
\hline Zone & $\begin{array}{c}\text { Beryl } \\
\text { crystal }\end{array}$ & & & & \\
\hline \multirow[t]{3}{*}{$114.45-122.3$} & 114.46 & (1) & $\begin{array}{l}\text { Rounded, } \\
\text { subhedral }\end{array}$ & $\begin{array}{c}\text { White, iron } \\
\text { stained }\end{array}$ & 1.579 \\
\hline & 114.5 & 0.15 by 0.4 & $\begin{array}{l}\text { Elongate, } \\
\text { euhedral } 2\end{array}$ & $\ldots \mathrm{do}$ & $\ldots$ \\
\hline & $\begin{array}{l}114.5 \\
119.0\end{array}$ & $\begin{array}{l}.15 \text { by } .5 \\
.5 \text { by } 1.05\end{array}$ & $\begin{array}{l}\text { Elongate } \\
\text { Prismatic }\end{array}$ & Milky white & $\begin{array}{l}1.577 \\
1.583\end{array}$ \\
\hline \multirow[t]{6}{*}{$148.5-157.2$} & 150.1 & 1.0 by 2.0 & $\begin{array}{c}\text { Rounded, } \\
\text { prismatic }\end{array}$ & $\begin{array}{l}\text { White with } \\
\text { colorless to } \\
\text { faint-green } \\
\text { portions. }\end{array}$ & 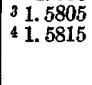 \\
\hline & $\begin{array}{l}150.35 \\
150.4\end{array}$ & .15 by 1.1 & $\begin{array}{l}\text { Anhedral } \\
\text { Subhedral }\end{array}$ & Iron stained & 1.582 \\
\hline & 150.45 & .3 by .75 & $\begin{array}{l}\text { Rounded, } \\
\text { prismatic }\end{array}$ & $\begin{array}{l}\text { Colorless to } \\
\text { white, stained } \\
\text { along fractures. }\end{array}$ & 1.582 \\
\hline & $\begin{array}{l}150.5 \\
152.45\end{array}$ & $\begin{array}{l}.3 \text { by } .75 \\
.25 \text { by } . .3\end{array}$ & $\begin{array}{l}\text { Subhedral } \\
\text { Rounded, }\end{array}$ & Milky to color- & $\begin{array}{l}1.582 \\
1.582\end{array}$ \\
\hline & 100.00 & & prismatic & $\begin{array}{l}\text { less, stained } \\
\text { buff to yellow- } \\
\text { ish brown. }\end{array}$ & \\
\hline & $\begin{array}{l}152.5 \\
152.5\end{array}$ & $\begin{array}{lll}.1 & \text { by } & .2 \\
.2 & \text { by } & .25\end{array}$ & -...do. do & do do & $\begin{array}{l}1.582 \\
1.582\end{array}$ \\
\hline
\end{tabular}

1 Area, 0.01 square inch.

2 Crystal oriented perpendicular to layering.

3 In center.

Atea, 0.02 square inch.
5 Arend 
Toostion: 97 feet B. $86^{\circ}$ E. from hole 3 . Altitude of collar: 4,600 feet. Inclination: $0^{\circ}$.

seet

$0-12.6$

$12.6-45.8$

$45.8-72.0$

$72.0-74.7$

$74.7-77.2$

$74.7-75.0$

$75.0-77.1$

$77.1-77.2$

$77.2-139.5$

$139.5-141.7$

139.5-139.9

139.9-141.6

$141.6-141.7$

141.7-149.2

149.2-149.7

$426709-57-4$
Hole 4.

Bearing: 8. $6312^{\circ} \mathrm{W}$ Length: 327.2 feet.

Description

Overburden and schist. No core.

Quartz-mica-staurolite schist: Contains quartz ( 45 percent), muscovite ( 30 percent), biotite ( 15 percent), staurolite (6 percent), chlorite ( 3 percent), garnet $(<1$ percent), and andalusite $(<1$ percent). Brown metacrysts of staurolite range in length from 0.1 to 0.75 inch. Pseudomorphs of muscovite, biotite, and chlorite after euhedral staurolite increase in abundance with depth; at 42-45.8 feet, about 50 percent of the staurolite metacrysts are mica pseudomorphs. Andalusite occurs sparingly as tabular pinkish metacrysts, 0.5 to 1.75 inches in length, and is rimmed by a white fine micaceous material; several irregular 1.5-inch patches of the white fine micaceous material at 25 feet are probably pseudomorphous after andalusite. Irregular discontinuous quartz stringers, ranging in thickness from 0.05 to 0.75 inch, form less than 5 percent of the core.

Quartz-mica-chlorite schist: Contains quartz (44 percent), muscovite (34 percent), biotite (15 percent), chlorite ( 5 percent), staurolite $(<1$ percent), garnet $(<1$ percent), tourmaline $(<1$ percent), and andalusite (trace). Pseudomorphs of muscovite, biotite, and chlorite after euhedral staurolite, comprise 5 to 10 percent of the core; relict staurolite within these pseudomorphs decreases in amount with depth. Several 2-inch aggregates of white very fine micaceous material at 50-55 feet contain traces of pink andalusite. Black euhedral tourmaline grains, 0.03 inch in length, form about 3 percent of the core at 70.5-72.0 feet. Quartz stringers, 0.1 to 1 inch thick, form less than 5 percent of the core.

Quartz-mica-tourmaline schist: Contains quartz (44 percent), muscovite (40 percent), tourmaline (10 percent), biotite ( 5 percent), garnet $(<1$ percent), and chlorite $(<1$ percent). Mica pseudomorphs after staurolite form about 4 percent of the core. Black euhedral grains of tourmaline are 0.01 to 0.04 inch long. Quartz stringers, 0.1 to 0.5 inch thick, form about 5 percent of the core.

Pegmatite.

Quartz-muscovite pegmatite (zone 1, border zone): Contains quartz (85 percent), muscovite (15 percent), tourmaline (trace), and apatite (trace). The average grain size is about 0.2 inch but some of the quartz is massive.

Quartz-albite-muscovite pegmatite (zone 2, wall zone): Contains quartz (59 percent), albite (25 percent), muscovite (14 percent), beryl ( 0.92 percent of 2.05 feet of recovered core), and apatite ( $<0.5$ percent). Average grain size is about $0.6 \mathrm{inch}$. The minimum index of refraction $\left(\mathrm{N}_{\alpha}{ }^{\prime}\right)$ of subplaty albite at 75.8 feet is 1.530 . The maximum size of muscovite is 1.75 inches, but the average is 0.4 inch. Pale-milky-white beryl occurs in 14 euhedral grains, which range in length from 0.1 to 1 inch, at 75.6-77.0 feet. Two grains at 76.4 feet have $\mathrm{N}_{\omega}=1.578$, but grains at 76.6 to 77.0 feet have $N_{\omega}$ ranging from 1.574 to 1.577 . Green rounded grains of apatite $\left(N_{\omega}=1.64\right)$ range in size from less than 0.05 to 0.25 inch.

Quartz-muscovite pegmatite (zone 1, border zone): Contains quartz (85 percent), muscovite (14 percent), tourmaline (1 percent), and apatite (trace). A layer of massive quartz at the schist contact is 0.3 inch thick. The rest of the zone has an average grain size of $0.1 \mathrm{inch}$.

Quartz-mica schist: Contains quartz (45-60 percent), muscovite (25-35 percent), biotite (10-20 percent), tourmaline (trace), and chlorite (trace). Rich in muscovite and contains little biotite at 77.2-77.4 feet. About 3 percent of the core consists of muscovite and biotite pseudomorphs after euhedral staurolite ranging in length from 0.05 to 1.5 inches. Some of pseudomorphs have well-defined museovite centers and biotite rims. Traces of black tourmaline, less than 0.05 inch long, occur at 77.2-79 feet. Quartz stringers as much as 2 inches thick constitute less than 5 percent of the core.

Pegmatite.

Quartz-muscovite pegmatite (zone 1, border zone): Contains quartz (85 percent), muscovite (12 percent), albite ( 2 percent), and apatite $(<1$ percent). A layer of massive quartz, 0.5 inch thick is at the schist contact. The rest of the zone averages about 0.15 inch in grain size.

Albite-quartz-muscovite pegmatite (zone 2, wall zone): Contains albite (48 percent), quartz (40 percent), muscovite (10 percent), tourmaline ( 1 percent), beryl ( 0.08 percent of 1.7 feet of recovered core), apatite (trace), and cassiterite? (trace). The average grain size is about 0.5 inch. The maximum size of muscovite is 0.7 inch. Bluish-black euhedral to subhedral grains of tourmaline range in size from less than 0.05 to 0.25 inch. Two buff-white euhedral grains of beryl $\left(\mathrm{N}_{\omega}=1.580\right)$ at 141.2 feet are 0.15 and 0.13 inch in diameter. Several brownish-black rounded grains, 0.1 to 0.2 inch in diameter, may be cassiterite.

Quartz-muscovite pegmatite (zone 1, border zone): Contains quartz (80 percent), muscovite (17 percent), albite ( 2 percent), and apatite ( $<1$ percent). A layer of massive quartz, 0.15 inch thick, is adjacent to the schist contact. The average grain size of the rest of the zone is about $0.1 \mathrm{inch}$. Quartz-mica schist: Similar to schist at 77.2-139.5 feet.

Quartz-mica-tourmaline schist: Similar to schist at 72.0-74.7 feet. Black euhedral tourmaline $\left(\mathrm{N}_{\omega}=\right.$ 1.672) grains range in size from 0.05 to 0.5 inch, 
Feet

149.7-159.6

$149.7-149.8$

$149.8-159.3$

159.3-159.6

159.6-163.3

163.3-185.3

$185.3-200.9$

200.9-201.3

201.3-260.6

$260.6-327.2$

260.6-260.8

260.8-272.2

272.2-277.1

\section{Hole 4-Continued}

Description

Pegmatite.

Quartz-muscovite pegmatite (zone 1, border zone): Contains quartz (80 percent), muscovite (16 percent), albite ( 3 percent), and apatite ( $<1$ percent). Albite occurs only at 149.8 feet. Very fine grained (0.1 inch).

Albite-quartz-muscovite pegmatite (zoné 2, wall zone): Contains albite ( 75 percent), quartz (18 percent), muscovite ( 6 percent), beryl ( 0.18 percent of 9.5 feet of recovered core), tourmaline ( $<1$ percent), apatite (trace), tantalite-columbite (trace), and an unidentified bluish- to greenishgray mineral (trace). Average grain size is about 0.5 inch. The maximum size of muscovite is 1 inch. Bluish- and greenish-black, subhedral to euhedral grains of tourmaline range in length from 0.1 to 0.75 inch. Three plates of tantalite-columbite are 0.01 by 0.05 inch. A bluish- to greenish-gray soft mineral, probably an altered phosphate, occurs in rounded grains, 0.05 to 0.3 inch in diameter. Nine grains of beryl are exposed in this segment of wall zone and are described in table at end of $\log$.

Quartz-muscovite pegmatite (zone 1, border zone): Contains quartz (70 percent), muscovite (25 percent), albite (3 percent), and apatite ( 2 percent). Very fine grained ( 0.1 inch). The minimum index of refraction $\left(\mathrm{N}_{\alpha}{ }^{\prime}\right)$ of albite at 159.45 feet is 1.530 . Bluish-green grains of apatite range in size from 0.01 to 0.1 inch.

Quartz-mica-tourmaline schist: Contains quartz (44 percent), muscovite (35 percent), biotite (15 percent), tourmaline (5 percent), garnet $(<1$ percent), and apatite $(<1$ percent). At $159.6-159.7$ feet, muscovite forms 50 percent of the schist, and there is no biotite; biotite increases away from the contact. Black euhedral grains of tourmaline average about 0.05 inch in diameter and 0.25 inch in length. Bluish-green grains of apatite $\left(\mathrm{N}_{\omega}=1.63\right)$ are 0.05 inch in size. Brown-red grains of garnet, 0.15 inch in diameter, occur at $159.6-160.1$ feet.

Quartz-mica schist: Similar to schist at 77.2-139.5 feet. Quartz stringers are 0.05 to 0.5 inch thick.

Quartz-mica-chlorite schist: Contains quartz (45 percent), muscovite (30 percent), biotite (20 percent), and chlorite (5 percent). Muscovite, biotite, and chlorite pseudomorphs after euhedral staurolite ranging from 0.1 to $0.75 \mathrm{inch}$ in length, form about 5 percent of the core. A quartz stringer, 2.5 inches thick, cuts the schist at 199.9 feet. Irregular discontinuous quartz stringers, 0.05 to 1 inch thick, form less than 5 percent of the core.

Quartz-plagioclase pegmatite: Contains quartz (92 percent), plagioclase ( 6 percent), muscovite ( 2 percent), and tourmaline? (trace). The plagioclase is oligoclase-andesine $\left(\mathrm{An}_{20} ; \mathrm{N}_{\alpha}{ }^{\prime}=1.543\right)$; it occurs in 0.5 -inch grains set in a matrix of massive colorless to milky-white quartz. Muscovite flakes average about 0.4 inch. This pegmatite stringer is too small to be shown in cross section (pl. 6), and may not be connected to the main body of the Peerless pegmatite.

Quartz-mica-chlorite schist: Interbedded with quartz-mica schist. Quartz stringers form about 5 percent of the core. The composition of the quartz-mica-chlorite schist is the same as at 185.3-200.9 feet. The composition of the quartz-mica schist beds is the same as at 77.2-139.5 and 163.3-185.3 feet.

Quartz-mica-chlorite schist occurs from 201.3 to 220.3 feet. At 220.3-240.6 feet, quartz-mica schist, in 1- to 6-inch beds, forms 40 percent of the core and is interbedded repeatedly with beds of quartz-mica-chlorite schist. Quartz-mica schist occurs from 240.6 to 260.6 feet.

Pegmatite.

Quartz-muscovite pegmatite (zone 1, border zone): Contains quartz (64 percent), muscovite (35 percent), and apatite ( 1 percent). Very fine grained $(0.1$ inch). At 260.7 feet a vuggy layer of 0.05 -inch quartz crystals is at an angle of $70^{\circ}$ to the core.

Albite-quartz-perthite pegmatite (zone 2, wall zone): Contains albite (50 percent), quartz (25 percent), perthite ( 10 percent), muscovite (9 percent), tourmaline ( 4 percent), beryl $(0.06$ percent of 10.7 feet of recovered core), apatite ( $<1$ percent), tantalite-columbite (trace), and garnet (trace). The grain size averages about 0.7 inch, but varies widely. The zone can be subdivided into layers on the basis of mineralogy and grain size (see table at end of $\log$ ).

Albite occurs as blocky to platy grains, and also as sugary-grained aggregates up to 2 inches across. The minimum index of cleavage fragments $\left(\mathrm{N}_{\alpha}^{\prime}\right)$ from a subplaty grain at 260.8 feet is 1.530 , and the index from a platy grain at 261.7 feet is 1.529. An elongate euhedral grain of buff-stained pale-white beryl $\left(\mathrm{N}_{\omega}=1.579\right), 0.25$ by 1 inch, is at 260.9 feet. A pale-greenish-white subhedral grain of beryl $\left(\mathrm{N}_{\omega}=1.580\right), 0.35$ by 0.2 inch, occurs at 266.6 feet. Flesh-colored perthite grains, 0.5 to 12 inches in maximum dimension, are embayed by albite, quartz, and muscovite. The maximum size of muscovite books is 1.75 inches. Bluish-black to black tourmaline $\left(\mathrm{N}_{\omega}=\right.$ 1.67) oceurs as euhedral grains as much as 0.5 inch long, and also as aggregates as much as 4 inches in maximum dimension. Some of the larger aggregates of tourmaline between 271.5 and 272.2 feet are veined by quartz. A 1.5-inch aggregate of tourmaline at 262.7 feet is associated with red garnet $(\mathrm{N}=1.82)$ in 0.25 -inch grains. Six platy grains of tantalite-columbite were recognized; the maximum length is 0.1 inch.

Quartz-cleavelandite-muscovite pegmatite (zone 3, first intermediate zone): Contains quartz (36 percent), cleavelandite ( 31 percent), muscovite $(31$ percent), tourmaline (1 percent), and apatite 
Feet

$277.1-303.2$

$303.2-327.2$

\author{
Hole 4-Continued
}

Description

Pegmatite-Continued

( $<1$ percent). Average grain size is about 2 inches. The maximum size of muscovite books is 8 inches and the average about 3 inches. Black grains of tourmaline are 0.05 to 1 inch long. The bluish-green apatite grains reach a maximum of 0.2 inch.

Quartz-cleavelandite pegmatite (zone 5, third intermediate zone): Contains quartz (56 percent), cleavelandite (40 percent), muscovite ( 3 percent), tourmaline $(<0.5$ percent), cassiterite (trace), and apatite (trace). Individual grains average about 1 inch and aggregates about 2.5 inches. The maximum size of cleavelandite aggregates is 8 inches and of muscovite books is 0.2 inch. Greenish- and bluish-black tourmaline occurs in euhedral to subhedral grains, 0.05 to 0.75 inch in length. Five grains of cassiterite range in diameter from 0.05 to $0.2 \mathrm{inch}$. The core from 302.0 to 303.2 feet is iron stained and broken; probably it is in the main fault zone.

Quartz-pegmatite (zone 6b, fourth intermediate zone): Consists wholly of colorless to milky-white massive quartz. The core is broken and iron stained, and core recovery was low. Probably the main fault zone is from 302 to 305 feet, and many subsidiary fractures cut the rock from 305 to 327.2 feet.

Angles of intersection of drill core in hole 4 with bedding, schistosity, and pegmatite contacts, in degrees

\begin{tabular}{|c|c|c|c|}
\hline Depth (feet) & Bedding & Schistosity & $\begin{array}{l}\text { Pegmatite } \\
\text { contacts }\end{array}$ \\
\hline $\begin{array}{l}18-25 \\
34.555 \\
61.53 \\
77.2 \\
80 \\
89\end{array}$ & \begin{tabular}{r}
$15-30$ \\
20 \\
$20-40$ \\
60 \\
$70-76$ \\
40 \\
30 \\
15 \\
$55-60$ \\
30 \\
$30-40$ \\
50 \\
$60-70$ \\
$30-50$ \\
65 \\
45 \\
\\
\hdashline 50 \\
25 \\
70 \\
$45-50$
\end{tabular} & 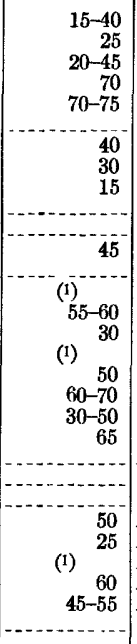 & 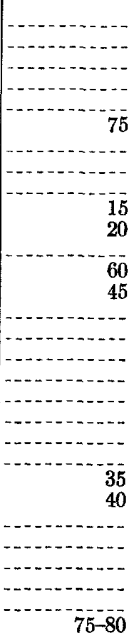 \\
\hline
\end{tabular}

1 Parallel to beds.

Location of collar: 340 feet S. $72^{\circ} \mathrm{W}$. of hole 3 , and 205 feet N. $39^{\circ} \mathrm{W}$. of the portal of the adit of the main underground workings of the Peerless mine.

Altitude of collar: 4,580 feet. Feet

$0-15.0$ $15.0-60.9$

Overburden and schist. No core.
Mineralogic composition of layers in zone 2 (wall zone), 260.8272.2 feet, hole 4

\begin{tabular}{|c|c|c|c|c|c|c|c|}
\hline \multirow{2}{*}{$\begin{array}{l}\text { Depth } \\
\text { (feet) }\end{array}$} & \multirow{2}{*}{$\begin{array}{l}\text { Aver- } \\
\text { age } \\
\text { grain } \\
\text { size } \\
\text { (inches) }\end{array}$} & \multicolumn{6}{|c|}{ Principal minerals (estimated percent) } \\
\hline & & $\begin{array}{l}\text { Blocky } \\
\text { to } \\
\text { platy } \\
\text { albite }\end{array}$ & $\begin{array}{l}\text { Sugary } \\
\text { grained } \\
\text { albite }\end{array}$ & Quartz & $\begin{array}{c}\text { Musco- } \\
\text { vite }\end{array}$ & Perthite & $\begin{array}{c}\text { Tourma- } \\
\text { line }\end{array}$ \\
\hline $\begin{array}{l}260.8-264.8 \\
264.8-269.3 \\
269.3-270.6 \\
270.6-272.2\end{array}$ & $\begin{array}{r}0.5 \\
(1) \\
.3 \\
.6\end{array}$ & $\begin{array}{l}55 \\
40 \\
55 \\
45\end{array}$ & $\begin{array}{r}5 \\
3 \\
15\end{array}$ & $\begin{array}{l}25 \\
25 \\
25 \\
25\end{array}$ & $\begin{array}{r}13 \\
6 \\
5 \\
5\end{array}$ & 25 & $\underset{\text { Tr. }}{<} \underset{25}{1}$ \\
\hline
\end{tabular}

1 Perthite grain, 3 inches long, in 0.4-inch groundmass.

Description of beryl crystals in wall zone at 149.8-159.3 feet, hole 4

\begin{tabular}{|c|c|c|c|c|}
\hline $\begin{array}{l}\text { Depth } \\
\text { (feet) }\end{array}$ & $\begin{array}{c}\text { Size } \\
\text { (square inches) }\end{array}$ & Shape & Color & $\mathrm{N} \omega$ \\
\hline $\begin{array}{l}150.4 \\
150.8 \\
151.2 \\
151.2 \\
151.2 \\
155.8 \\
155.8 \\
155.8 \\
157.9\end{array}$ & $\begin{array}{r}10.25 \text { by } 1.15 \\
1.2 \text { by } .4 \\
.01 \\
.01 \\
.10 \\
.02 \\
.04 \\
.04 \\
1.4 \text { by } 1.5\end{array}$ & $\begin{array}{l}\text { Prismatic } \\
\text { Subhedral } \\
\text { Roundo..... } \\
\text { do do } \\
\text { Euhedral }\end{array}$ & $\begin{array}{l}\text { Milky white to faintly green. } \\
\text { Buff stained. } \\
\text { Buff white. }\end{array}$ & $\begin{array}{l}1.580 \\
1.579 \\
1.582 \\
1.580 \\
1.580 \\
1.580 \\
1.579\end{array}$ \\
\hline
\end{tabular}

Hole 5

Inclination: $0^{\circ}$.

Bearing: N. $6312^{\circ} \mathrm{E}$.

Length: 256.6 feet.

Description

Quartz-mica-chlorite schist: Interbedded with quartz-mica schist. The estimated composition of the quartz-mica-chlorite schist is quartz (45 percent), muscovite (25-30 percent), biotite (15-20 percent), chlorite (4-10 percent), and garnet (0.5 percent). Pseudomorphs of muscovite, biotite, and chlorite after euhedral staurolite, ranging from 0.05 to $1 \mathrm{inch}$ and averaging 0.4 inch in diameter, comprise as much as 10 percent of individual beds; the average is about 4 percent. Some pseudomorphs contain relicts of brown staurolite; others have chlorite centers and muscovite or biotite rims; and others are aggregates of muscovite flakes. The mica flakes are about $0.05 \mathrm{inch}$ in diameter in the pseudomorphs, but only 0.02 inch in the matrix. Isolated elongate dark-green flakes of chlorite 0.05 to 0.2 inch also occur in the matrix. Metacrysts of reddish-brown garnet, 0.05 inch in diameter, are most abundant along contacts of the more micaceous beds.

Quartz-mica schist beds were cut at 40.9-41.8, 42.0-43.2, and 45.9-46.5 feet. These beds consist of quartz (50-60 percent), muscovite (20-30 percent), biotite (10-15 percent), and chlorite (trace to 
Feet

$60.9-70.3$

70.3-72.1

$70.3-70.5$

$70.5-72.1$

$70.5-71.3$

$71.3-72.1$

$72.1-72.8$

$72.8-74.0$

$74.0-81.0$

$81.0-163.4$

81.0-81.05

$81.05-87.5$

$87.5-89.0$

$89.0-128.0$
Hole 5-Continued

Description

Quartz-mica-chlorite schist-Continued

3 percent). Pseudomorphs after staurolite form less than 3 percent of the volume of quartz-mica schist.

Irregular discontinuous quartz stringers, as much as 1 inch thick, form about 5 percent of the core. Quartz-mica-tourmaline schist: The composition at 62 feet is quartz (55 percent), muscovite (25 percent), biotite ( 15 percent), and tourmaline ( 5 percent); at 70 feet the composition is quartz (45 percent), muscovite (30 percent), and tourmaline (25 percent). Muscovite increases to 45 percent and tourmaline decreases to 10 percent in a 1-inch layer at the pegmatite contact. Muscovite aggregates pseudomorphous after staurolite form about 1 percent of the rock. Black euhedral metacrysts of tourmaline are as much as 0.25 inch. Quartz stringers that reach a maximum of one-fourth inch in thickness form about 3 percent of the core.

Pegmatite.

Albite-quartz-muscovite pegmatite (zone 1, border zone): Contains albite (50 percent), quartz (35 percent), muscovite (12 percent), tourmaline ( 2 percent), and apatite (trace). Moderately iron stained. Average grain size is very fine $(0.15 \mathrm{inch})$. The grain size of the individual minerals varies widely. White to grayish, buff-stained, blocky to subplaty albite $\left(\mathrm{N}_{\alpha}{ }^{\prime}=1.531\right)$ grains are 0.05 to 0.3 inch; colorless to milky-white quartz grains are from less than 0.05 to 0.4 inch; yellowish-silvery muscovite from 0.05 to 0.25 inch; greenish-black to black euhedral tourmaline grains are as much as $0.3 \mathrm{inch}$; and rounded bluish-green apatite grains are less than 0.05 inch. Quartz-albite pegmatite (zone 2, wall zone):

Quartz-albite pegmatite: Contains quartz (85 percent), albite (12 percent), muscovite (2 percent), and beryl ( 0.12 percent of 0.75 foot of recovered core). Average grain size is 1 inch. One yellowish-white prismatic grain of beryl $\left(\mathrm{N}_{\omega}=1.586\right), 0.5$ by 0.1 inch, occurs at 71.1 feet.

Albite-quartz-muscovite pegmatite: Contains albite (63 percent), quartz (30 percent), muscovite $(6$ percent), apatite $(<0.5$ percent), and tourmaline (trace). Average grain size 0.4 inch.

Muscovite-quartz-tourmaline schist: Contains muscovite (45 percent), quartz (40 percent), tourmaline (15 percent), and apatite (trace). Black tourmaline metacrysts are as much as 0.4 inch in length, but a verage about 0.2 inch. A few quartz veinlets occur.

Albite-quartz-muscovite pegmatite (zone 2, wall zone): Contains albite (60 percent), quartz (30 percent), muscovite ( 8 percent), unidentified alteration products of phosphate minerals ( 2 percent), and apatite (trace). The average grain size is about 0.3 inch. About 35 percent of the pegmatite is sugary grained $(0.05 \mathrm{inch})$, in irregular aggregates as much as 3 inches, and the remainder of the pegmatite averages about 0.6 inch in grain size. The alteration products of phosphate minerals occur as grayish-brown to grayish-black stains, in 0.05 - to 0.1 -inch spots.

Muscovite-quartz-tourmaline schist: Similar to schist at 72.1-72.8 feet. The schist is cut by a few irregular quartz stringers, 0.25 to 1 inch thick. A few beds at 79-81 feet contain as much as 40 percent tourmaline.

Pegmatite.

Quartz-muscovite pegmatite (zone 1, border zone): Contains quartz (94 percent), muscovite (5 percent), albite $(<1$ percent), and apatite (trace). Very fine grained $(0.05$ inch). White to buff-stained albite $\left(\mathrm{N}_{\alpha}{ }^{\prime}=1.530\right)$ occurs only at 81.05 feet.

Albite-q uartz-pegmatite (zone 2, wall zone): Contains albite (60 percent), quartz (35 percent), muscovite (4 percent), and apatite (trace). Individual grains average 0.4 inch. Albite $\left(\mathrm{N}_{\alpha}{ }^{\prime}=\right.$ 1.530) occurs in white blocky to subplaty grains. The maximum size of recovered muscovite books is. 0.25 inch.

Cleavelandite-quartz-muscovite pegmatite (zone 3, first intermediate zone): Contains cleavelandite (58 percent), quartz (25 percent), muscovite (15 percent), tourmaline ( 1 percent), amblygonitemontebrasite $(<1$ percent), and apatite (trace). Average grain size is about 1.5 inches. The recovered muscovite books reach a maximum of 1.75 inches. Black tourmaline grains range in size from 0.05 to 0.75 inch. Grayish-white amblygonite-montebrasite occurs in a single grain, 0.4 by 2 inches at 88.9 feet; $\mathrm{N}_{\gamma}^{\prime}=1.62$. The amblygonite-montebrasite grain has a buff-white dusty coating and is bordered by fine-grained muscovite $(0.25$ inch).

Cleavelandite-quartz pegmatite (zone 5, third intermediate zone): Contains cleavelandite (55 percent), quartz (40 percent), muscovite (4 percent), amblygonite-montebrasite ( 0.5 percent), cassiterite ( $<0.5$ percent), tourmaline (trace), apatite (trace), and tantalite-columbite (trace). Individual grains average about 1.25 inches, but aggregates average 3 inches. Cleavelandite $\left(\mathrm{N}_{\alpha}{ }^{\prime}=1.528\right)$ occurs in aggregates as large as 3 feet. The maximum size of muscovite is 1.5 inches. Ten irregular to elongate subhedral grayish-white grains of amblygonite-montebrasite, 
Feet

$128.0-136.0$

$136.0-141.0$

141.0-150.9

150.9-163.2

163.2-163.4

$163.4-163.8$

163.8-165.1

165.1-166.2

166.2-169.8
Hole 5-Continued

Description

Pegmatite-Continued

0.5 to 2.5 inches in length, were cut between 101.0 and 106.0 feet; $\mathrm{N}_{\gamma}{ }^{\prime}=1.62$. Brownish-black irregular to subhedral grains of cassiterite range in diameter from less than 0.05 to 0.25 inch; cassiterite is most abundant at the contact of muscovite and cleavelandite; a few grains of cassiterite are included in cleavelandite, amblygonite-montebrasite, muscovite, and quartz. One grain of tantalite-columbite, 0.05 by 0.01 inch, was noted.

Cleavelandite-quartz-muscovite pegmatite (zone 3, first intermediate zone): Contains cleavelandite (58 percent), quartz (30 percent), muscovite (7 percent), beryl (3.17 percent of 4.0 feet of recovered core), amblygonite-montebrasite (1 percent), cassiterite $(<0.5$ percent), and apatite (trace). Average grain size is about 1.75 inches. The largest muscovite book recovered is 1.25 inches; numerous small flakes of muscovite in the rubble indicate that a considerable amount of muscovite was carried into the sludge. Two white anhedral masses of beryl $\left(\mathrm{N}_{\omega}=1.582\right.$ to 1.583$)$ are 1.75 and 2 inches in maximum dimension. The beryl has ground edges, indicating loss of beryl in the sludge. Amblygonite-montebrasite occurs in one grayish-white irregular grain, 1 by 2 inches, at 133.2 feet; $\mathrm{N}_{\gamma}{ }^{\prime}=1.62$. Fine muscovite $(0.2 \mathrm{inch})$ rims the amblygonite-montebrasite grain. Brownish-black, rounded to irregular grains of cassiterite are 0.05 to 0.1 inch in diameter.

Cleavelandite-quartz pegmatite (zone 5 , third intermediate zone): Contains cleavelandite $(50$ percent), quartz ( 45 percent), muscovite ( 4 percent), tourmaline ( 0.5 percent), cassiterite $(<0.5$ percent), and apatite (trace). Average grain size is about 1.5 inches. The maximum size of muscovite is 1.75 inches. Brownish-black grains of cassiterite range in size from 0.05 to 0.2 inch. Greenish- to bluish-black tourmaline grains average about 0.15 inch in length.

Quartz-cleavelandite-muscovite pegmatite (zone 3, first intermediate zone): Contains quartz (39 percent), cleavelandite ( 30 percent), muscovite ( 25 percent), beryl (5.06 percent of 3.1 feet of recovered core), apatite (trace), and tourmaline (trace). Individual grains average about 1 inch. Cleavelandite $\left(\mathrm{N}_{\alpha}{ }^{\prime}=1.528\right)$ occurs in aggregates as large as 4 inches. The maximum size of muscovite is 2.25 inches. A 2.5-inch-long anhedral beryl grain at 144 feet is milky white showing a faint greenish tint. The outer edge of the beryl grain $\left(\mathrm{N}_{\omega}=1.583\right)$ is complexly intergrown with quartz, cleavelandite, and muscovite; the center of the grain has $\mathrm{N}_{\omega}=1.580$. A 0.05 -inch fracture cutting across the beryl is filled with fine-grained muscovite.

Albite-quartz-muscovite pegmatite (zone 2, wall zone): Contains albite (48 percent), quartz (34 percent), muscovite (10 percent), perthite ( 3 percent), tourmaline ( 3 percent), unidentified alteration products of phosphate minerals ( 1 percent), beryl $(0.12$ percent of 11.4 feet of recovered core), apatite (trace), tantalite-columbite (trace), and an unidentified soft greenish-gray mineral (trace). Average grain size is about $0.8 \mathrm{inch}$. This unit can be subdivided into layers on the basis of mineralogy and grain size (see table at end of $\log$ ).

Albite is blocky, platy, and sugary-grained. The sugary-grained albite occurs with quartz in aggregates as much as 3 inches across. Coarse platy albite occurs in aggregates averaging 2 inches in diameter. Flesh-colored blocky perthite, 0.25 to 2.25 inches in diameter, is embayed and veined by albite, quartz, and muscovite. The muscovite averages 0.6 inch, and reaches a maximum of 2.5 inches. Two white to irregularly translucent, slightly milky white elongate grains of beryl $\left(\mathrm{N}_{\omega}=1.581\right)$ occur at $151.6-151.7 \mathrm{feet}$; the dimensions of the grains are 1.25 by 0.5 inches and 1.25 by 0.25 inches. Bluish-green apatite grains, 0.05 to 0.1 inch, occur in aggregates as large as 0.5 inch. A rounded greenish-gray, soft mineral, 0.2 inch, occurring in traces may be aggregates of very fine grained lithia mica. Grayish-brown to black unidentified alter?tion products of phosphate minerals stain the core. Bluish-black euhedral grains of tourmaline average about 0.2 inch in length. Three plates of tantalite-columbite are 0.05 inch long and less than 0.01 inch thick.

Albite-quartz-muscovite pegmatite (zone 1, border zone): Contains albite (45 percent), quartz (40 percent), muscovite (12 percent), garnet ( 2 percent), apatite (trace), and tourmaline (trace). Average grain size is about 0.2 inch. Albite at 163.3 feet has $\mathrm{N}_{\alpha^{\prime}}=1.530$. Reddish-brown grains of garnet range in size from less than 0.05 to 0.25 inch.

Quartz-muscovite-tourmaline schist: Contains quartz (40 percent), muscovite (40 percent), tourmaline (18 percent), and garnet (2 percent). Black euhedral tourmaline grains range in length from 0.05 to 0.4 inch.

Quartz-mica schist: Contains quartz (50 percent), muscovite (30 percent), and biotite (20 percent).

Traces of tourmaline occur at 164 feet. A few quartz lenses are 0.05 to 0.5 inch thick.

Quartz vein: Colorless to grayish-milky quartz.

Quartz-mica schist: Similar to schist at 163.8-165.1 feet. 
Feet

$169.8-238.2$

169.8-170.2

$170.2-177.0$

$177.0-177.2$

$177.2-177.7$

177.7-180.0

180.0-186.6

186.6-200.1
Hole 5-Continued

Description

Pegmatite.

Quartz-muscovite pegmatite (zone 1, border zone): Contains quartz (70 percent), muscovite (25 percent), albite ( 4 percent), and apatite $(0.5$ percent). Very fine grained $(0.15$ inch). A layer of colorless massive quartz, 0.1 inch thick, separates the border zone and the schist. Albite $\left(\mathrm{N}_{\alpha}{ }^{\prime}=1.530\right)$ occurs only at 170.2 feet.

Albite-quartz-perthite pegmatite (zone 2, wall zone): Contains albite (50 percent), quartz (25 percent), perthite ( 15 percent), muscovite ( 7 percent), beryl (1.55 percent of 6.5 feet of recovered core), unidentified phosphate minerals and their alteration products ( 1 percent), tourmaline $(<0.5$ percent), apatite $(<0.5$ percent), and tantalite-columbite (trace). Average grain size is about 0.6 inch. The zone can be subdivided into layers on the basis of mineralogy and grain size (see table at end of $\log$ ).

Albite occurs chiefly as blocky to platy grains. Aggregates of sugary-grained albite containing 10 percent quartz are as much as 3 inches across. Flesh-colored perthite crystals 1 to 3.5 inches in diameter, are corroded and veined by albite, quartz, and muscovite. Tantalite-columbite occurs as two platy grains, 0.01 by 0.05 inch and 0.01 by 0.25 inch. Five grains of beryl are exposed in this segment of wall zone and are described in the table at end of log.

Quartz-muscovite-albite pegmatite (zone 1, border zone): Contains quartz (45 percent), muscovite (33 percent), albite (20 percent), garnet (1.5 percent), unidentified alteration products of phosphate minerals ( 0.5 percent), tourmaline (trace), and apatite (trace). Average grain size is about 0.1 inch. White to buff-stained subplaty albite has $\mathrm{N}_{\alpha}^{\prime}=1.531$. Reddish-brown garnet occurs with muscovite and quartz in an irregular aggregate, 1.5 inches in diameter. A blue grain of tourmaline, 0.25 by $0.1 \mathrm{inch}$, is adjacent to the garnet aggregate.

Quartz-albite pegmatite (zone 2, wall zone): Contains quartz (65 percent), albite (30 percent), muscovite (2 percent), beryl ( 1.80 percent of 0.5 foot of recovered core), unidentified phosphate minerals and their alteration products (1 percent), apatite (trace), and tantalite-columbite (trace). Quartz grains and aggregates of platy albite average 1 inch. A white irregularly stained subhedral grain of beryl $\left(\mathrm{N}_{\omega}=1.584\right)$ at 177.5 feet is 0.9 by 0.5 inch. Several rounded dark-green to brown grains, 0.05 to 0.5 inch, are probably altered phosphate minerals of the lithiophilitetriphylite group.

Quartz-muscovite-albite pegmatite (zone 1, border zone): Similar to pegmatite at 177.0-177.2 feet. Albite-perthite-quartz pegmatite (zone 2, wall zone): Contains albite (36 percent), perthite (30 percent), quartz (25 percent), muscovite (6 percent), unidentified alteration products of phosphate minerals ( 1.5 percent), garnet ( 0.5 percent), tourmaline ( 0.5 percent), apatite (trace), tantalitecolumbite (trace), and cassiterite (trace). Average grain size is about 0.9 inch. The zone can be subdivided into layers on the basis of mineralogy (see table at end of log). Blocky to platy albite occurs as grains that average $0.5 \mathrm{inch}$, but are in aggregates as large as 4 inches. Sugarygrained albite $\left(\mathrm{N}_{\alpha}^{\prime}=1.531\right)$ occurs as aggregates, averaging 1.5 inches across, that contain 25 percent quartz. Pink to reddish garnet occurs in aggregates as much as 0.75 inch in diameter (average 0.3 inch) that are most abundant at $\mathbf{1 8 0 . 7}$ feet. Bluish tourmaline rims some of the garnet. Bluish-black tourmaline $(0.25 \mathrm{inch})$, brownish-black cassiterite $(0.2 \mathrm{inch})$, and greenish apatite (0.05 inch) occur in traces. Much of the rock is stained by grayish-buff to brownish-black alteration products of phosphate minerals.

Quartz-cleavelandite-muscovite pegmatite (zone 3, first intermediate zone) : Contains quartz (40 percent), cleavelandite ( 36 percent), muscovite ( 17 percent), beryl (5.60 percent of 11.2 feet of recovered core), tourmaline ( 0.5 percent), unidentified phosphate minerals and their alteration products ( $<0.5$ percent), perthite (trace), apatite (trace), cassiterite (trace), and loellingite(?) (trace). Average grain size is about 2 inches. The maximum size of muscovite books is 8 inches.

Three grains of beryl are exposed in this segment of zone 3 and are described in the table at end of log. Several 0.5-inch perthite grains occur at 186.7 feet. Eight grains of cassiterite, 0.1 to 0.25 inch in diameter, occur as inclusions in beryl and cleavelandite at 199.0-199.5 feet. Phosphate minerals occur as rounded to irregular dark-colored grains, 0.1 to 1 inch in diameter; their alteration products stain other minerals. Bluish-black and black euhedral grains of tourmaline average 0.3 inch in length; they commonly occur as inclusions in muscovite. 
Feet

200.1-207.2

$207.2-217.0$

$217.0-231.6$

$231.6-235.1$

$235.10-238.15$

$238.15-238.20$

Pegmatite-Continued

Hole 5-Continued

Description

Cleavelandite-muscovite pegmatite (zone 5, third intermediate zone): Contains cleavelandite (84 percent), muscovite ( 9 percent), quartz (4 percent), beryl $(2.58$ percent of 7.0 feet of recovered core), cassiterite $(<0.5$ percent), apatite (trace), and tourmaline (trace). Average grain size is about 1 inch. An aggregate from 200.1 to 206.4 feet consists chiefly of plates of cleavelandite $\left(\mathrm{N}_{\alpha}{ }^{\prime}=1.528\right)$ averaging 1.25 inches in length; other minerals arē muscovite (5 percent), quärtz (3 percent), cassiterite $(<0.5$ percent), apatite (trace), and tourmaline (trace). Pegmatite from 206.4 to 207.2 feet consists of muscovite (40 percent), beryl (25.80 percent of 0.7 foot of recovered core), cleavelandite (24 percent), and quartz (10 percent). Individual grains average 1 inch. Muscovite books range. in size from 0.05 to $0.5 \mathrm{inch}$, averaging $0.3 \mathrm{inch}$. Three grains of beryl are exposed in this segment of zone 5 and are described in table at end of log.

Quartz pegmatite (zone $6 \mathrm{~b}$, fourth intermediate zone): Consists entirely of colorless to slightly milky white, massive quartz.

Cleavelandite-quartz pegmatite (zone 5 , third intermediate zone): Contains cleavelandite (51 percent), quartz (45 percent), muscovite (3 percent), apatite (trace), and cassiterite (trace). Individual grains average about 1.25 inches. Cleavelandite aggregates are as large as 15 inches. The maximum size of muscovite books is 2.5 inches. One grain of cassiterite, less than 0.1 inch in diameter, is included in cleavelandite.

Perthite-cleavelandite-quartz pegmatite (zone 4, second intermediate zone): Contains perthite (65 percent), cleavelandite (20 percent), quartz (10 percent), muscovite (4 percent), and apatite (trace). Average grain size is 4 inches. Two flesh-colored grains of perthite are 15 and 3 inches in length; the edges of the grains are embayed by quartz, cleavelandite, and muscovite. The maximum size of musoovite is 1 inch.

Quartz-cleavelandite-museovite pegmatite (zone 3, first intermediäte zone): Contains quartz (59 percent), cleavelandite (20 percent), muscovite (20 percent), beryl (0.47 percent of 2.25 feet of recovered core), tourmaline $(<0.5$ percent), and apatite (trace). Average grain size decreàses from 2 inches at 235.1 feet to about 0.7 inch at 237 feet. Cleavelandite has $\mathrm{N}_{\alpha}{ }^{\prime}=1.530$. The maximum size of muscevite is 2 inches. Three buff-stained white euhedral grains of beryl $\left(\mathrm{N}_{\alpha}=\right.$ 1.580) at 237.4 feet are $0.35,0.7$, and 1.25 inches in maximum exposed dimensions. Black euhedra: grains of tourmaline, associated with muscovite, average about $0.5 \mathrm{inch}$ in length and $0.1 \mathrm{ineh}$ in diameter.

Quartz-muscovite pegmatite (zone 1, border zone): Contains quartz (78 percent), muscovite (20 percent), tourmaline (1 percent), and apatite (trace). Very fine grained $(0.15 \mathrm{inch})$. A layer of massive quartz, 0.1 to 0.5 inch thick, is immediately adjacent to the schist contact.

$238.2-243.6$

Quartz-mica schist: Similar to schist at 163.8-165.1 feet. Traces of tourmaline occur at 238.2-238.5 feet.

$243.6-244.6$

$244.6-256.6$

Quartz vein: Colorless to slightiy milky white massive quartz. Contains irregular fragments of schist. Mica flakes and chlorite flakes are as much as 0.25 inch.

Quartz-mica-chlorite schist: Similar to schist at 15.0-40.9 feet. Irregular quartz stringers, 0.05 to 0.75 inch in thickness, form 5 percent of the rock. 
Hole 5-Continued

Angles of intersection of drill core in hole 5 with bedding, schistosity, pegmatite contacts, quartz vein contacts, and fractures, in degrees

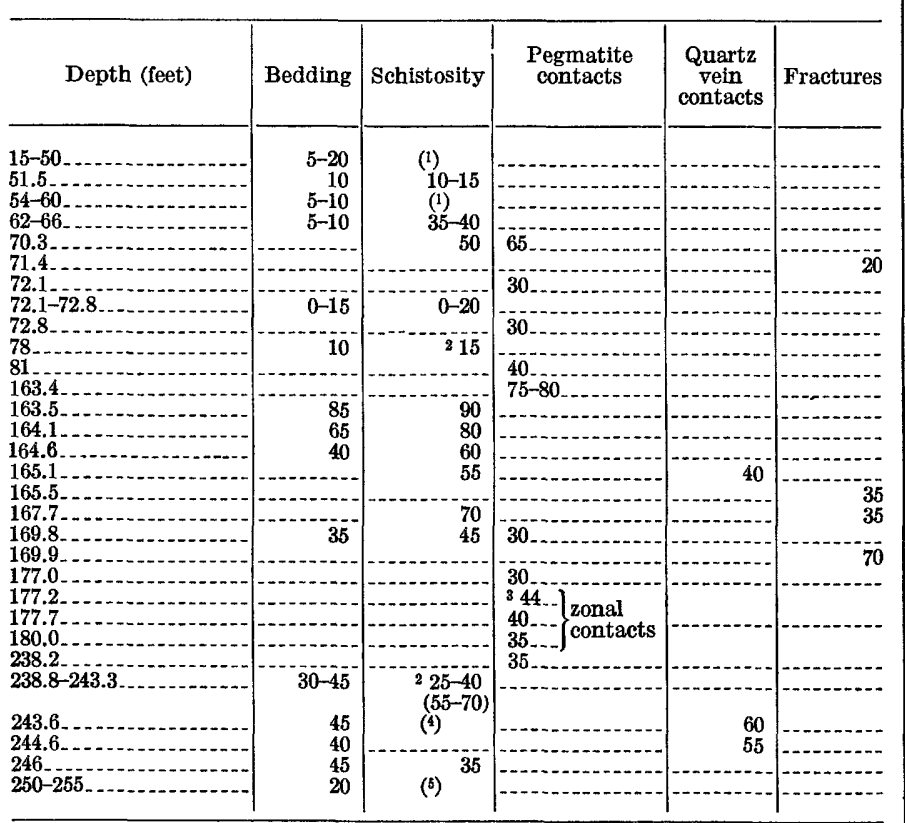

1 Parallel to beds.

2 Intersects bedding at $25^{\circ}$.

Zonal contacts.

- Approximately parallel to beds.
Mineralogic composition of layers in zone 2 (wall zone) at 150.9-163.2, 170.2-177.0, and 180.0-186.6 feet, hole 5

\begin{tabular}{|c|c|c|c|c|c|c|c|}
\hline \multirow{2}{*}{$\begin{array}{l}\text { Depth (feet) of zone } \\
\text { and layers within } \\
\text { zone }\end{array}$} & \multirow{2}{*}{$\begin{array}{l}\text { Average } \\
\text { grain } \\
\text { size } \\
\text { (inches) }\end{array}$} & \multicolumn{6}{|c|}{ Principal minerals (estimated percent) } \\
\hline & & $\begin{array}{l}\text { Blocky } \\
\text { to platy } \\
\text { albite }\end{array}$ & $\begin{array}{l}\text { Sugary- } \\
\text { grained } \\
\text { albite }\end{array}$ & Quartz & $\begin{array}{l}\text { Mus- } \\
\text { covite }\end{array}$ & $\begin{array}{c}\text { Perth- } \\
\text { ite }\end{array}$ & $\begin{array}{c}\text { Other } \\
\text { principal } \\
\text { minerals }\end{array}$ \\
\hline $\begin{array}{r}150.9-163.2: \\
150.9-155.7\end{array}$ & $10.05-0.1$ & 40 & 15 & 30 & 5 & & 76 \\
\hline $\begin{array}{l}155.7-157.3 \\
157.3-163.2\end{array}$ & $\begin{array}{r}1.0 \\
.5\end{array}$ & $\begin{array}{l}30 \\
45\end{array}$ & $\begin{array}{l}3 \\
5\end{array}$ & $\begin{array}{l}30 \\
35\end{array}$ & $\begin{array}{l}10 \\
12\end{array}$ & 825 & - \\
\hline $\begin{array}{c}170.2-177.0: \\
170.2-173.4 \ldots\end{array}$ & ${ }_{2}^{1}, 05$ & 55 & 14 & 25 & 5 & & \\
\hline 173.4-176.2_. & 1.05 & 25 & 12 & 20 & 6 & 435 & 更 \\
\hline $\begin{array}{l}176.2-177.0 \\
180.0-186.6\end{array}$ & .7 & 45 & & 35 & 4 & & ${ }^{8} 11.6$ \\
\hline $180.0-180.7$ & ${ }^{1} .03$ & 15 & 45 & 30 & 2 & & $-\cdots$ \\
\hline $180.7-184.5$ & 1.05 & 15 & 10 & 25 & 4 & $\$ 45$ & \\
\hline $184.5-186.6$ & $\begin{array}{l}1.05 \\
2.6\end{array}$ & 25 & 20 & 30 & 9 & e 15 & \\
\hline
\end{tabular}

1 Sugary-grained phase.

2 Fine-grained phase.

3 Perthite occurs in grains, 0.25 to 2.25 inches in diameter.

4 Perthite occurs in grains, 1 to 3.5 inches in diameter.

5 Perthite occurs in grains 6 inches in diameter.

6 Maximum size of grains of perthite is 1.5 inches.

7 Tourmaline.

8 Beryl.

Description of beryl crystals in zone 2 (at 170.2-177.0 feet), zone 3 (at 186.6-200.1 feet), and zone 5 (at 200.1-207.2 feet), hole 5

\begin{tabular}{|c|c|c|c|c|c|}
\hline $\begin{array}{c}\text { Zone depth } \\
\text { (feet) }\end{array}$ & $\begin{array}{c}\text { Depth of } \\
\text { beryl } \\
\text { crystal } \\
\text { (feet) }\end{array}$ & $\begin{array}{c}\text { Dimensions } \\
\text { (inches) }\end{array}$ & Shape & Color & $\mathbf{N \omega}$ \\
\hline \multirow[t]{2}{*}{$\begin{array}{l}2 \text { (wall zone), } \\
170.2-177.0 .\end{array}$} & $\begin{array}{l}175.5 \\
175.9\end{array}$ & $\begin{array}{l}10.2 \text { by } 0.7 \\
\text { (2) }\end{array}$ & $\begin{array}{l}\text { Subhedral. } \\
\text { Rounded, }\end{array}$ & White & $\begin{array}{l}1.585 \\
1.583\end{array}$ \\
\hline & $\begin{array}{l}176.0 \\
176.9 \\
189.1\end{array}$ & $\begin{array}{c}{ }^{(3)} \\
1.75 \text { by } 2.0 \\
1.75 \text { by } 2.5\end{array}$ & Subhedral. & \begin{tabular}{|c} 
do \\
Pale yellow-
\end{tabular} & $\begin{array}{l}1.584 \\
1.585 \\
1.581\end{array}$ \\
\hline \multirow[t]{2}{*}{$\begin{array}{l}3 \text { (first inter- } \\
\text { mediate } \\
\text { zone), } \\
\text { 186.6-200.1 }\end{array}$} & & 1.75 oy 2.0 & & $\begin{array}{l}\text { ish white to } \\
\text { greenish } \\
\text { white. }\end{array}$ & \\
\hline & $\left|\begin{array}{|}199.0-199.3 \\
199.3-200.0\end{array}\right|$ & (4) & Anhedral & White....... & $\left\{\begin{array}{r}1.583-1.584 \\
1.582\end{array}\right.$ \\
\hline 5 (third inter- & 206. 5-206.8 & 1.0 by 3.5 & Rounded, & -...do... & $1.584-1.587$ \\
\hline $\begin{array}{l}\text { zone), } \\
200.1-207.2\end{array}$ & $\begin{array}{l}207.0 \\
207.1\end{array}$ & $\begin{array}{r}.5 \text { by } 1.0 \\
1.75 \text { by } 1.75\end{array}$ & $\begin{array}{l}\text { Irregular } \\
\text { Subhedrai. }\end{array}$ & _. do & $\begin{array}{l}1.586 \\
1.586\end{array}$ \\
\hline
\end{tabular}

1 Two grains, each of the same dimensions.

2 Area, 0.07 square inch.

4 Total area of seven irregular masses intergrown with cleavelandite is 32.37 square inches.

Range of four determinations. 


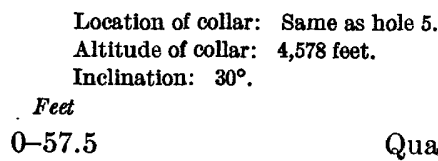

57.5-90.5

57.5-57.6

$57.6-61.5$

61.5-78.6

78.6-86.5

$86.5-90.5$

$90.5-100.0$

100.0-121.6 $100.0-105.5$
Hole 6

Bearing: N. $6312^{\circ} \mathrm{E}$.

Length: 154.2 feet.

Description

Quartz-mica-chlorite schist: Brownish-gray, interbedded with lighter gray quartz-mica schist and micaceous quartzite. The quartz-mica-chlorite schist contains quartz (45-50 percent), muscovite (25-30 percent), biotite (10-20 percent), chlorite ( $3-5$ percent), and garnet ( 0.5 percent). Pseudomorphs after staurolite are 0.2 to 1.5 inches long; they form as much as 5 percent of individual beds, but average about 3 percent. Isolated elongate dark-green flakes of chlorite, 0.05 to 0.2 inch, occur in the schist matrix. Metacrysts of reddish-brown garnet (average 0.05 inch in diameter) are especially abundant along the contacts of quartz-mica-chlorite schist with beds of quartzite and of quartz-mica schist.

Interbeds of quartz-mica schist at 6.5-17.0, 32.0-35.0, and 50.5-57.5 feet consist of quartz (55-65 percent), muscovite (10-25 percent), biotite ( $5-15$ percent), and garnet $(<0.5$ percent).

Quartzite beds at $24.0-30.0$ and $30.5-32.0$ feet contain quartz (75-85 percent), muscovite and biotite (15-25 percent).

Quartz veinlets, 0.05 to 5 inches thick, constitute about 5 percent of the core. Pegmatite.

Quartz-muscovite-tourmaline pegmatite (zone 1, border zone): Contains quartz (77 percent), muscovite (15 percent), tourmaline ( 5 percent), albite ( 2 percent), and apatite ( 0.5 percent). Very fine grained (average $0.15 \mathrm{inch}$ ). Bluish-black grains of tourmaline range in size from 0.05 to 0.3 inch. Iron-stained albite $\left(\mathrm{N}_{\alpha}^{\prime}=1.531\right)$ occurs in 0.2 -inch aggregates.

Albite-quartz-muscovite pegmatite (zone 2, wall zone): Contains albite (55 percent), quartz (30 percent), muscovite (10 percent), tourmaline ( 4 percent), unidentified alteration products of phosphate minerals ( $<0.5$ percent), and apatite $(<0.5$ percent). The average grain size of most of this unit is about 0.5 inch, but from 58.5 to 61.5 feet about 20 percent is very fine grained (average $0.05 \mathrm{inch}$ ) sugary-grained albite $\left(\mathrm{N}_{\alpha}{ }^{\prime}=1.529\right)$ and quartz, in irregular aggregates as much as 2 inches. White subplaty albite $\left(\mathrm{N}_{\alpha^{\prime}}\right.$ slightly more than 1.529) occurs in aggregates as large as 3 inches. The average size of muscovite books increases from 0.25 inch at 58 feet to 0.75 inch at 61.5 feet. Bluish-black euhedral grains of tourmaline, 0.05 to 0.5 inch, occur in aggregates as much as 1.5 inches; these aggregates are concentrated at 60.5 to 61.5 feet. Rounded brown claylike aggregates, 0.05 to 0.25 inch, at $58.5-61.5$ feet, are probably altered phosphate minerals; brownish-to grayish-brown alteration products of phosphate minerals stain the other minerals in the core.

Cleavelandite-quartz pegmatite (zone 5, third intermediate zone): Contains cleavelandite ( 57 percent), quartz ( 40 percent), muscovite $(2$ percent), tourmaline $(0.5$ percent), apatite $(<0.5$ percent), cassiterite (trace), and tantalite-columbite (trace). Individual grains average about 1.25 inches, but aggregates average 6 inches. White cleavelandite $\left(\mathrm{N}_{a}^{\prime}=1.528\right)$ occurs in aggregates as large as 4 feet. The maximum size of muscovite books is 0.75 inch. Euhedral bluish-black grains of tourmaline $\left(\mathrm{N}_{\omega}=1.66\right)$ average about 0.25 inch in length. Rounded to elongate bluish-green grains of apatite average about 0.05 inch in diameter. Four euhedral brownish-black grains of cassiterite, 0.05 to 0.2 inch, occur from 75.4 to 78.6 feet. Two grains of tantalite-columbite are 0.15 by 0.5 inch and 0.01 by 0.2 inch.

Quartz-cleavelandite-muscovite pegmatite (zone 3, first intermediate zone): Contains quartz (75 percent), cleavelandite (13 percent), muscovite (11 percent), tourmaline (trace), and apatite (trace). Average grain size is about 1.5 inches. Muscovite books reach a maximum of 2 inches.

Albite-quartz-muscovite pegmatite (zone 2, wall zone): Contains albite (64 percent), quartz (30 percent), muscovite ( 5 percent), tourmaline ( 1 percent), tantalite-columbite (trace), and apatite (trace). Average grain size is 0.5 inch. White blocky to subplaty albite $\left(\mathrm{N}_{\alpha}^{\prime}=1.529\right)$ occurs in aggregates as much as 3.5 inches. The maximum size of muscovite books is 0.75 inch. Euhedral to subhedral bluish-black grains of tourmaline, averaging about 0.15 inch, occur in aggregates as large as 0.5 inch. One blade of tantalite-columbite is 0.65 inch long and 0.01 inch thick.

Quartz-mica schist: Consists of quartz (55 percent), muscovite (25-30 percent), biotite (15-20 percent), and accessory garnet. Quartz stringers, as much as 0.2 inch thick, form about 2 percent of the core. Pegmatite.

Albite-quartz-muscovite pegmatite (zone 2, wall zone): Contains albite (50 percent), quartz (40 percent), muscovite ( 8 percent), tourmaline ( 1 percent), beryl $(0.31$ percent of 5.3 feet of recovered core), garnet ( $<1$ percent), and apatite (trace). The average grain size increases from 0.4 inch at 100.5 feet to 1 inch at 105.0 feet. White subplaty albite $\left(\mathrm{N}_{\alpha}^{\prime}=1.530\right)$ occurs in aggregates as large as 3.5 inches. Muscovite reaches a maximum of 0.9 inch. Bluish-black grains of tourmaline, as much as 0.25 inch long, occur in aggregates as large as 1.5 inches. Reddish rounded grains of garnet are as much as 0.25 inch in diameter. Five beryl grains are exposed in this segment of wall zone and are described in table at end of $\log$. 
Feet

$105.5-115.5$

115.5-121.4

121.4-121.6

$121.6-121.7$

$121.7-154.2$
Hole 6-Continued

Description

Pegmatite-Continued

Cleavelandite-quartz-muscovite pegmatite (zone 3, first intermediate zone): Contains cleavelandite (48 percent), quartz (40 percent), muscovite (10 percent), tourmaline ( $<1$ percent), amblygonitemontebrasite ( $<1$ percent), tantalite-columbite $(<0.5$ percent), apatite (trace), vivianite(?) (trace), loellingite(?) (trace), and unidentified buff-white to greenish-brown phosphate minerals(trace). Individual grains average $0.75 \mathrm{inch}$, and aggregates are about $1.75 \mathrm{inch}$. Cleavelandite $\left(\mathrm{N}_{\alpha}{ }^{\prime}=\right.$ 1.528) occurs in aggregates as large as 4 inches. Muscovite and quartz grains have maximum dimensions of 2 to 3 inches. Black to greenish-black euhedral grains of tourmaline average about 0.75 inch, but aggregates are as large as 2.25 inches. Amblygonite-montebrasite occurs in one white irregular grain, 2 inches long and 0.8 inch wide, at 115.4 feet; $\mathrm{N}_{\gamma}{ }^{\prime}=1.62$. Fine-grained muscovite ( 0.2 inch) occurs along the grain boundaries of the amblygonite-montebrasite crystal. Loellingite(?) occurs as silvery-gray irregular grains, 0.05 to 0.3 inch in diameter, at 112.8-113.7 feet. Irregular bluish grains of vivianite(?) commonly border the loellingite(?) grains; $\mathrm{N}_{\gamma}=1.65$; $\mathrm{N}_{\alpha}=1.610$; pleochroic from deep blue to faint yellow. Also at 112.8-113.7 feet, irregular buffwhite to greenish-to dark-brown rounded grains, 0.1 to 0.75 inch, are probably partly altered phosphate minerals. Eight grains of tantalite-columbite, as much as 0.3 inch long, are associated with muscovite and cleavelandite at 111.1-111.4 feet.

Albite-quartz-muscovite pegmatite (zone 2, wall zone): Contains albite (60 percent), quartz (30 percent), muscovite ( 7 percent), unidentified altered phosphate minerals and their alteration products (1.5 percent), tourmaline (1 percent), apatite (trace), and tantalite-columbite (trace). The grain size varies widely but averages about 0.4 inch. About 15 percent of the unit is very fine grained $(<0.1 \mathrm{inch})$. Albite decreases and quartz increases in amount from 120.5 feet to the contact with border zone at 121.4 feet. Albite at 121.2 feet has $\mathrm{N}_{\alpha}{ }^{\prime}=1.530$. The maximum size of muscovite is 1 inch. Buff-white to brown, rounded irregular grains, 0.05 to $0.3 \mathrm{inch}$, are probably altered phosphate minerals. Euhedral to subhedral, bluish-black grains of tourmaline are 0.05 to 0.4 inch. Two grains of tantalite-columbite are 0.05 and 0.15 inch long and 0.01 inch thick.

Quartz-muscovite pegmatite (zone 1, border zone): Contains quartz (79 percent), muscovite (20 percent), apatite ( 1 percent), and tourmaline (trace). Average grain size is 0.1 inch. Green to bluish-green grains of apatite are 0.01 to 0.1 inch in diameter.

Muscovite-quartz-tourmaline schist: Contains muscovite (50 percent), quartz (40 percent), and tourmaline (10 percent). Black to brownish-black tourmaline grains average about 0.02 inch in diameter and 0.15 inch in length.

Quartz-mica schist: Contains quartz (45-65 percent), muscovite (20-35 percent), biotite (10-20 percent), chlorite (trace to 3 percent), garnet (trace to 1 percent), staurolite (trace), and tourmaline (trace). Pseudomorphs of muscovite and biotite after euhedral staurolite, ranging from less than 0.1 to 1.5 inch in length, form as much as 10 percent of individual thin micaceous beds, but are completely absent in more quartzose beds; the content of these pseudomorphs in the schist averages 3 percent. Traces of brown staurolite occur in some of the pseudomorphs. Red grains of garnet average 0.05 inch in diameter. Black grains of tourmaline, less than 0.05 inch long, occur at 121.7 to 121.9 feet. Quartz stringers, 0.05 to 0.75 inch thick, form about 3 percent of the core; traces of yellow sulfide minerals (chalcopyrite and pyrite) occur in and adjacent to some of the quartz stringers.
Angles of intersection of drill core in hole 6 with bedding, schistosity, and pegmatite contacts, in degrees

\begin{tabular}{|c|c|c|c|}
\hline Depth (feet) & Bedding & Schistosity & $\begin{array}{c}\text { Pegmatite } \\
\text { contacts }\end{array}$ \\
\hline $\begin{array}{l}20 \\
40-52.5 \\
57.5 \\
94-97 \\
121.6\end{array}$ & $\begin{array}{r}10 \\
5-15 \\
5 \\
20 \\
30 \\
30 \\
30 \\
10 \\
0 \\
10 \\
5-15\end{array}$ & 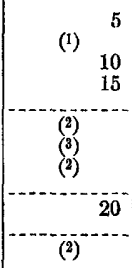 & 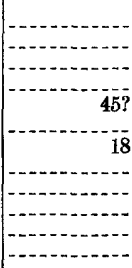 \\
\hline
\end{tabular}

Description of beryl crystals in zone 2 (wall zone), 100.0-105.5 feet, hole 6

\begin{tabular}{|c|c|c|c|c|}
\hline $\begin{array}{l}\text { Depth } \\
\text { (feet) }\end{array}$ & $\begin{array}{c}\text { Size } \\
\text { (inches) }\end{array}$ & Shape & Color & $N_{\omega}$ \\
\hline $\begin{array}{l}104.9 \\
104.9 \\
105.0 \\
105.0\end{array}$ & $\begin{array}{r}0.15 \\
.3 \\
1.05 \\
1.04\end{array}$ & \begin{tabular}{|c|} 
Euhedral $\ldots$. \\
- do
\end{tabular} & \begin{tabular}{|c} 
Pale-greenish white \\
do
\end{tabular} & $\begin{array}{l}1.580 \\
1.580 \\
1.581 \\
1.580\end{array}$ \\
\hline 105.3 & .5 by 2.5 & Rounded .......... & ...... do.... & 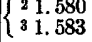 \\
\hline
\end{tabular}

1 Square inch.

2 Center.
3 At one end. 
Location of collar: Same as holes 5 and 6. Altitude of collar: 4,579 feet. Inclination: Minus $15^{\circ}$

Feet

0-38.0

$38.0-45.0$

$45.0-62.0$

62.0-120.2

62.0-62.4

$62.4-69.2$

69.2-70.8

70.8-108.0

$108.0-113.0$

$113.0-120.0$

$120.0-120.2$
No core.

Hole 7

Bearing: N. $6312^{\circ} \mathbf{E}$.

Length: 155.8 feet.

Description

Quartz-mica-chlorite schist: Contains quartz (45 percent), muscovite (20-30 percent), biotite (20-25 percent), chlorite ( 5 percent), and garnet $(0.5$ percent). Pseudomorphs of muscovite and biotite after staurolite, 0.1 to 0.3 inch in diameter, constitute 2 percent of the core. Elongate dark-green flakes of chlorite range from 0.05 to 0.15 inch. Reddish-brown metacrysts of garnet, 0.05 inch in diameter, are irregularly distributed in the schist. Quartz stringers, 0.05 to 1 inch thick, form about 8 percent of the core.

Quartz-mica schist: Contains quartz (55-60 percent), muscovite (20-25 percent), biotite (15 percent), and chlorite (1-3 percent). Quartz stringers, 0.05 to 0.75 inch thick, form about 5 percent of the core. Pegmatite.

Quartz-muscovite pegmatite (zone 1, border zone): Contains quartz (78 percent), muscovite (20 percent), beryl $(0.5 \text { percent) })^{1}$, tourmaline $(0.5$ percent), and apatite $(<0.5$ percent). Very fine grained (average $0.2 \mathrm{inch}$ ). Two subhedral white grains of beryl $\left(\mathrm{N}_{\omega}=1.581\right)$ are 0.1 by 0.5 inch and 0.1 by 0.25 inch.

Albite-quartz-muscovite pegmatite (zone 2, wall zone): Contains albite ( 52 percent), quartz (35 percent), muscovite ( 8 percent), tourmaline ( 3 percent), unknown alteration products of phosphate minerals (0.5-1 percent), garnet (trace), and apatite (trace). Individual grains average about 0.5 inch, but aggregates of grains are commonly 1 inch. About 15 percent of the albite is very fine grained ( 0.05 inch), occurring in sugary-grained aggregates, 0.5 to 3 inches. Aggregates of blocky to subplaty albite are as large as 3 inches in diameter. The muscovite books reach a maximum of 1 inch. Bluish-black euhedral tourmaline grains average about 0.4 inch in length.

Cleavelandite-quartz-muscovite pegmatite (zone 3, first intermediate zone): Contains cleavelandite, (49 percent), quartz (40 percent), muscovite (10 percent), tantalite-columbite $(<0.5$ percent), tourmaline (trace), and apatite (trace). Average grain size is about 1 inch. The maximum size of recovered muscovite books is 2 inches. One black plate of tantalite-columbite is $\mathbf{0 . 0 2}$ inch thick and 0.75 inch long.

Cleavelandite-quartz-muscovite pegmatite (zone 5, third intermediate zone): Contains cleavelandite $(66$ percent), quartz ( 25 percent); muscovite $(7$ percent), cassiterite $(<0.5$ percent), apatite $(<0.5$ percent), and tourmaline (trace). Individual grains average about 1 inch, but aggregates average 3 inches. The cleavelandite aggregates reach a maximum of 13 inches, and muscovite books 3.5 inches. Very fine muscovite $(0.2$ inch) occurs in several aggregates, 2 to 3.5 inches, between 80.8 and 89.5 feet. Brownish-black grains of cassiterite, 0.05 to 0.9 inch, occur along the boundaries between cleavelandite and muscovite. Bluish-green grains of apatite are mostly 0.05 inch in diameter, but one elongate prismatic grain is 1.1 by 0.2 inches.

Cleavelandite-quartz-muscovite pegmatite (zone 3, first intermediate zone): Contains cleavelandite (45 percent), quartz ( 40 percent), muscovite ( 14 percent), tourmaline $(<0.5$ percent), and apatite (trace). Average grain size is about 1.5 inches. The maximum size of recovered muscovite books is 1.5 inches. Greenish- to bluish-black grains of tourmaline average 0.25 inch.

Albite-quartz-muscovite pegmatite (zone 2 , wall zone): Contains albite (49 percent), quartz (35 percent), muscovite ( 9 percent), perthite ( 5 percent), tourmaline $(0.5$ percent), unknown alteration products of phosphate minerals $(0.5$ percent), garnet $(<0.5$ percent), apatite (trace), and tantalitecolumbite (trace). The grain size varies widely but averages about 0.5 inch. The zone can be subdivided into layers on the basis of mineralogy and texture (see table at end of $\log$ ). Sugary-grained albite occurs in irregular clots, 0.5 to 3 inches; blocky to subplaty albite is in aggregates as large as 2 inches. Flesh-colored grains of perthite range from 0.5 to 3.5 inches and are embayed and veined by albite, quartz, and muscovite. The maximum size of muscovite is 1.5 inches. Bluish-black subhedral grains of tourmaline are 0.25 to 0.5 inch long. One grain of tantalite-columbite is 0.05 inch long and 0.01 inch thick. Pink rounded grains of garnet, ranging in size from less than 0.05 to 0.2 inch, occur from 118.0 to 120.0 feet.

Quartz-muscovite-albite pegmatite (zone 1, border zone): Contains quartz (74 percent), muscovite (15 percent), albite (10 percent), garnet ( 0.5 percent), and apatite (trace). Very fine grained (average 0.15 inch) albite occurs chiefly near 120.0 feet. Reddish rounded grains of garnet are 0.05 inch in size.

\footnotetext{
I Beryl percentages for hole 7 are based on visual estimates. The area of beryl on the core was not measured, as for other holes, because the core recovery in pegmatite
} was only 41 percent and results would not be significant. 
Feet

$120.2-155.8$
Hole 7-Continued

Description

Pegmatite-Continued

Quartz-mica schist: Contains quartz (45-65 percent), muscovite (15-30 percent), biotite (10-25 percent), garnet ( 0.5 percent), and chlorite (trace). Pseudomorphs of muscovite and biotite after euhedral staurolite, 0.05 to $0.5 \mathrm{inch}$, constitute as much as 5 percent of some of the more micaceous beds, but average only about 2 percent. Quartz stringers, 0.05 to 0.25 inch thick, form about 5 percent of the unit.

Angles of intersection of drill core in hole 7 with bedding, schistosity, and pegmatite contacts, in degrees

\begin{tabular}{|c|c|c|c|}
\hline Depth (feet) & Bedding & Schistosity & $\begin{array}{c}\text { Pegmatite } \\
\text { contacts }\end{array}$ \\
\hline $\begin{array}{l}40-55 \\
69 \\
120.2 \\
122 \\
154\end{array}$ & $\begin{array}{r}5 \\
10-25 \\
50\end{array}$ & $\begin{array}{ll}\text { (1) } & \\
& 30 \\
& 10 \\
& 10 \\
\text { (1) } & \\
& 35\end{array}$ & \\
\hline
\end{tabular}

1 Parallel to beds.
Mineralogic composition of layers in zone 2 (wall zone), 113.0-120.0 feet, hole 7

\begin{tabular}{|c|c|c|c|c|c|c|}
\hline \multirow{2}{*}{ Depth (feet) } & \multirow{2}{*}{$\begin{array}{l}\text { Average } \\
\text { grain } \\
\text { size } \\
\text { (inches) }\end{array}$} & \multicolumn{5}{|c|}{ Principal minerals (estimated percent) } \\
\hline & & $\begin{array}{l}\text { Blocky to } \\
\text { platy } \\
\text { albite }\end{array}$ & $\begin{array}{l}\text { Sugary- } \\
\text { grained } \\
\text { albite }\end{array}$ & Quartz & Museovite & Perthite \\
\hline $113.0-114.4$ & $\left\{\begin{array}{l}12 \\
225\end{array}\right.$ & 45 & 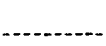 & 25 & 4 & 25 \\
\hline $114.4-120.0 \ldots$ & $\begin{array}{l}3.05 \\
2.4\end{array}$ & 45 & 8 & 35 & 10 & $-\ldots .$. \\
\hline
\end{tabular}




\section{INDEX}

A

Page

Abstract.

Acknowledgments.

Adams, J. W., work cited.

$6,7,8,9,10,20,23,26,27,28,30,31,33$ $34,35,36,37,38,40,41,42,43,44$.

See also Cleavelandite.

Albite-oligoclase

Albite-quartz-muscovite pegmatite, wall zone (zone 2)

See atso Wall zone; Zone 2

Alteration, of country rock................. staurolite

Alteration products of phosphate minerals in pegmatite in drill core $30,31,36,37,38,41,42,43$

Altitude

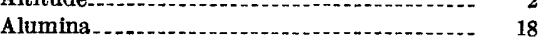

Amblygonite-montebrasite........ $3,6,7,9,10,11,12,18,20,21,23-24,30$, $31,36,37,42$.

Andalusite, in metamorphic rocks.......... 4,5,33 Anorthite content Apatite, in metamorphic rocks. ......... 5, 28, 34, 36

in pegmatite........ $7,8,9,10,12,13,15,17,18,26,27,28$, $30,31,33,34,35,36,37,38,39,41,42$, 43.

Assemblages, mineral.................... 19, 20

Autunite.

Battle Creek.

Bedding, in metamorphic rocks............

Beryl, composition........... 8, 9, 10,11,12,13, 14, 22 content of internal structural units..... 7, 21-23 deposits............... 21, 22 descriptive data ....................... 7 $8,9,10,11,12,13,14,21,22,23,26,30$, $31,32,33,34,35,36,37,38,39,40,41$, $42,43$.

estimated content of Peerless pegmatite... 17 fiuid inclusions grain measurements .................. 21,22 in pegmatite in drill core ................ 26, $30,31,32,33,34,35,36,37,38,39,40$, $41,42,43$. $9,10,11,12,13,14,22,23,26,31,32$, $33,34,35,36,37,38,39,40,42,43$.

production . . . . . reserves...................................... 24 skeletal crystals ("shells")

Biotite, in metamorphic rocks........... $5,19,25,26,27,29,31,33,34,35,36$, $37,41,42,43,44$.

Binyon, Eugene O., and Ferguson, Stuart, work cited... 3,25 Black Hills pegmatites............... . 7, 15, 18, 19, 20

Border zone, layers in ................ $4,6,8$ See also Sequence of layers in border and wall zones.

mineralogic data

minerals in

thickness. $6,7,8$ so Quartz-muscovite-plagioclase pegmatite; Zone 1.
C

Page

Cassiterite $3,6,7,9.10,11,12,13,14,15,21,24$, $28,30,31,33,35,36,37,38,39,41,43$.

Cesium........... 17, 21

Chalcopyrite $. . . . . . .5,6,31,42$

Chemical composition, Peerless pegmatite.. $5,17,18$

Chlorite, in metamorphic rocks.......... 4, 5, 19, $25,26,27,29,33,34,35,39,41,42,43,44$

Chrysoberyl

Cleavelandite _.. 6, 7, 11, 12, 13, 14, 15, 17, 23, 26, $27,28,30,31,34,35,36,37,38,39,41,42$, 43.

Cleavelandite-quartz pegmatite, third intermediate zone (zone 5) ........ 7, 12-14, 16 See also Zone 5.

Cleavelandite-quartz-muscovite pegmatite, first intermediate zone (zone 3) ... 7, 11,

See also Zone 3.

12,16

Convection.. 19,20

Core of pegmatite (zone 7) ........... 6, 7, 14, 15 See also Zone 7.

Country rock. See Metamorphic rocks.

Crystallization, pegmatite ............... 18, 19, 20

Custer district

\section{D}

Dahllite $\quad 7,9,10,11,12,31$ Diamond-drill holes, logs . . .................. 25-44 Dikelike apophyses ........ 6, 19 Drusy structure, fracture fillings............... $\quad 17$ Dumps. See mine dumps.

Dunton, P. J. and Havens, R. G., spectrographic analysis by

$\mathbf{E}$

Edison pegmatite deposit

Etta pegmatite deposit

\section{F}

Faults

Feldspar. See potash feldspar, soda feldspar.

Ferguson, Stuart and Binyon, Eugene O., work

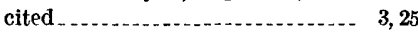
Fluid inclusions. See Beryl, fuid inclusions.

Fractional crystallization, factor in origin..... 18

Fracture-filling units..................... 6, 8, 14,17 See also Fracture fillings.

Fracture fillings_..._.... 5, 6, 8, 10, 14, 15, 17, 19, 20, 31

Fractures, control of intrusion by ............ 5,19

\section{G}

Garnet, in metamorphic rocks. ........... 4, 5, 25, $26,27,29,33,34,35,37,41,42,43,44$ in pegmatite............... $6,7,8,9,10,11$, $12,26,27,30,34,37,38,41,42,43$

Genesis. See Peerless pegmatite, origin.

Granite, Harney Peak

Grizzly Bear Creek

Gude, A. J., 3d, X-ray work cited..... 9, 10, 15, 31

H

Hall, W."E., 'and"Stoll, W. C., work cited.... 3 Hamilton, J."C., spectrographic analyses by .- 16 Harney Peak .................... 1,2 Harney Peak granite

Harney Peak Tin Mining, Milling, and Manufacturing $\mathrm{Co}$
Havens, R. G., and Dunton, P. J., spectro-

graphic analysis by ............ 15, 16

Page Herringbone structure, muscovite........ 11 ,

Hill City district.

$12,13,14,21,30$

Hugo pegmatite deposit.

Hydrothermal, materials. solutions

$\mathbf{I}$

Indices of refraction. See Optical data.

Intermediate zone, first (zone 3) ......... 4, 11, 21, 24 See also Zone 3.

second (zone 4) ...................... 11, 12, 22

See also Zone 4.

third (zone 5)

See also Zone 5.

fourth (zones $6 \mathrm{a}$ and $6 \mathrm{~b}$ ) ................... 14

See also Zone 6a; Zone 6b.

Internal structure.

units, pegmatite. See Peerless pegmatite, internal units.

\section{$\mathbf{K}$}

Keel of pegmatite limbs

Keystone...

(1,

1,2

pegmatites............................. 20

Keystone Feldspar and Chemical Co........ 2, 3,4

Lang, A. J., Jr., and Thurston, W. R., work cited.................................

Layers in zone 2 (wall zone) _. 26, 27, 29, 32, 35, 40, 44

See also Sequence of layers in border and wall zones.

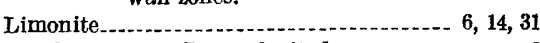

Lindberg, Marie L., work cited...............

Lithia mica $5,6,7,14,15,16,17,18,21,24,31$

Lithia mica-cleavelandite pegmatite (zone 7 ,

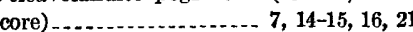

Lithia mica-cleavelandite-quartz pegmatite, replacement unit................ 13-15 Lithiophilite-triphylite group
$9,10,11,12,13,14,24,38$

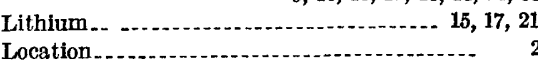

Loellingite(?) $\ldots . . . . .6,7,9,11,12,26,30,31,38,42$

Logs, U. S. Bureau of Mines diamond-drill

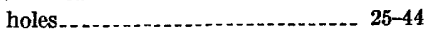

M

Magnesium......... 17 Manganese................. 17

Metacrysts.......... 4, 25, 27, 33, 35, 36, 41, 43

$\begin{array}{lr}\text { Metamorphic rocks } & \\ \text { Metasomatic replacement. } & 19\end{array}$

Mica, deposits of ........................... 21

in metamorphic rocks

lithia. See Lithia mica.

production of Peerless pegmatite.........

reserves................................... 24

scrap. See Scrap mica.

spectrographic analyses................... 16

Micaceous quartzite

Microcline_............................. 14, 17, 22, 23

Microcline-perthite................. 6, 7

See also Perthite. mineralogy

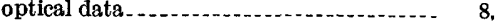
See also Zone 1.

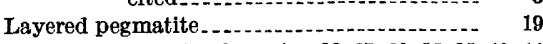

punch and sheet...................... 2, 3, 21 9

Boron......................................... 17 


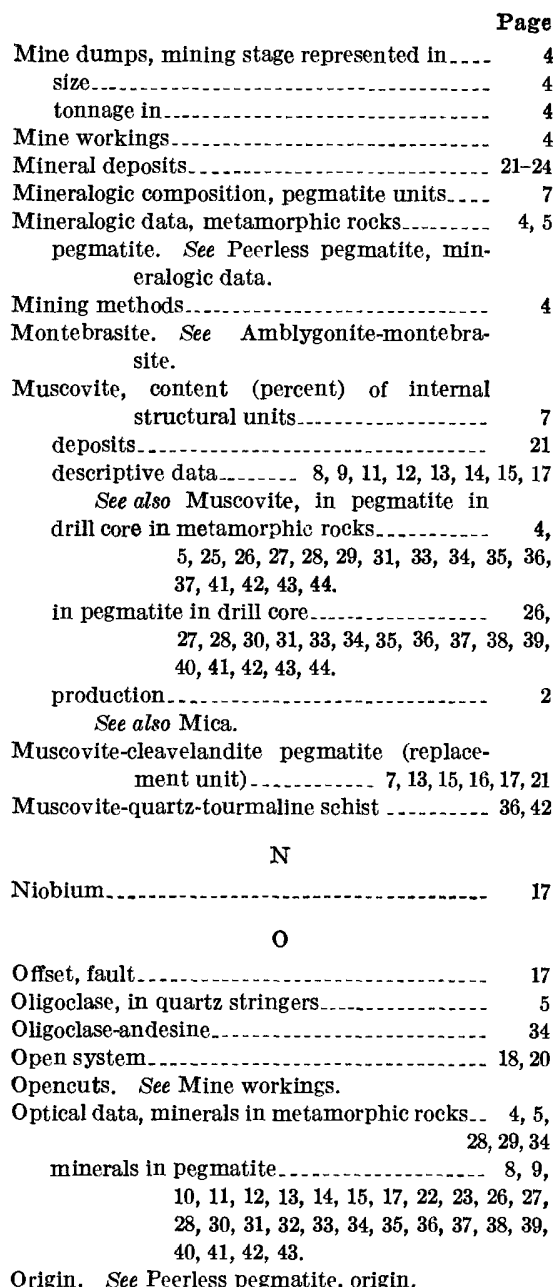

Origin. See Peerless pegmatite, origin.

Overburden .......................... 25, 27, 29, 33, 35

Page, L. R., work cited

Peerless mine

Peerless pegmatite, chemical composition _.... 17-18 faults............ 17 internal units.......................... 6-17 $\operatorname{logs}$ of U. S. Bureau of Mines diamonddrill holes. . . . . .

mineral deposits...................... 21-24 mineralogic data................ 5-15, 17, 26-44 origin .............. 18-21

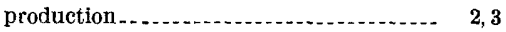
reserves............................. 24 size, shape, and structure.............. 5,6 variation in mica composition ............ 17 Pegmatitic fluid........... 18, 19, 20 Perthite-_. 5,8 , $9,10,11,12,13,17,19,22,23,26,28$, $30,31,34,35,37,38,39,40,43,44$.

See also Microcline perthite.

Perthite-cleavelandite-quartz pegmatite, second intermediate zone (zone 4) ... 7, 11,

See also Zone 4

$12,13,16$

Phosphate minerals $10,11,12,13,14,15,24,31,38,42$

Pinnacle, unmined....................... 17 Plagioclase, anorthite content in border zone .. 8 in pegmatite ................ $5,7,8,17,18,29,34$ See also Albite; Albite-oligoclase;

Cleav e landite; Soda feldspar.

in quartz stringers.

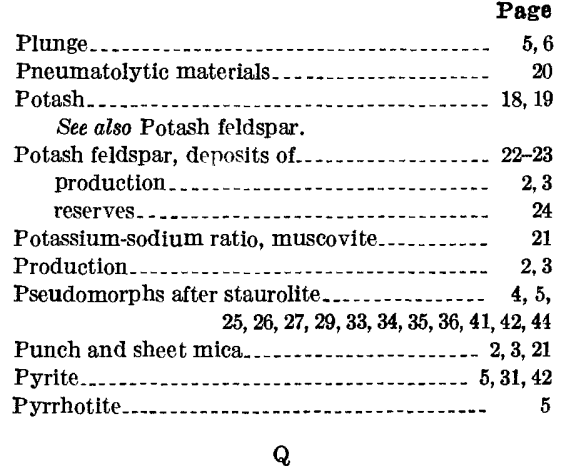

Quartz, in metamorphic rocks ...... 4, 5, 25, 26, 27, $28,29,33,34,35,36,37,39,41,42,43,44$

in pegmatite $8,9,10,11,12,13,14,15,17,18,19,20$, $23,26,27,28,29,30,31,33,34,35,36$, $37,38,39,40,41,42,43,44$.

in quartz stringers. See also Quartz stringers.

vein .............................. 39

Quartz-mica schist. .................... 4, 5, 25,

$26,29,31,33,34,35,37,39,40,42,43,44$

Quartz-mica-chlorite schist................. 5 ,

$25,26,27,29,33,34,35,39,41,43$

Quartz-mica-staurolite schist............. 4-5, 27, 33 Quartz-mica tourmaline schist_........ 29, 33, 34, 36 Quartz-microcline pegmatite, fourth intermediate zone (zone 6a) ........... 7,14

See also Zone 6a.

Quartz-muscovite-plagioclase pegmatite border zone (zone 1) .................. 7,8,16

See also Border zone; Zone 1.

Quartz-muscovite schist.................... 27 See also Quartz-miza schist.

Quartz-muscovite-tourmaline schist ........ 5, 28, 37 See also Quartz-mica-tourmaline schist.

Quartz pegmatite, fourth intermediate zone (zone $6 \mathrm{~b}$ ), fracture fillings....... 7, 14, 17

See also Zone $6 \mathrm{~b}$.

Quartz-plagioclase-muscovite pegmatite, undifferentiated.................. 5

Quartz plagioclase pegmatite ... . Quartz stringers, in schist................ 5 , $25,26,27,28,29,31,33,34,36,39,42$, 43,44

Quartzite. See Micaceous quartzite.

$\mathrm{R}$

Ratio of potassium and sodium in muscovite.. Reaction between crystals and rest-liquid.-..- $\quad 20$

Redden, J. A., work cited

Reinbold Metallurgical Co........................

Relicts, of staurolite and andalusite........ of zones in replacement units

Replacement processes...................... 18 textures.............. 20 units .................... $5,6,7,8,14,15,20,24$ See also Lithia mica-cleavelanditequartz pegmatite; Muscovitecleavelandite pegmatite.

Reserves Restricted system. ............. 18, 20 Roadifer, R. E., work cited._. Rolls, structural ......................... 6,9 Rubidium _.............................. 17, Ruled muscovite ..................... 11, 13, 21,30 s

Schaller, W. T, cited 8,23 Schistosity....................... 5,19 Scrap mica ................. 2, 2 See also Muscovite; Mica. Segments of Peerless pegmatite............ 6, 6
Page

Segregation of fluids....................... 10 Sequence, of internal units in Peerless pegma. tite of layers in border and wall zones.... 4, $4,10,19$ Shape of Peerless pegmatite...... 5,6 Silica............... 18

Size of Peerless pegmatite of minerals in metamorphic rocks........ 4,5 of minerals in pegmatite.............. 5 $10,11,12,13,14,15,17,22,23,2$

Slickensided fault surfaces................. 17, 20

Soda See also Soda feldspar.

Soda feldspar, deposits of

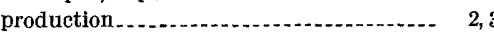
reserves.................................. 2

Spectrographic analyses, mica............... 16

Spodumene................................. 74

Stannite

Staurolite in metamorphic rocks............ 4

$5,19,25,27,29,33,35,42$

See also Pseudomorphs after staurolite.

Stoll, W. C., and Hall, W. E., work cited....

Structural layers................................ 7

Structure of Peerless pegmatite......... 5,6

Struverite ............. 7

Sugary-grained aggregates, in wall zone $\ldots . . . .10$

$19,22,31,34,36,37,38,41,43$

pegmatite.

Svan bergite $\ldots . . . . .7,9,11$

Tantalite-columbite

$3,6,7,8,9,10,11,12,13,14,15,17,21$

$24,26,27,28,30,31,34,36,37,38,41$, 42,43 .

Temperature range, in primary fluid inclusions.

Temperatures, crystallization.

Textural terms, classification

Thurston, W. R., and Lang, A. J., Jr., work cited - .

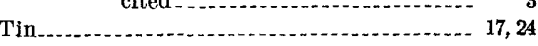

Torbernite

Tourmaline, in metamorphic rocks ........ 5 , $27,28,29,33,34,36,37,39,42$

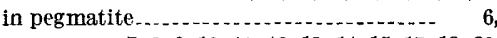
$7,8,9,10,11,12,13,14,15,17,18,20$ $26,27,28,30,31,33,34,35,36,37,38$, $39,40,41,42,43$.

Tourmaline-quartz pegmatite $\quad 7,17$ Triploidite(?) _........ 7, 9, 10, 31

U

U. s. Mica Co., Chicago, Ill Underground workings, See Mine workings.

V

Vivianite(?)

Volatile materials _..... 19,20 Vugs, in pegmatite........

\section{W}

Walker, A. F., cited ........ 3,24

Wall zone, beryl in ...................... 10, 21, 22

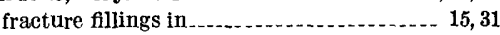
grain size of minerals in

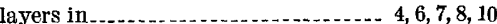
mineral deposits in ............. 21, 22, 23, 24 mineralogic composition.............. 6,9 data........ $9-11$ sequence of layers in .................. 4, 8,9,19 texture................................ 9

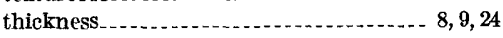
See also Albite-quartz-muscavite pegmatite; Zone 2.

\section{,}

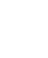

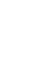


Page

Water.

$5,18,19$

Wedge structure, muscovite ......... 11, 12, 13, 14, 21

White Cap pegmatite deposit................

Zonal sequence of Black Hills pegmatites....

19

Zones:

1, quartz-muscovite-plagioclase pegmatite

(border zone) ......... 7, 8, 16, 18, 21, 23, 24

border zone, in diamond-drill holes... 26 , $27,28,30,31,33,34,36,37,38,39,41$, 42,43

\section{Zones-Continued}

, albite-quartz-muscovite pegmatite (wall

zone) .............. 7-11, 18, 21, 22, 23, 24

wall zone, in diamond-drill holes ....- 26 $27,28,30,31,33,34,36,37,38,41,42$, 43.

3, cleavelandite-quartz-muscovite pegmatite (first intermediate zone) -.... 6 ,

first intermediate zone, in diamonddrill holes . . . . . . . . . . ........... 26 $27,28,30,31,34,36,37,38,39,41,42,43$

4, pertbite-cleavelandite-quartz pegmatite (second intermediate zone) ....... 6 $7,11-12,13,16,18,21,22,23,2$ second intermediate zone, in diamonddrill hole
Zones-Continued Page
5, cleavelandite-quartz pegmatite (third
intermediate zone) $7,12-14,16,18,21,22,23,24$
third intermediate zone, in diamond- drill holes . ................... 26

6a, quartz-microcline pegmatite (fourth intermediate zone) ....... 7, 14, 22, 23. 24

$6 \mathrm{~b}$, quartz pegmatite (fourth intermediate zone) ..................... 7, 14, 27, 35, 39 fourth intermediate zone, in diamond drill holes. ..................... 27, 35, 39

7. lithia mica-cleavelandite pegmatite (core) $\ldots \ldots \ldots \ldots . . . . . .7,14-15,16,18,21,24$ 